\title{
THE EFFECT OF ROADS ON SMALL MAMMAL MOVEMENT
}

\author{
By
}

Rachelle McGregor

\author{
A thesis submitted to \\ the Faculty of Graduate Studies and Research \\ in partial fulfillment of \\ the requirements for the degree of \\ Masters of Science
}

Department of Biology

Carleton University

Ottawa, Ontario

January, 2004

(C), Rachelle L. McGregor 


\author{
National Library \\ of Canada \\ Acquisitions and \\ Bibliographic Services \\ 395 Wellington Street \\ Ottawa ON K1A ON4 \\ Canada
}

Bibliothèque nationale

du Canada

Acquisisitons et services bibliographiques

395 , rue Wellington Ottawa ON K1A ON4 Canada
Your file Votre référence ISBN: 0-612-89855-5

Ourfile Notre référence ISBN: 0-612-89855-5
The author has granted a nonexclusive licence allowing the National Library of Canada to reproduce, loan, distribute or sell copies of this thesis in microform, paper or electronic formats.

The author retains ownership of the copyright in this thesis. Neither the thesis nor substantial extracts from it may be printed or otherwise reproduced without the author's permission.
L'auteur a accordé une licence non exclusive permettant à la Bibliothèque nationale du Canada de reproduire, prêter, distribuer ou vendre des copies de cette thèse sous la forme de microfiche/film, de reproduction sur papier ou sur format électronique.

L'auteur conserve la propriété du droit d'auteur qui protège cette thèse. $\mathrm{Ni}$ la thèse ni des extraits substantiels de celle-ci ne doivent être imprimés ou aturement reproduits sans son autorisation.
In compliance with the Canadian Privacy Act some supporting forms may have been removed from this dissertation.

While these forms may be included in the document page count, their removal does not represent any loss of content from the dissertation.
Conformément à la loi canadienne sur la protection de la vie privée, quelques formulaires secondaires ont été enlevés de ce manuscrit.

Bien que ces formulaires aient inclus dans la pagination, il n'y aura aucun contenu manquant. 


\begin{abstract}
Barriers such as roads may decrease small mammal movement between patches in fragmented landscapes, which may decrease the likelihood that extinct patches will be recolonized by dispersing individuals. We hypothesized that there are three possible barrier effects of roads: aversion to roadside habitat due to increased noise or pollution levels associated with traffic volume, avoidance of the road itself, or increased probably of mortality due to collisions with vehicles. We evaluated the type of barrier effects that roads have on small mammal (white-footed mice and eastern chipmunks) movement using a combination of mark-recapture and translocation studies. We did not find that small mammals avoid roadside habitat or that they experience higher levels of mortality associated with traffic volume. Our results suggest that small mammal movement decreases because they avoided crossing the roads during short and long distance movements through the landscape.
\end{abstract}




\section{ACKNOWLEDGEMENTS}

Thank you, Lenore, for your guidance, your patience and your knack for cutting through it all. I'd like to think that I've taught you 1/32 as much as you have taught me, even if it was the finer details of mullets.

I would also like to thank my committee members, Jayne Yack and Antoine Morin.

Thanks to Kathy Lindsay for additional funding for my fieldwork. Lenore never lets me forget that I was the most expensive Master's field work that she had ever funded, and Kathy's additional funds took the pressure off Lenore's grant. I would like to thank Dave Omond as well for his help in the preparation of my field work, and Kringen Henein whose knowledge of furry little creatures was a real help as I began my field research so long ago.

A special note on the S'mammal Posse, both honorary and paid. Phil, Sarah, Shawna, Penny and Tara, I really appreciate all the work that you put into my project. I am sure I learned more about being a good supervisor and boss than you learned fieldwork. I hope that you look back on your time in the field as a good experience and are keen ecologists because of it. Thanks to the honorary S'mammal Posse member, Jochen, for volunteering to come out to be around chipmunks and mice before they were roadkill.

Everyone knows how much I like to see my name in print, and I think I should return the favour to some members of the LE-lab. Rebecca, you were a great help to me when I needed someone to look at my data, again. Stephanie, the one who would understand my need to procrastinate and get away from the thesis, thanks for being a pair of ears to my complaints. Krista, thanks for you suggestions for my thesis and for being my willing dancing compatriot. Julie, I appreciate your friendship and the help you've provided along the whole way. 
Thank you to Bemie and Miles, two little creatures that were integral to the pre-field season tests on fluorescent powder, and who became a part of my family shortly thereafter. They could brighten up my day like no one else, and I am sure my thesis would not be the same without them.

Thanks for the support from my family. While it may be difficult to explain exactly what I was doing all this time, I know that you were proud that I was doing it. I hope that I'll be making money doing it in the near future!

One last thank you is appropriate. Shawn, thank you for being so supportive during this past 2 years, and for being an even bigger distraction than Bernie and Miles. You were my biggest support and critic, and an inspiration for me to be as good a scientist and you are and will be. Thank you for putting up with my eccentricities throughout this whole ordeal. 


\section{TABLE OF CONTENTS}

ABSTRACT

ACKNOWLEDGEMENTS.............................................................IV

TABLE OF CONTENTS........

LIST OF TABLES ...

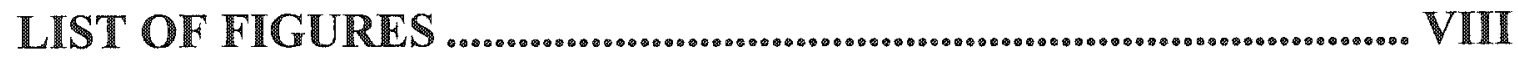

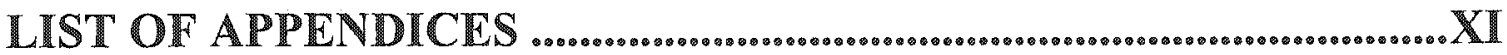

INTRODUCTION

METHODS ...

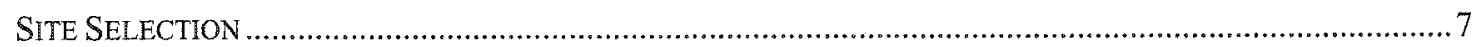

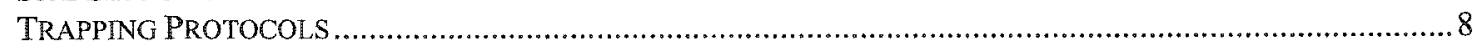

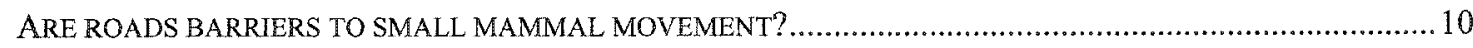

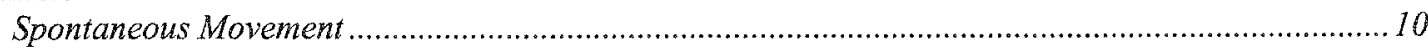

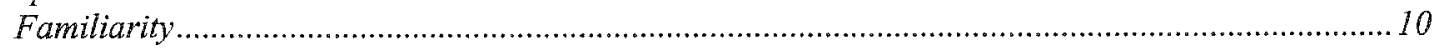

WHAT TYPE OF BARRIER EFFECT DO ROADS EXERT ON SMALL MAMMALS? ........................................12

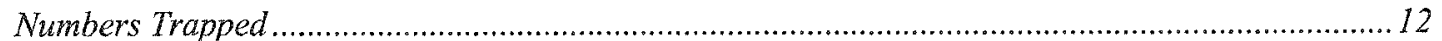

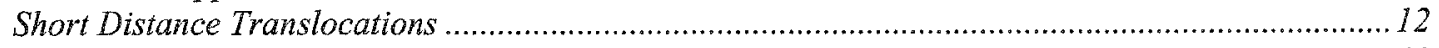

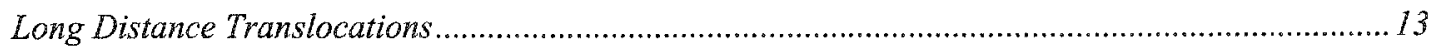

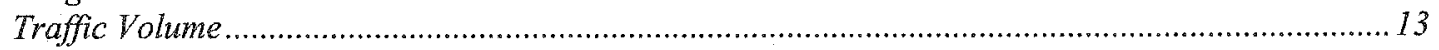

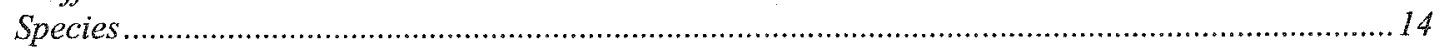

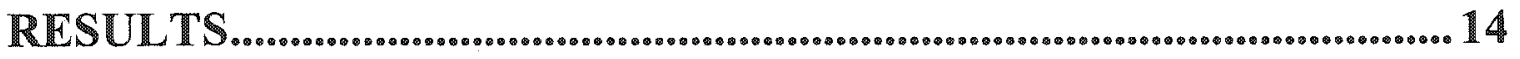

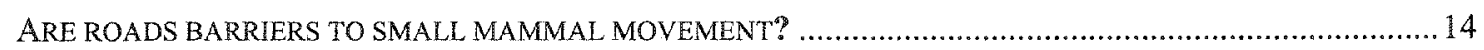

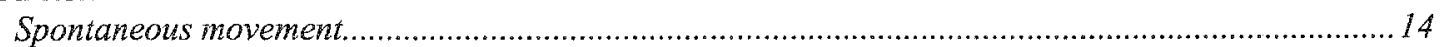

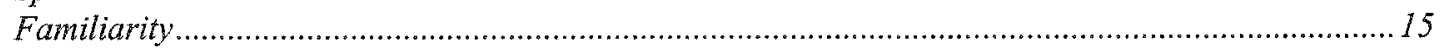

WHAT TYPE OF BARRIER EFFECT DO ROADS EXERT ON SMALL MAMMALS? ...........................................15

Number Trapped

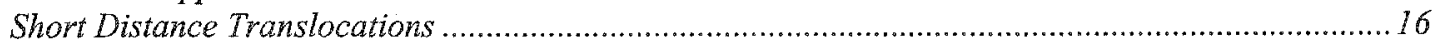

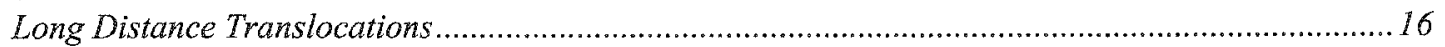

DISCUSSIION _...

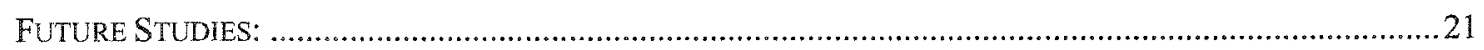

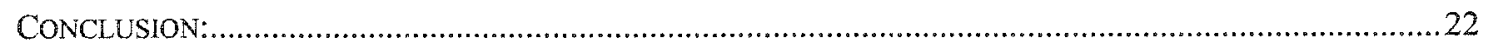

REFERENCES $\ldots \ldots \ldots$ a 


\section{LIST OF TABLES}

Table 1. Questions, hypotheses, predictions and tests used to examine the effect of roads on small mammal movement.

Table 2. Summary of trapping protocols. In both experiments, the grids were trapped for 6 consecutive nights ( 7 days). Twenty of the 24 sites that used trapping protocol three were trapped by Bender in summer 2000.

Table 3. ANOVA table for the simple linear regression of the effect of traffic volume on number of animals trapped $\left(R^{2}=0.095\right)$. Number trapped is the sum of the individuals trapped at all three trapping grids at each site using protocol 1 (Table 2 , Figure 2).

Table 4. ANOVA table for the simple linear regression of effect of traffic volume on the number of mice trapped for each site $\left(R^{2}=0.0031\right)$. Number trapped is the sum of the individuals trapped at all three trapping grids at each site using protocol 1 (Table 2, Figure 2).

Table 5. ANOVA table for the simple linear regression performed of effect of traffic on the number of chipmunks trapped for each site $\left(R^{2}=0.17\right)$. Number trapped is the sum of the individuals trapped at all three trapping grids at each site using protocol 1

(Table 2, Figure 2).

Table 6. ANOVA table for the multiple logistic regression of effect of traffic volume, species and the interaction between traffic and species on the movement success of small mammal translocated short distances using trapping protocol two (Table 2, Figure 3).

Table 7. ANOVA table for the stepwise multiple regression of effect traffic, interpatch distance and the number of roads between patches on small mammal return rates from long distance translocations using trapping protocol three (Table 2, Figure 3). Interpatch distance refers to the edge-edge distance between home and destination patches, traffic volume is the sum of the average annual daily traffic levels on each of the intervening roads between home and destination patches. 


\section{LIST OF FIGURES}

Figure 1. Three possible road barrier effects. a) Avoidance of roadside habitat due to increased pollution and noise levels associated with traffic volume. b) Avoidance of the road surface c) Animals attempt to cross roads but experience higher levels of mortality associated with traffic volume.

Figure 2. Depiction of trapping protocol one. The distance between Roadside grids 1 and 2 is approximately the same distance as between Roadside 1 and Interior grids. Each grid was composed of 6 transects with 6 traps in each, resulting in a 6 by 6 trapping grid. Intertrap and intertransect distance was $10 \mathrm{~m}$. Every site $(n=13)$ included a $100 \mathrm{~m}$ segment of a two lane paved road with no culverts, lights, driveways or access roads along its length. Sites were chosen to cover a wide range of traffic volumes, from 50 average annual daily traffic (AADT) to 15433 AADT. 32

Figure 3. Depiction of trapping protocol two, used for short distance translocations. White-footed mice and eastern chipmunks were translocated an average of $35 \mathrm{~m}$ from the edge of the grid either across the road or farther into the forest. The grids were composed of 6 transects each of which contained 6 traps separated by $10 \mathrm{~m}$. Every site $(\mathrm{n}=15)$ included a $100 \mathrm{~m}$ segment of a 2 lane paved road that did not have culverts, lights, driveways or access roads along its length. Sites were chosen to cover a wide range od traffic volumes, from 50 average annual daily traffic (AADT) to 15433 AADT.

Figure 4. Depiction of hypothetical landscape with "home" patch for trapping protocol three. Four transects of 18 traps were set up in a home patch. White-footed mice and chipmunks were translocated from 20 home patches in 2000 and 4 home patches in 2003 to destination patches in the landscape across varying interpatch distances $(0-1325 \mathrm{~m})$, numbers of intervening roads $(0-4)$ and traffic volumes $(0-15433$ AADT).

Figure 5. White-footed mouse covered with fluorescent powder.

Figure 6. Hypothetical paths of animals translocated within continuous forest and across roads. The mean bearing is calculated using the headings marked off in the path. We expected that animals would have a desire to return to their home range, and so should be oriented back towards the grid. Therefore, the expected relative heading for animals translocated across roads was 180 degrees while the expected relative heading for animals translocated on the same side of the road was 360 degrees.... 34

Figure 7. Comparison of the number of animals that spontaneously moved across roads and within continuous forest. Of the 240 total small mammals trapped, 41 moved between grids. The proportion of animals that moved between roadside grids 
(5/177) was significantly less than the proportion that moved between grids on the same side of the road $\left(36 / 188 ; \mathrm{df}=1, \chi^{2}=24.4, \mathrm{p}<0.0001\right)$. Each of the 13 sites used in this portion of the study was live-trapped for 6 nights.

Figure 8 . The paths of 4 mice and 8 chipmunks that were translocated across roads, and 6 mice and 7 chipmunks that were translocated within the continuous forest patch from 15 sites. Chipmunks are notated by a light grey line, mice by a black line. Stars represent the release point. Paths do not start directly from the stars because the first $5 \mathrm{~m}$ of the paths were removed from analysis.

Figure 9. Comparison of the mean linearity for the paths of white-footed mice and eastern chipmunks that were trapped during protocol two ( $\pm \mathrm{st}$. error). We analysed the paths of 4 mice and 8 chipmunks that were translocated across roads, and 6 mice and 7 chipmunks that were translocated within the continuous forest patch. Both species of small mammals moved across roads had significantly straighter paths than did those translocated within continuous forests when analysed separately (mice: $t=$ $1.28, \mathrm{df}=8, \mathrm{p}=0.11$; chipmunks: $\mathrm{t}=2.31, \mathrm{df}=13, \mathrm{p}=0.02)$ and combined $(\mathrm{t}=2.8$, $\mathrm{df}=23, \mathrm{p}=0.005$ ). 37

Figure 10. Comparison of the mean length of paths for powdered mice and chipmunks translocated across roads and within continuous forest ( \pm st. error). We analysed the paths of 4 mice and 8 chipmunks that were translocated across roads, and 6 mice and 7 chipmunks that were translocated within the continuous forest patch. There was no difference in the length of the paths of animals translocated across roads and continuous forests $(t=1.04, d f=23, p=0.15)$, regardless of species (i.e., chipmunks: $\mathrm{t}=0.82, \mathrm{df}=13, \mathrm{p}=0.21$, mice: $\mathrm{t}=0.15, \mathrm{df}=8, \mathrm{p}=0.44$ ). 37

Figure 11. Mean bearings of animals translocated across the roads and within continuous forest. We expected animals to orient to their home range after translocation, and so expected animals to orient themselves relative to the trapping grid. We arbitrarily chose 180 degrees for animals translocated across the roads and 360 degrees for animals translocated within continuous forest because of the opposite nature of the translocations (see Figure 6). White circles are mean bearings for mice, blue are the mean bearings for chipmunks. There was no significant difference in the orientations $(\mathrm{d} f=23, \mathrm{t}=1.10, \mathrm{p}=0.28)$.

Figure 12. Comparison of the number of individuals trapped in roadside and interior grids ( \pm st. error). We compared the number of animals that were captured in the roadside grids and grids farther away from the road for the 13 sites of protocol one using paired t-tests. There was no significant effect of grid location on the number of animals captured, regardless of site (Figure 12; $\mathrm{t}=1.79, \mathrm{df}=12, \mathrm{p}=0.099$ ), although roadside grids tended to have higher capture rates (6.61 0.14 individuals) than forest interior grids ( $5.3 \pm 0.13$ individuals). 
Figure 13. The effect of traffic volume (annual average daily traffic) on the number of mice and chipmunks trapped. There was no effect of traffic volume on the number of animals trapped in the sites $\left(F_{1,12}=1.16, p=0.30\right)$, even when chipmunks $\left(F_{1,12}=\right.$ $2.32, p=0.16)$ and white-footed mice $\left(F_{1,12}=0.034, p=0.86\right)$ were analysed separately.

Figure 14. Comparison in the number of animals that were recaptured when translocated across roads and within continuous forest. Ninety one animals were translocated from 15 sites. Although over $53 \%$ of animals translocated across roads successfully returned from translocation, movement success was significantly higher when animals were translocated within continuous forest $\left(\chi^{2}=7.28, p=0.0070\right)$ than across roads.

Figure 15. The effect of the number of roads between home and destination patches on the number of animals recaptured from long distance translocations in protocol three. We translocated 312 small mammals from 24 home patches to destination forest patches over varying numbers of intervening roads. The proportion of returning individuals from translocations decreased by about 50 percent for every road than was placed between two forest patches. There was a significant, negative effect of intervening roads on small mammal movement success $\left(\mathrm{df}=1\right.$, Wald $\chi^{2}=$ $14.88, \mathrm{p}<0.0001$ ). 


\section{LIST OF APPENDICES}

Appendix A. Data for trapping protocol one. Locations are names of sites used in the summers of 2002 and 2003. Dates are for the first time that an individual was trapped. Traffic volumes are annual average daily traffic (AADT) volumes as estimated by the City of Ottawa (2002). ME: Mustela erminae, MP: Microtus pennsylvanicus, PL: Peromyscus leucopus, TH: Tamiascurius hudsonicus, TS: Tamias scurius, CG: Clethrionomys gapperi, SF: Sorex fumeus, NI: Napaeozapus insignis, GS: Glaucomys sabrinus, SC, Sciurus carolinensis, SC: Sorex cinerex. Unmarked individuals trapped on the final day at each site were not marked and are labelled as $\mathrm{nm}$ in the table. Recaptured indicates the individual was recaptured at least one more time the 6 nights of a trapping session. Where indicates what direction an animal moved: within the continuous forest or across roads

Appendix B. Data for trapping protocol two. Locations are names of sites used in 2002 and 2003. Traffic volume is average annual daily traffic volumes. Individuals received a unique tag number. Animals were translocated either across roads (AR) or within the patch (WP). Animals that were recaptured within the 6 night trapping session for each site were recorded as returning.Ts: Tamias scurius, PL: Peromyscus leucopus.

Appendix C. Data for trapping protocol three. Traffic volume is the sum of the AADT for each of the roads that are between the home and destination patches. Edge-to-edge distance was measured between home and destination sites using a GIS based application or field marking tape. Individuals were marked with a unique tag. Animals that were recaptured within the 6 night trappng session for each site were recorded as returned. PL: Peromyscus leucopus, TS: Tamias striatus

Appendix D. Sample data manipulation for mean heading. 


\section{INTRODUCTION}

The ability of animals to move through a landscape to recolonize habitat patches is important for overall population persistence (Fahrig and Merriam 1985; Kozakiewicz 1993). Roads can act as barriers to such movements, the degree to which will depend on the behavioural responses of the animals, as well as attributes of the road and traffic volume. Roads can act as barriers to animal movement in three ways (Figure 1). First, animals may avoid roadside habitat due to traffic emissions such as noise or pollution. This will tend to keep the animals away from the road, limiting movements across it. For example, Reijnen and Foppen (1994) showed that forest-dwelling birds were negatively associated with roadside edge habitat, due to increased noise and predation levels, even when the birds were categorized as edge nesters. Larger animals such as martens (Robitaille and Aubry 2000), wild reindeer (Nellemann et al. 2001) and wolves (Thiel 1985) also preferentially select habitat away from roads. For animals that avoid roadside habitat due to traffic emissions, the degree to which roads act as a barrier will depend on the traffic volume on the road.

The second situation in which roads can act as barriers to animal movement is when animals show an aversion to the road surface itself, and therefore may not attempt to cross the road (Figure 1). Such animals use habitat up to the road edge but do not attempt to cross roads during either foraging (Mader 1984; deMaynadier and Hunter 2000) or dispersal (Keller and Largiader 2003) movements. For example, roads act as linear barriers to movement for many species of ground beetles, significantly reducing gene flow and genetic variability (Mader et al. 1990; Keller and Largiader 2003). Develey and Stouffer (2001) showed that roads created linear boundaries to movements 
by understory birds in mixed-species flocks. These birds moved within a few meters of open roads but avoided crossing even when provoked through antagonistic calls. Although road verges are desired foraging habitat for species such as hedgehogs or badgers, these species do not cross roads at a rate that is expected if roads did not act as barriers to movement (Clarke et al. 1998; Rondinini and Doncaster 2002).

The third way in which roads can act as barriers is in situations where animals attempt to cross the road but the probability of successfully crossing the road without being killed by a vehicle is low (Munguira and Thomas 1992). In this case, the road acts as a barrier as well as a source of mortality (Figure 1). For example, Hels and Buchwald (2001) showed that 34 to $98 \%$ of anurans that attempted to cross roads were killed, representing approximately $10 \%$ of the overall population. Ashley and Robinson (1996) censused wildlife mortality over two years along a $3.6 \mathrm{~km}$ section of a two-laned paved highway and found 32,000 dead individuals including amphibians, reptiles, mammals and birds. Lode (2000) found that traffic exponentially increased mortality for many endangered species.

The purpose of my study was to determine whether and how roads affect small mammal movement. Small mammal populations are often subject to within-year extinctions and recolonizations (Merriam and Wegner 1992), and movement is necessary to ensure that regional populations persist (Middleton and Merriam 1981; Krohne 1997; Krohne and Hoch 1999). Existing studies suggest that roads decrease the ability of small mammals to move through the landscape(Mader 1984; Goosem 2001). Oxley et al. (1974) showed that although small mammals were capable of crossing roads, road clearance significantly negatively affected small mammal movement. Mader (1984) 
showed that woodland mice adjust the edges of their territories to roads and that they rarely crossed. Goosem (2001) showed that crossing of $12 \mathrm{~m}$ to $20 \mathrm{~m}$ wide roads by small mammals was partially to severely inhibited, depending on the behaviour of the species. Taken together, these studies suggest that roads act as partial to complete barriers to small mammal movement.

Given that roads are barriers, what type of barrier effect do roads exert on small mammals? Overall, roads do not appear to decrease small mammal densities in forests that are delineated by roads (Garland and Bradley 1984; Rondinini and Doncaster 2002), and may in fact create additional habitat suitable for more generalist species (Adams and Geis 1983). This suggests that small mammals do not avoid roadside habitat due to traffic emissions. Since it is unlikely that small mammals are avoiding available roadside habitat, is the decreased movement across roads due aversion to the road surface itself or to traffic mortality? The existing literature does not provide a clear answer to this question. While some studies have shown little movement across roads (Oxley et al. 1974; Clark et al. 2001; Rondinini and Doncaster 2002), others show that some species readily attempt to cross roads (Goosem 2001) and experience high traffic mortality (Adams and Geis 1983; Lode 2000). If small mammals experience mortality on roads, we would expect higher mortality with higher traffic volume, which should result in lower movement success.

Are the road barrier effects different for different small mammal species? Interspecific differences in movement patterns due to roads can be attributed to behavioural phenomena (Ims 1995). For example, forest specialists may be reluctant to move across a road because they are unwilling to leave cover (Henein et al. 1998). On the 
other hand, habitat generalists are capable of moving through and living in many types of habitats, and may not be as strongly influenced by unfamiliar cover types (Vestal and Hellack 1977). Finally, traffic volume, and the mortality associated with that volume, should affect diumal species more strongly than nocturnal species since most traffic occurs during daylight hours (City of Ottawa, pers. comm.).

We chose to focus my study on eastern chipmunks (Tamias striatus) and whitefooted mice (Peromyscus leucopus) because although both are woodland species, they are differentially distributed across habitat types (Seamon and Adler 1996b). Chipmunks are territorial, diurnal forest specialists (Henein et al. 1998; Dunford 1970; Getty 1981 b; Bowers 1995). White-footed mice, on the other hand, are rarely territorial, are nocturnal, and are capable of living and moving through several types of habitats (Vestal and Hellack 1977; Nadeau et al. 1981; Halama and Dueser 1994). White-footed mice typically have higher densities in edge habitat (Anderson et al. 2003a), while eastern chipmunks show no preference for edge or interior habitat so long as there is ample canopy cover (Getty 1981b). With respect to road aversion, since white-footed mice are a generalist species, they may be more likely to move across roads during regular movements than the forest-specialist chipmunks who may avoid the road surface. We also expected eastern chipmunks would be more sensitive to traffic volume since they are a diurnal species. Therefore, they may experience higher mortality than white-footed mice.

\section{Predictions}

The questions, hypotheses and predictions are summarized in Table 1. Question One: Are roads barriers to small mammal home range movement? 
Based on existing literature, we hypothesized that roads are barriers to small mammal movement and predicted that small mammals would not move across roads at the same rate as they do within continuous forest. We also hypothesized that if roads are barriers to movement, small mammals should not be familiar with habitats across roads from where they normally occur. Small mammals that are moved to unfamiliar habitat tend to choose different paths than those moved within their home range (Clarke et al. 1993). For example, eastern chipmunks moved $100 \mathrm{~m}$ from their burrow entrance showed significantly longer paths to refugia than those moved $10 \mathrm{~m}$ from their burrow (Clarke et al. 1993). Additionally, small mammals moved to unfamiliar territories tend to move in straight lines but make u-turns if they do not encounter familiar visual cues (Bovet 1968; Thibault and Bovet 1999). Small mammals moved far outside their home ranges are not capable of orienting themselves back to their home range (Jamon and Benhamou 1989), even if they eventually return (Zollner and Lima 1997). If small mammals are unfamiliar with habitat across the road, they should produce different paths than when moved within the same patch. Specifically, we predicted that the paths of animals moved across roads should be more convoluted (i.e., more u-turns), less oriented towards the destination, and should be longer than animals moved within a contiguous forest.

Question two: What type of barrier response do small mammals show towards roads?

We hypothesized that roads can act as barriers to small mammal movement in three ways. The first hypothesis is that animals avoid roadside habitat because of increased pollution and noise associated with traffic volume. Existing literature has shown that small mammals do not appear to avoid road verges, and may actually seek out 
roadside edge for habitat (Adams and Geis 1983). Thus, we expected that the number of small mammals trapped would be similar near the road and farther away from the road. However, if the first hypothesis were true, we would expect to trap more small mammals farther into the forest, and to find a negative effect of traffic volume on the number of animals trapped, since traffic emissions would be correlated with traffic volume on the roads.

Our second hypothesis was that the decreased movement of small mammals across roads is due to the avoidance of the road structure itself. If small mammals avoid the road surface but not the roadside habitat, we would expect the number of animals trapped in roadside habitat to be similar to the number trapped farther into the forest. We also expect that small mammals should cross roads less frequently than move within continuous forest.

Our third hypothesis is that small mammals do not avoid roads but experience high traffic mortality that decreases movement success. If small mammals experience high levels of mortality, then we would expect a significant effect of traffic volume on the movement of small mammals across roads. If high numbers of small mammals die on roads, we would expect to trap fewer animals in roadside habitat than farther away from roads.

Question three: Do white-footed mice and eastern chipmunks react differently to roads?

If we found support for the roadside habitat aversion hypothesis, we predicted that fewer chipmunks would be trapped at the roadside since white-footed mice are highly associated with edge habitat. We predicted that chipmunks would also be more sensitive to traffic volume since they are a diumal species that may have a higher probability of 
collisions with daily traffic volume. Finally, we predicted that we would recapture fewer chipmunks from translocations across roads than white-footed mice since chipmunks would avoid the surface of the roads due to their forest cover specificity.

\section{METHODS}

We employed three trapping protocols to test our predictions (Table 2). However, all protocols had the following features in common. We used Sherman ${ }^{\mathrm{TM}}$ non-folding aluminium traps baited with a peanut butter/sunflower seed mixture. The traps were capable of capturing animals that ranged from less than $15 \mathrm{~g}$ (e.g., Sorex spp., juvenile Peromyscus sp.) to over $500 \mathrm{~g}$ (e.g., Sciurus sp.). We trapped each site for 6 consecutive nights, and checked traps in early morning (8 - 10 A.M.) and late aftemoon (4 - 5 P.M.). Each captured animal was given an individual number using sequentially numbered Monel ${ }^{\mathrm{TM}}$ fingerling tags, and species, sex, age and the trap location were recorded. The mass of the animals was read from a hanging Pezola ${ }^{\mathrm{TM}}$ scale with accuracy to $1 \mathrm{~g}$. Adults were characterised by their golden brown (vs. light grey for juveniles) pelage, as well as secondary sexual characteristics.

\section{Site Selection}

All sites selected for trapping protocols one and two met the following criteria. Sites included a $100 \mathrm{~m}$ two lane paved section of road that did not have approaches, driveways, or culverts along its length (Figures 2 and 3). Streetlights and sidewalks were also not present. The road included shoulders and ditches. Road width (measured from forest edge to forest edge using a tape measure) ranged from $17 \mathrm{~m}$ to $28 \mathrm{~m}$ but averaged $20.9 \pm 3.0 \mathrm{~m}$ ( 1 standard deviation). The edge of the roadside trapping grids was $10 \mathrm{~m}$ 
from the road edge so traps were always in the forest, usually $2-3 \mathrm{~m}$ from the forest edge (Figures 2 and 3). The trapping sites were forested, dominated by maple (Acer spp.), pine (Pinus spp.) and spruce (Picea spp.). Although dominant vegetation varied among sites, habitat on both sides of the road was consistent within sites. We obtained traffic volume estimates (average annual daily traffic (AADT)) from the City of Ottawa (May - June counts), and selected road segments to cover a large range of values, from 50 to over 15000 AADT.

In 2003, we continued a study that was begun by Bender (2000) and followed his experimental protocol (trapping protocol three). He translocated white-footed mice and chipmunks from 20 forested sites to other forested sites across varying distances and number of roads (with varying traffic volumes). We selected an additional 4 sites to increase the number of roads that were in excess of 2000 AADT $(3078,8254,10300$, 13423 AADT) which resulted in 24 sites for the study (Figure 4).

\section{Trapping Protocols}

We employed three different trapping protocols: trapping protocols one and two were established at a combined 28 sites in the Ottawa-Carleton region of Ontario from May to mid-August during 2002 and 2003. Trapping protocol three was established in summer 1999 for 11 weeks during June through August, and continued for 4 weeks in 2003 during the summer months (Table 2).

Thirteen sites were established using trapping protocol one, which consisted of three trapping grids that contained 36 traps each (Table 2, Figure 2). The grids were set up perpendicular to the road and were centered within the $100 \mathrm{~m}$ road segment length. Within each grid, 6 transects separated by $10 \mathrm{~m}$ were parallel to the road. In each of these 
transects, we laid 6 traps separated by $10 \mathrm{~m}$, which resulted in a 6 by 6 grid. At each site, two grids (Roadside 1 and Roadside 2) were set up $10 \mathrm{~m}$ from the road edge, typically 2 $3 \mathrm{~m}$ into the forest, on either side of the road. The third grid (Interior) had its first transect $80 \mathrm{~m}$ from the road (i.e., $30 \mathrm{~m}$ away from the interior edge of Roadside 1). The distance between Roadside 1 and 2 was not constant but varied less than $5 \mathrm{~m}$ among sites.

We established 15 sites that employed trapping protocol two, which consisted of one trapping grid that contained 36 traps (Table 2, Figure 3) laid out as in protocol one. Captured white-footed mice and eastern chipmunks were translocated in mesh bags $35 \mathrm{~m}$ from the edges of the grid, perpendicular to the road. Accordingly, those animals that were translocated across the road were released approximately $10 \mathrm{~m}$ inside the forest, while those translocated within the same patch ended up $85 \mathrm{~m}$ from the forest edge. At the two release points, the releaser always stood between the released animals and the trapping grid from which they were removed. After releasing the animals, the releaser returned directly to the grid.

Sites for trapping protocol one and two were often trapped in separate forest patches concurrently, but no more than 2 sites (trapping protocol one or two) were trapped per week.

Trapping protocol three was a continuation of Bender's (2000) trapping protocol. At each home patch, 4 transects of 18 traps, separated by $10 \mathrm{~m}$ were established running perpendicular to the road. Although the distance between transects ranged between 10 and $50 \mathrm{~m}$ in the original protocol, we kept the distance between transects at $10 \mathrm{~m}$. Each transect began $10 \mathrm{~m}$ from the edge of the forest, and traps were separated by $5 \mathrm{~m}$ (Table 2). 
Are roads barriers to small mammal movement?

Spontaneous Movement

To test whether roads are barriers to small mammal home range movements, we investigated the effect of roads on spontaneous (i.e., not forced) animal movement, and the number of captured individuals in roadside habitat versus farther into the forest (Table 2, Figure 2). We selected 13 sites using trapping protocol one to measure the movement patterns of small mammals across roads and within continuous forest. In each trapping grid, we trapped and marked all individual white-footed mice and eastern chipmunks, and then released them within $1 \mathrm{~m}$ of the trap from which they were removed.

To determine whether small mammals include roads in their home range, we conducted a contingency $\chi^{2}$ test to compare whether fewer animals moved across roads between roadside grids than expected and whether more animals moved within continuous forest between the Roadside 1 and Interior grids than expected.

\section{Familiarity}

We also investigated whether small mammals were familiar with habitat across roads by comparing the paths of animals that were translocated across roads and within continuous forests using trapping protocol two (Table 2, Figure 3). We marked a subset of the translocated animals with fluorescent powder (Radiant Color Corp., Richmond, California), which sloughs off and leaves a trail depicting their movements following release. For this experiment, we used 13 ( 7 across the road, 6 within the patch) whitefooted mice and 15 ( 7 across the road, 8 within the patch) eastern chipmunks. At the release point, we transferred animals from the mesh bag into a plastic bag containing a 
small amount of fluorescent powder (Figure 5) and covered them as per Lemen and Freeman (1985). The powder sloughed off as the animal moved through the forest and fluoresced under ultraviolet (UV) radiation, which allowed us to follow the paths at night.

At night, we used a UV light and flagging tape to mark the trails left by the powdered small mammals. Flagging tape was placed on vegetation along each trail at approximately $1 \mathrm{~m}$ intervals and more frequently if the path was highly convoluted. We followed the paths until they entered the road or grid, or until the trail was so faint that 5 min of searching revealed no additional powder. On the following day, we used a compass and field measuring tape to measure the bearing and distance from the release point to the first flag, from the first flag to the next, and so on, until the last flag.

As mentioned, the releaser always stood between the released animal and the trapping grid from which the animals were moved. Since the first few meters of the path likely represented movement away from the releaser, we analyzed all paths starting $5 \mathrm{~m}$ away from the release point, and all paths $<10 \mathrm{~m}$ in length were removed from analysis.

The 25 remaining paths ( 4 mice, 8 chipmunks within patch, and 6 mice, 7 chipmunks across the road) were entered into a geographic information system (ArcView 3.2), to produce the paths created from the marked headings and distances between successive points for each individual. We used one-way t-tests to analyze the difference in linearity and length and orientation of paths created by small mammals in the two translocation directions (i.e., across the road vs. into the forest). See Appendix D for sample calculation of meaning bearings. Linearity compares the total distance travelled to the distance between the initial and final points in the path. The values range between 0 and 1 , where $r=1$ is a perfectly straight path. We expected animals to orient to their 
home range after translocation, and so expected animals to orient relative to the trapping grid. We arbitrarily chose 180 degrees for animals translocated across roads and 360 degrees for animals translocated within continuous forest because of the opposite nature of the translocation directions (Figure 6).

\section{What type of barrier effect do roads exert on small mammals?}

\section{Numbers Trapped}

We compared the number of animals trapped near the road vs. farther into the forest using a pairwise t-test by taking the mean of the total number of animals trapped in Roadside 1 and Roadside 2 and comparing that to the number trapped within the forest Interior grid for each site (Figure 2). To test the prediction that traffic decreases the number of animals that are trapped, we performed a simple linear regression comparing the number of animals found at each site to the traffic volume, for both species combined and for each species separately.

\section{Short Distance Translocations}

To determine whether small mammals were more or less likely to cross roads during forced movement, we translocated animals after capturing them using trapping protocols two and three (Figures 3 and 4). We employed trapping protocol two in 15 sites to determine whether small mammals crossed roads when moved within their theoretical home range limits $\left(475-700 \mathrm{~m}^{2}\right.$ for chipmunks (Getty 1981a), $100 \mathrm{~m}^{2}$ range for whitefooted mice (in (Nupp and Swihart 2000)). As noted above, after their initial capture, individually marked white-footed mice and eastern chipmunks were immediately translocated either across the road or within continuous forest. Any marked animals that were recaptured within the trapping session for each site ( 6 nights) were recorded as 
successfully returned. We compared the return rates of small mammals translocated across the road to those translocated within the patch using $\chi^{2}$ tests of independence.

\section{Long Distance Translocations}

Small mammals also travel longer distances for events such as dispersal. We continued a trapping protocol established by Bender (2000) to determine whether small mammals were less likely to move successfully through a landscape when road density and traffic volume increased. Animals were trapped in 24 sites using trapping protocol three (Figure 4). As per Bender (2000), each home patch was trapped for 6 consecutive nights; in 1999, two home patches were trapped per week, but only one home patch was trapped per week in 2003. On their initial capture, all white-footed mice and eastern chipmunks were marked with an ear tag and then translocated to one of three to five surrounding forest patches in the landscape over varying distances and number of intervening roads. Any tagged mice or chipmunks that returned within the 6 night trapping session were recorded as successfully returning from translocation. Although Bender (2000) used a GIS based application to measure edge-to-edge distance between destination and home patches, we used field marking tape since all animals in our 4 sites were translocated across one road into an adjacent forest. We used a stepwise multiple logistic regression with number of roads and interpatch distance as independent variables.

\section{Traffic Volume}

If small mammals readily attempt to cross roads but experience a high rate of mortality, traffic volume should be an important variable in the decreased small mammal movement success. We therefore added a traffic volume variable to our spontaneous movement and translocation studies. We performed a multiple logistic regression for 
animals that either spontaneously crossed roads or returned from short distance translocations across roads to determine whether traffic volume affects movement success. We also added a traffic volume variable to the multiple logistic regression for long distance translocations. In this case, traffic volume was the sum of volumes for all of the roads between the home and destination patches.

Species

Life history and behavioural characteristics may also affect the degree to which roads are barriers to movement. We therefore added a species (white-footed mouse or eastern chipmunk) variable to our spontaneous movement and translocation (both short and long distance) multiple logistic regressions. Because we predicted chipmunks would be more strongly affected by traffic volume, we also added the interaction term between species and traffic to the multiple logistic regressions.

All statistical analyses were completed in SAS version 6(1990) or by hand.

\section{RESULTS}

\section{Are roads barriers to small mammal movement?}

Spontaneous movement

We captured 136 white-footed mice and 104 eastern chipmunks in 8424 trap nights. Sixty-eight mice and 54 chipmunks were recaptured at least once after their initial capture $(50 \%$ and $52 \%$ recapture rate, respectively). Forty-one small mammals spontaneously moved between grids, 36 (17 mice, 19 chipmunks) of 177 captured animals moved between Roadside 1 and Interior grids and 5 ( 4 chipmunks and 1 mouse) of 188 moved across roads between Roadside 1 and 2 (Figure 7). This difference was 
statistically significant $\left(\mathrm{df}=1, \chi^{2}=24.4, \mathrm{p}<0.0001\right)$. Due to the small number of animals spontaneously crossing roads, the multiple logistic regression of the effects of species, traffic volume and the interaction between species and traffic volume on the movement of small mammals across roads could not be performed.

Familiarity

Animals translocated across roads had significantly straighter paths than did those translocated within continuous forests (Figures 8 and $9, \mathrm{t}=2.8, \mathrm{df}=23, \mathrm{p}=0.005$ ). This was also true for chipmunks, and tended to be true for mice, when analysed separately (t $=2.31, \mathrm{df}=13, \mathrm{p}=0.02 ; \mathrm{t}=1.28, \mathrm{df}=8, \mathrm{p}=0.11$, respectively). There was no difference in the length of the paths of animals translocated across roads and continuous forests (Figure $10, t=1.04, d f=23, p=0.15)$, regardless of species (chipmunks: $t=0.82, d f=$ 13, $\mathrm{p}=0.21$, mice: $\mathrm{t}=0.15, \mathrm{df}=8, \mathrm{p}=0.44$ ). There was also no significant difference in the orientation of the paths of animals translocated across the road or within continuous patches (Figure 11, $\mathrm{df}=23, \mathrm{t}=1.10, \mathrm{p}=0.28)$

\section{What type of barrier effect do roads exert on small mammals?}

Number Trapped

There was no significant effect of grid location on the number of animals captured (Figure 12; paired- $\mathrm{t}=1.79, \mathrm{df}=12, \mathrm{p}=0.099$ ), although roadside grids tended to have higher capture rates (mean $6.6 \pm 0.14$ individuals) than interior grids (mean $5.3 \pm 0.13$ individuals). This was due to significantly higher numbers of chipmunks caught in roadside grids than forest interior (paired-t $=2.5, \mathrm{df}=12, \mathrm{p}=0.028$ ) since mice showed no difference (paired $-t=0.16, d f=12, p=0.88$ ). There was no effect of traffic on the 
number of animals trapped in the sites (Figure 13, Table 3), even when white-footed mice (Table 4) and chipmunks (Table 5) were analysed separately.

\section{Shor Distance Translocations}

Of the 92 small mammals translocated during trapping protocol two, 58 were recaptured. Of the 45 small mammals ( 21 white-footed mice, 24 eastern chipmunks) translocated across roads, 24 returned (14 mice, 10 chipmunks). Of the 47 small mammals (28 mice, 19 chipmunks) that were translocated with the same patch, 35 returned (19 mice, 16 chipmunks). The difference in the number of animals returning from translocation when translocated across roads vs. within forest was significant (Figure 14; $\mathrm{df}=1, \chi^{2}=7.28, \mathrm{p}=0.0070$ ). The results from the multiple logistic regression showed no significant effect of traffic volume, species, nor the interaction between species and traffic volume (Table 6) on small mammal return rates from short distance translocations across roads.

\section{Long Distance Translocations}

Altogether, we marked and translocated 310 (281 by Bender in 1999, 29 during 2003 ) individuals (197 white-footed mice and 115 eastern chipmunks) from 24 home patches over 10, 368 trap nights using protocol three. After controlling for a strong effect of distance between home and destination patches, we found that the number of intervening roads also significantly negatively affected small mammal return rates (Figure 15, Table 7, $\mathrm{df}=1$, Wald $\chi^{2}=16.4, \mathrm{p}<0.0001$ ). Small mammal return rate decreased by about $50 \%$ for every road that occurred between the home and destination patch. Traffic volume tended to decrease small mammal return rates (Figure 16, Table 7, $\left.\mathrm{df}=1, \chi^{2}=2.98, \mathrm{p}=0.084\right)$, but species $\left(\mathrm{df}=1\right.$, Wald $\left.\chi^{2}=0.34, \mathrm{p}=0.55\right)$ and the 
interaction between traffic and species ( $\mathrm{df}=1$, Wald $\left.\chi^{2}=0.0, \mathrm{p}=0.88\right)$ did not significantly affect small mammal return rates from these translocations.

Over the course of the two field seasons, we spent approximately 600 hours on the roads at our sites. Although we did not systematically search for carcasses (as per Lode 2000), we did not observe any dead animals along the sites during the study.

\section{DISCUSSION}

Roads are barriers to small mammal home range movements. White-footed mice and eastern chipmunks were less likely to cross roads than expected if they were not affected by roads; this pattern of movement is like that reported for bank voles (Bakowski and Kozakiewicz 1988), desert rodent populations (Garland and Bradley 1984), tropical forest species (Goosem 2002), and grassland rodent species (Clark et al. 2001).

We hypothesised that if roads decrease small mammal movement, white-footed mice and eastem chipmunks should not be familiar with habitat across roads. We predicted that animals translocated across roads would have longer, less straight, less oriented paths than those translocated on the same side the road. However, only the test of linearity had a significant result, and it was opposite to our predictions. Both mice and chipmunks that were translocated across roads had straighter paths than those translocated within the forest. We expected to see increased u-turns because that is typically how small mammals orient themselves in unfamiliar areas (Thibault and Bovet 1999). We hypothesize that the mice and chipmunks were not familiar with the habitat across roads, but were using the roads as a cue. Since we translocated animals across roads in a mesh bag during daylight hours, it is possible that the mice and chipmunks 
were aware of the translocation across the road and knew where to return. Although the animals that were translocated across roads were not significantly oriented towards the trapping grid, most were oriented towards the general area of the road, suggesting that the animals may have used the road as a cue to their movement. The lack of statistical significance for orientation or path length may have been affected by the small sample size in this portion of the study.

We did not find support for the hypothesis that animals avoid roadside habitats due to increased levels of pollution or noise associated with traffic emissions. We found that neither chipmunks nor mice avoided roadside habitat, and that chipmunks were trapped more often in habitat near roads. These results are similar to those found by Garland and Bradley (1984) who showed that there was no relationship between proximity to the road and home range size or life span of the desert rodents studied. Small mammals tended to be trapped more often in grids near roads than farther into the forest, likely because of the increased vegetative complexity that occurs there (Anderson et al. 2003b). Both white-footed mice and eastern chipmunks are associated with high vegetation complexity (Anderson et al. 2003b) and increased course woody debris (Zollner and Crane 2003b), which are in turn associated with forest edges. The number of animals trapped also did not depend on the traffic volume on the road. This result also suggests that small mammal movement is not affected by the pollution or noise associated with vehicular traffic.

We also did not find support for the hypothesis that decreased small mammal movement across roads is due to increased mortality associated with traffic volume. We predicted a negative relationship between traffic volume and small mammal movement if 
mortality was responsible for the barrier effect. However, we found no effect of traffic volume on small mammals during short distance movements and only a marginal effect during long distance movements. These results support existing literature that traffic does not affect small mammal movement at the short distance level (Oxley et al. 1974; Goosem 2002). However, our results are the first to test for and find an effect of traffic on long distance small mammal movement. Although the existence of roads is a much stronger predictor of small mammal movement, over longer distances, small mammals may experience higher levels of mortality. These results suggest that for highly vagile animals that travel large distances for dispersal (i.e. white-footed mice have been shown to travel on the order of 1000 's of m (Bowman et al. 2001; Maier 2002)), traffic volume may decrease movement success since it increases the probability of mortality.

Based on our results, we conclude that decreased movement across roads is due to road aversion. We found support for our three predictions: (1) small mammals were trapped at the same rate or more often in habitat near roads than farther away from roads, (2) there was a negligible effect of traffic and no evidence of increased mortality and (3) small mammals were less likely to move across roads than within continuous forest. These results support findings by Bakowski and Kozakiewicz (1988), who found that bank voles translocated into continuous forest return to the trapping grid faster and in greater numbers than those translocated to the other side of the road. Over longer distances, the probability of an animals returning from translocations decreased by approximately $50 \%$ for every road that is inserted between the home and destination, suggesting that roads significantly negatively influence small mammal movement success through a landscape. 
How strong the road effects are as barriers may depend on the incentive the animals have to move. Over $50 \%$ of animals that were translocated across roads were recaptured, as compared to $3 \%$ of animals spontaneously crossing the road. These results suggest that during regular home range movements, roads are avoided, but during times where movement across roads is necessary, small mammals are capable of crossing. Clark et al. (2001) showed the same trend in prairie rodent species that they trapped and translocated across roads: there is a slightly higher probability that displaced animals will cross roads than those animals that are not displaced. These results suggest that small mammals are capable of moving across roads but their behaviour towards roads prevents them from doing so. Patches that are separated by roads may not isolated from each other since some individuals are capable of crossing roads, but dispersal behaviour has yet to be studied with regards to roads.

What is it about the road itself that reduces the likelihood of small mammals moving across it? Oxley et al. (1974) showed that road clearance or width, as compared to traffic load or substrate type, was the best predictor of small mammal movement, but this could be attributed to decreased canopy closure, ground cover and/or vegetation complexity. Eastern chipmunks have been shown to move through forest gaps upwards of $250 \mathrm{~m}$ successfully (Bowman and Fahrig 2002), which suggests decreased canopy cover may not significantly decrease their movement across roads. We showed that whitefooted mice and eastern chipmunks were trapped in high numbers along roadside habitat where vegetation complexity is its highest in the forest (Anderson 2003a). Because small mammals do not often move through habitats with little or no ground cover or vegetative 
complexity (McMillan and Kaufman 1995; Seamon and Adler 1996b; Zollner and Crane $2003 a$ ), we hypothesize this is the reason small mammal movement is decreased at roads. We predicted that mice would be more mobile across roads than chipmunks for all of the hypothetical barrier effects, but we did not find a significant effect of species in any of the analyses. Several explanations for the lack of difference between chipmunks and mice are possible. Although white-footed mice are considered to be habitat generalists, they prefer to move and live in woodland habitat and rarely leave forest cover (Drickamer 1990; Seamon and Adler 1996a). Alternatively, although white-footed mice are capable of living in several different habitats, this may not increase the likelihood that they will successfully move across roads. Although chipmunks and mice have different activity times (diurnal vs. nocturnal, respectively), traffic has little to no effect on small mammal movement, which suggests activity times would have little effect on how small mammals react to roads.

\section{Future Studies:}

Recent studies show that mitigation structures such as culverts aid in movement of animals, including ungulates (Clevenger et al. 2001a), reptiles (Lode 2000), and small mammals (Yanes et al. 1995; Rodriguez et al. 1996; Lode 2000) from one side of the road to the other. However, most of these studies did not compare the movement of small mammals without culverts to movement when culverts are available (Clevenger et al. 2001b), but see Lode 2000). A continuation of our study would be to select sites that include culverts along their length and compare them to sites without culverts. Results from such a study would indicate whether the addition of such underpasses for small mammals could ameliorate the negative effects of roads on their movement. 
Another study stemming from our research would be to investigate whether small mammal relative densities are related to road density. Our results show that movement decreases as road density increases. Because small mammal populations need movement to recolonize extinct patches, increased road density should negatively affect small mammal populations.

\section{Conclusion:}

Small mammal population dynamics are characterized by extinctions and recolonizations of habitat patches in fragmented landscapes and as such, movement is important for small mammal population persistence. Not only are small mammals reluctant to cross roads during daily movements, but at a larger scale, movement success decreases by about $50 \%$ for every road that lies between the home and destination sites. Our results suggest that this is due to avoidance of the road surface itself, rather than aversion to traffic emissions or to traffic mortality. Small mammals experience lower movement success at roads not because they are incapable of crossing, but because their behaviour prevents them from attempting.

\section{REFERENCES}

Adams,L.W. and Geis,A.D. 1983. Effects of roads on small mammals. Journal of Applied Ecology 20: 403-415.

Anderson,C.S., Cady,A.B., and Meikle,D.B. 2003a. Effects of vegetation structure and edge habitat on the density and distribution of white-footed mice (Peromyscus leucopus) in small and large forest patches. Canadian Journal of Zoology-Revue Canadienne de Zoologie 81: 897-904.

Anderson,C.S., Cady,A.B., and Meikle,D.B. 2003b. Effects of vegetation structure and edge habitat on the density and distribution of white-footed mice (Peromyscus 
leucopus) in small and large forest patches. Canadian Journal of Zoology-Revue Canadienne de Zoologie 81: 897-904.

Ashley,E.P. and Robinson,J.T. 1996. Road mortality of amphibians, reptiles and other wildife on the long point causeway, Lake Erie, Ontario. Canadian FieldNaturalist 110: 403-412.

Bakowski,C. and Kozakiewicz,M. 1988. The effect of forest road on bank vole and yellow-necked mouse populations. Acta Theriologica 33: 345-353.

Bender,D.J. 2000. Wildlife movement in fragmented habitats: the influence of landscape complexity. Ph.d.

Bovet,J. 1968. Trails of deer mice (Peromyscus maniculatus) traveling on the snow while homing. Journal of Mammalogy 49: 713-725.

Bowers,M.A. 1995. Use of space and habitats by the eastern chipmunk, Tamias-striatus. Journal of Mammalogy 76: 12-21.

Bowman,J. and Fahrig,L. 2002. Gap crossing by chipmunks: an experimental test of landscape connectivity. Canadian Journal of Zoology-Revue Canadienne de Zoologie 80: 1556-1561.

Bowman,J., Forbes,G.J., and Dilworth,T.G. 2001. Distances moved by small woodland rodents within large trapping grids. Canadian Field-Naturalist 115: 64-67.

Clark,B.K., Clark,B.S., Johnson,L.A., and Haynie,M.T. 2001. Influence of roads on movements of small mammals. Southwestern Naturalist 46:338-344.

Clarke,G.P., White,P.C.L., and Harris,S. 1998. Effects of roads on badger Meles meles populations in south-west England. Biological Conservation 86: 117-124.

Clarke,M.F., Dasilva,K.B., Lair,H., Pocklington,R., Kramer,D.L., and McLaughlin,R.L. 1993. Site familiarity affects escape behavior of the eastem chipmunk, Tamiasstriatus. Oikos 66: 533-537. 
Clevenger,A.P., Chruszez,B., and Gunson,K. 2001a. Drainage culverts as habitat linkages and factors affecting passage by mammals. Joumal of Applied Ecology 38: 13401349.

Clevenger,A.P., Chruszez,B., and Gunson,K.E. 2001b. Highway mitigation fencing reduces wildlife-vehicle collisions. Wildlife Society Bulletin 29: 646-653.

deMaynadier,P.G. and Hunter,M.L. 2000. Road effects on amphibian movements in a forested landscape. Natural Areas Journal 20: 56-65.

Develey,P.F. and Stouffer,P.C. 2001. Effects of roads on movements by understory birds in mixed-species flocks in central Amazonian Brazil. Conservation Biology 15: $1416-1422$.

Drickamer,L.C. 1990. Microhabitat preferences of 2 species of deermice Peromyscus in a northeastern United-States deciduous hardwood forest. Acta Theriologica 35: 241-252.

Dunford,C. 1970. Behavioral aspects of spatial organization in chipmunk, Tamiasstriatus. Behaviour 36: 215-\&.

Fahrig,L. and Merriam,G. 1985. Habitat patch connectivity and population survival. Ecology 66: 1762-1768.

Garland,T. and Bradley,W.G. 1984. Effects of a highway on Mojave desert rodent populations. American Midland Naturalist 111: 47-56.

Getty, T. 1981a. Structure and dynamics of chipmunk home range. Joumal of Mammalogy 62: 726-737.

Getty,T. 1981b. Territorial behavior of eastern chipmunks (Tamias striatus) - encounter avoidance and spatial time-sharing. Ecology 62:915-921.

Goosem,M. 2001. Effects of tropical rainforest roads on small mammals: inhibition of crossing movements. Wildlife Research 28: 351-364. 
Goosem,M. 2002. Effects of tropical rainforest roads on small mammals: fragmentation, edge effects and traffic disturbance. Wildlife Research 29:277-289.

Halama,K.J. and Dueser,R.D. 1994. Of mice and habitats-tests for density-dependent habitat selection. Oikos 69: 107-114.

Hels, T. and Buchwald,E. 2001. The effect of road kills on amphibian populations. Biological Conservation 99: 331-340.

Henein,K., Wegner,J., and Merriam,G. 1998. Population effects of landscape model manipulation on two behaviourally different woodland small mammals. Oikos 81: 168-186.

Ims,R.A. 1995. Movement patterns related to spatial structures. In Mosaic landscapes and ecological processes. Edited by L.Hansson, L.Fahrig, and G.Merriam. Chapman and Hall, London. pp. 85-109.

Jamon,M. and Benhamou,S. 1989. Orientation and movement patterns of wood mice (Apodemus sylvanicus) released inside and outside a familiar area. Journal of Comparative Psychology 103: 54-61.

Keller,I. and Largiader,C.R. 2003. Recent habitat fragmentation caused by major roads leads to reduction of gene flow and loss of genetic variability in ground beetles 69. Proceedings of the Royal Society of London Series B-Biological Sciences 270: 417-423.

Kozakiewicz,M. 1993. Habitat isolation and ecological barriers - the effect on small mammal populations and communities. Acta Theriologica 38: 1-30.

Krohne,D.T. 1997. Dynamics of metapopulations of small mammals. Journal of Mammalogy 78: 1014-1026.

Krohne,D.T. and Hoch,G.A. 1999. Demography of Peromyscus leucopus populations on habitat patches: the role of dispersal. Canadian Journal of Zoology-Revue Canadienne de Zoologie 77: 1247-1253.

Lemen,C.A. and Freeman,P.W. 1985. Tracking mammals with fluorescent pigments - a new technique. Journal of Mammalogy 66: 134-136. 
Lode,T. 2000. Effect of a motorway on mortality and isolation of wildlife populations. Ambio 29: 163-166.

Mader,H.J. 1984. Animal habitat isolation by roads and agricultural fields. Biological Conservation 29: 81-96.

Mader,H.J., Schelle,C., and Kornacker,P. 1990. Linear barriers to arthropd movements in the landscape. Biological Conservation 54: 209-222.

Maier,T.J. 2002. Long-distance movements by female White-footed Mice, Peromyscus leucopus, in extensive mixed-wood forest. Canadian Field-Naturalist 116: 108111.

McMillan,B.R. and Kaufman,D.W. 1995. Travel path characteristics for free-living white-footed mice (Peromyscus-leucopus). Canadian Journal of Zoology-Revue Canadienne de Zoologie 73: 1474-1478.

Merriam,G. and Wegner,J. 1992. Local extinctions, habitat fragmentation, and ecotones. In Landscape Boundaries: Consequences for biotic diversity and ecological flows. Edited by A.J.Hansen and di Castri F. Springer-Verlag, New York. pp. 150-159.

Middleton, J. and Merriam,G. 1981. Woodland mice in a farmland mosaic. Journal of Applied Ecology 18: 703-710.

Munguira,M.L. and Thomas,J.A. 1992. Use of road verges by butterfly and burnet populations, and the effect of roads on adult dispersal and mortality. Journal of Applied Ecology 29:316-329.

Nadeau,J.H., Lombardi,R.T., and Tamarin,R.H. 1981. Population-structure and dispersal of Peromyscus leucopus on Muskeget Island. Canadian Journal of Zoology-Revue Canadienne de Zoologie 59: 793-799.

Nellemann,C., Vistnes,I., Jordhoy,P., and Strand,O. 2001. Winter distribution of wild reindeer in relation to power lines, roads and resorts. Biological Conservation 101: $351-360$. 
Nupp,T.E. and Swihart,R.K. 2000. Landscape-level correlates of small-mammal assemblages in forest fragments of farmland. Journal of Mammalogy 81: 512526.

Oxley,D.J., Fenton,M.B., and Carmody,G.R. 1974. Effects of roads on populations of small mammals. Joumal of Applied Ecology 11: 51 -59.

Reijnen,R. and Foppen,R. 1994. The effects of car traffic on breeding bird populations in woodland.1. Evidence of reduce habitat quality for willow warblers (Phylloscopus Trochilus) breeding close to a highway. Journal of Applied Ecology 31: 85-94.

Robitaille,J.F. and Aubry,K. 2000. Occurrence and activity of American martens Martes americana in relation to roads and other routes. Acta Theriologica 45: 137-143.

Rodriguez,A., Crema,G., and Delibes,M. 1996. Use of non-wildlife passages across a high speed railway by terrestrial vertebrates. Journal of Applied Ecology 33: 1527-1540.

Rondinini,C. and Doncaster,C.P. 2002. Roads as barriers to movement for hedgehogs. Functional Ecology 16:504-509.

Seamon,J.O. and Adler,G.H. 1996b. Population performance of generalist and specialist rodents along habitat gradients. Canadian Journal of Zoology-Revue Canadienne de Zoologie 74: 1130-1139.

Seamon,J.O. and Adler,G.H. 1996a. Population performance of generalist and specialist rodents along habitat gradients. Canadian Journal of Zoology-Revue Canadienne de Zoologie 74: 1130-1139.

Thibault,A. and Bovet,J. 1999. Homing strategy of the eastern chipmunk, Tamias striatus (Mammalia : Rodentia): Validation of the critical distance model. Ethology 105: 73-82.

Thiel,R.P. 1985. Relationship between road densities and wolf habitat suitability in Wisconsin. American Midland Naturalist 113: 404-407.

Vestal,B.M. and Hellack,J.J. 1977. Effects of available space on social interactions in male white-footed mice (Peromyscus leucopus). Behavioral Biology 19: 289-299. 
Yanes,M., Velasco,J.M., and Suarez,F. 1995. Permeabililty of roads and railways to vertebrates - the importance of culverts. Biological Conservation 71: 217-222.

Zollner,P.A. and Crane,K.J. 2003a. Influence of canopy closure and shrub coverage on travel along coarse woody debris by eastern chipmunks (Tamias striatus). American Midland Naturalist 150: 151-157.

Zollner,P.A. and Crane,K.J. 2003b. Influence of canopy closure and shrub coverage on travel along coarse woody debris by eastern chipmunks (Tamias striatus). American Midland Naturalist 150: 151-157.

Zollner,P.A. and Lima,S.L. 1997. Landscape-level perceptual abilities in white-footed mice: perceptual range and the detection of forested habitat. Oikos 80: 51-60. 
Table 1. Questions, hypotheses, predictions and tests used to examine the effect of roads on small mammal movement.

\begin{tabular}{|c|c|c|c|c|c|c|c|c|c|c|c|c|}
\hline 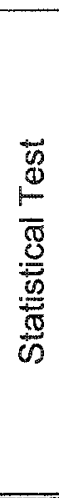 & 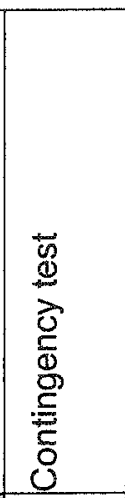 & $\begin{array}{l}\frac{9}{20} \\
\underline{\Phi} \\
F\end{array}$ & 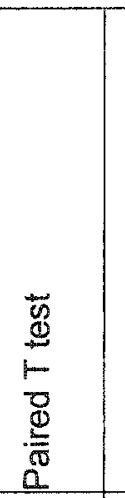 & 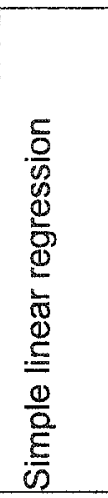 & 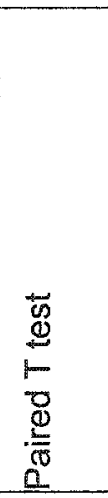 & 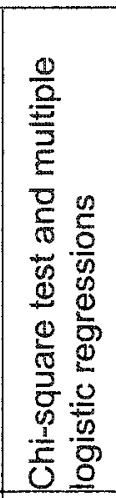 & 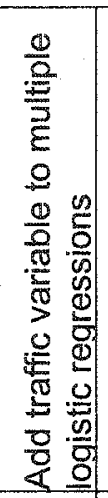 & 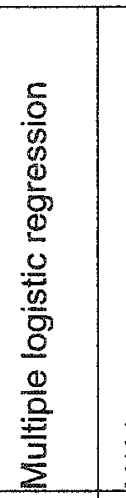 & $\stackrel{*}{\Sigma}$ & 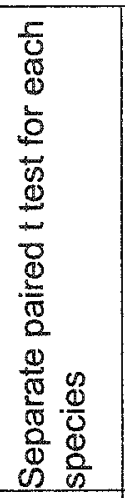 & 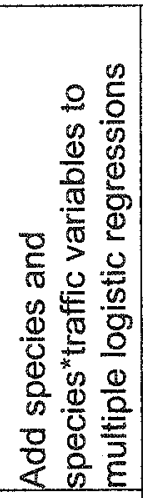 & 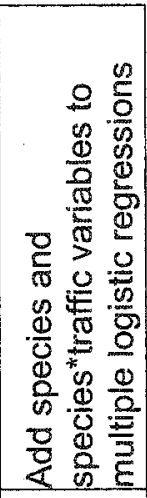 \\
\hline 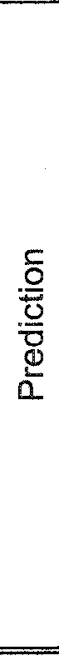 & 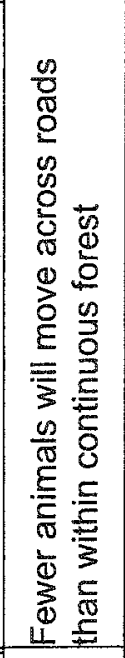 & 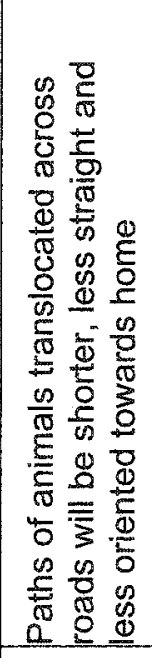 & 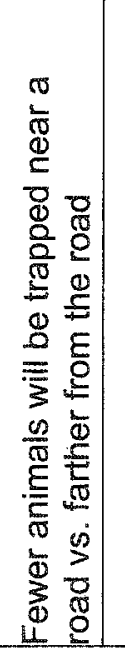 & 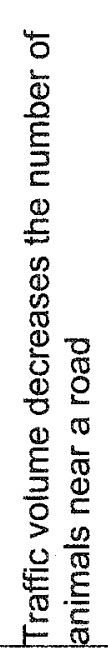 & 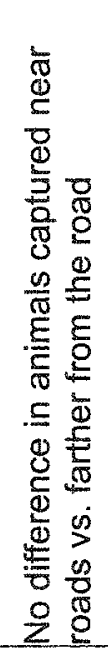 & 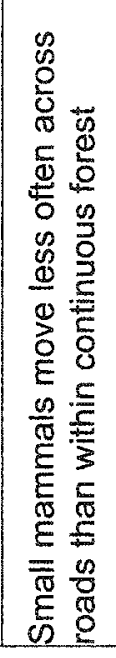 & 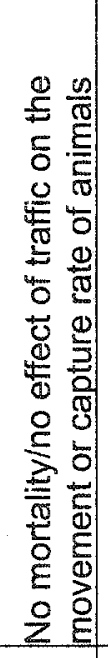 & 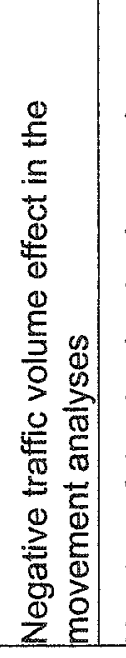 & 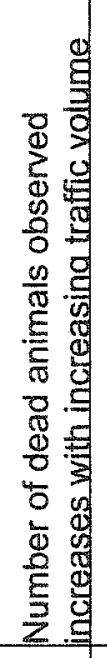 & 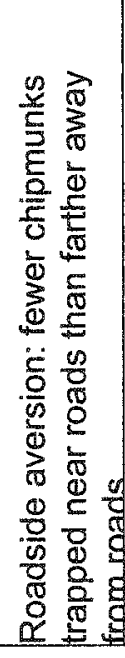 & 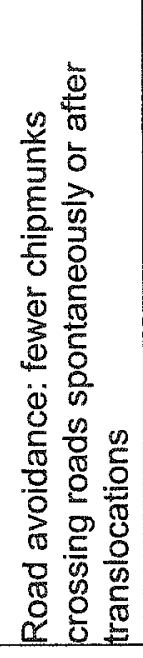 & 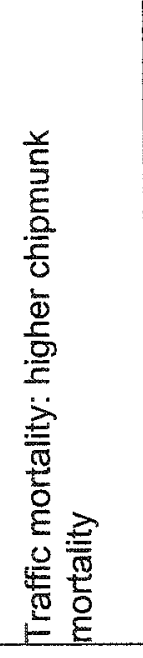 \\
\hline & 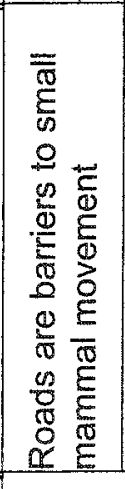 & 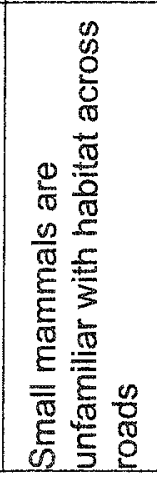 & 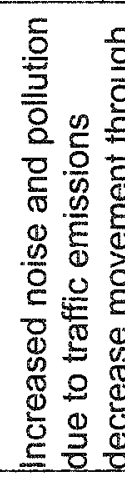 & 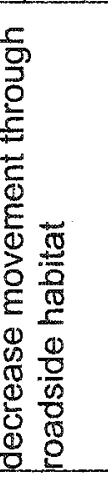 & 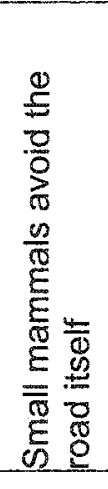 & & & 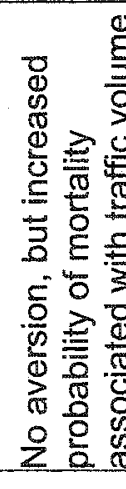 & & 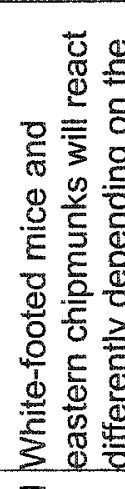 & 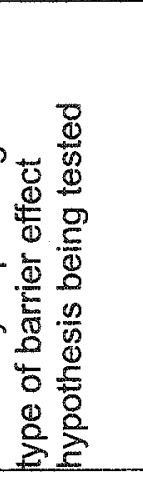 & \\
\hline & 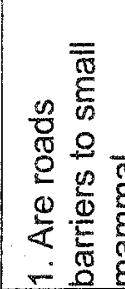 & & 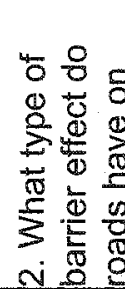 & 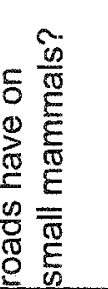 & & & & & & 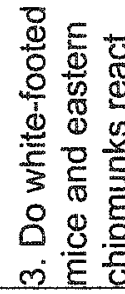 & $\stackrel{0}{0}$ & \\
\hline
\end{tabular}


Table 2. Summary of trapping protocols. In both experiments, the grids were trapped for 6 consecutive nights (7 days). Twenty of the 24 sites that used trapping protocol three were trapped by Bender in summer 2000 .

\begin{tabular}{|c|c|c|c|c|c|c|}
\hline 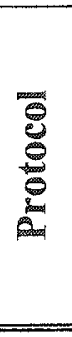 & 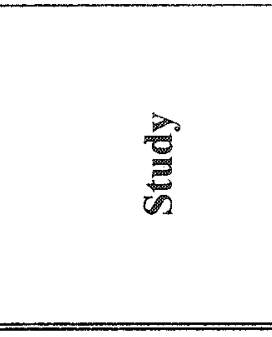 & 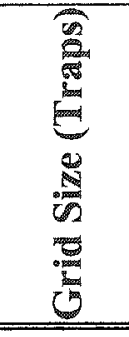 & 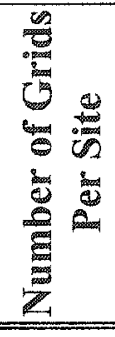 & 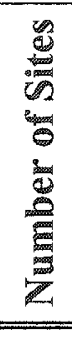 & 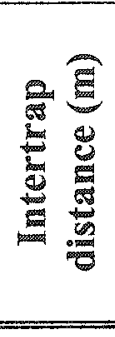 & 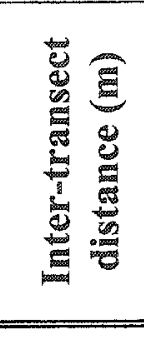 \\
\hline $\mathbb{1}$ & $\begin{array}{l}\text { Spontaneous } \\
\text { Movements } \\
\text { Number } \\
\text { Trapped }\end{array}$ & $6 \times 6$ & 3 & 13 & 10 & 10 \\
\hline 2 & $\begin{array}{l}\text { Short Distance } \\
\text { Translocations } \\
\text { Familiarity }\end{array}$ & $6 \times 6$ & 1 & 15 & 10 & 10 \\
\hline 3 & $\begin{array}{l}\text { Long Distance } \\
\text { Translocations }\end{array}$ & $4 \times 18$ & 1 & 24 & 5 & 10 to 50 \\
\hline
\end{tabular}


Table 3. ANOVA table for the simple linear regression of the effect of traffic volume on uumber of animals trapped $\left(\mathbb{R}^{2}=0.095\right)$. Number trapped is the sum of the individuals trapped at all three trapping grids at each site using protocol 1 (Table 2, Figure 2).

\begin{tabular}{lrrrrr}
\hline & of & \multicolumn{1}{c}{ SS } & MS & $F$ & Significance $F$ \\
\hline Regression & 1 & 113.5922 & 113.5922 & 1.159493 & 0.30462 \\
Residual & 11 & 1077.639 & 97.96714 & & \\
Total & 12 & 1191.231 & & & \\
\hline
\end{tabular}

Table 4. ANOVA table for the simple linear regression of effect of traffic volume on the number of mice trapped for each site $\left(\mathbb{R}^{2}=0.0031\right)$. Number trapped is the sum of the individuals trapped at all three trapping grids at each site using protocol 1 (Table 2, Figure 2).

\begin{tabular}{lrrrrr}
\hline & df & \multicolumn{1}{c}{ SS } & MS & $F$ & Significance $F$ \\
\hline Regression & 1 & 1.404132 & 1.404132 & 0.034336 & 0.856365 \\
Residual & 11 & 449.8266 & 40.89333 & & \\
Total & 12 & 451.2308 & & & \\
\hline
\end{tabular}

Table 5. ANOVA table for the simple linear regression performed of effect of traffic on the number of chipmunks trapped for each site $\left(\mathbb{R}^{2}=0.17\right)$. Number trapped is the sum of the individuals trapped at all three trapping grids at each site using protocol 1 (Table 2, Figure 2).

\begin{tabular}{lrrccr}
\hline & df & \multicolumn{1}{c}{ SS } & MS & $F$ & Significance $F$ \\
\hline Regression & 1 & 89.73779 & 89.73779 & 2.315747 & 0.156284 \\
Residual & 11 & 426.2622 & 38.75111 & & \\
Total & 12 & 516 & & & \\
\hline
\end{tabular}

Table 6. ANOVA table for the multiple logistic regression of effect of traffic volume, species and the interaction between traffic and species on the movement success of small mammal translocated short distances using trapping protocol two (Table 2, Figure 3).

\begin{tabular}{lrrrrr}
\hline \multicolumn{7}{c}{ Type III Sums of Squares } \\
\hline \multicolumn{1}{c}{ Parameter } & DF & Estimate & Standard & \multicolumn{1}{c}{ Wald Chi- } \\
Error & \multicolumn{1}{c}{ Square } & Pr > ChiSq \\
\hline Intercept & 1 & 0.74 & 0.65 & 1.32 & 0.25 \\
Species $\quad$ PL & 1 & 0.83 & 0.65 & 1.65 & 0.19 \\
Traffic Volume & 1 & -0.00007 & 0.000059 & 1.35 & 0.24 \\
Traffic*Species PL & 1 & -0.00005 & 0.000059 & 0.62 & 0.43 \\
\hline
\end{tabular}

Table 7. ANOVA table for the stepwise multiple regression of effect traffic, interpatch distance and the number of roads between patches on small mammal return rates from long distance translocations using trapping protocol three (Table 2, Figure 3). Interpatch distance refers to the edge-edge distance between home and destination patches, traffic volume is the sum of the average anmual daily traffic levels on each of the intervening roads between home and destination patches.

\begin{tabular}{lrrrrrr}
\hline \multicolumn{7}{c}{ Type III Analysis of Effects } \\
\hline Parameter & DF & Estimate & $\begin{array}{c}\text { Standard } \\
\text { Error }\end{array}$ & $\begin{array}{c}\text { Wald } \\
\text { Chi-Square }\end{array}$ & Pr > ChiSq \\
\hline Intercept & 1 & 0.74 & 0.32 & 5.22 & 0.0224 \\
Interpatch Distance & 1 & -0.0035 & 0.00069 & 25.7 & $<.0001$ \\
Traffic Volume & 1 & -0.00009 & 0.000053 & 2.98 & 0.084 \\
Number of Roads & 1 & -1.00 & 0.25 & 16.4 & $<.0001$ \\
\hline
\end{tabular}




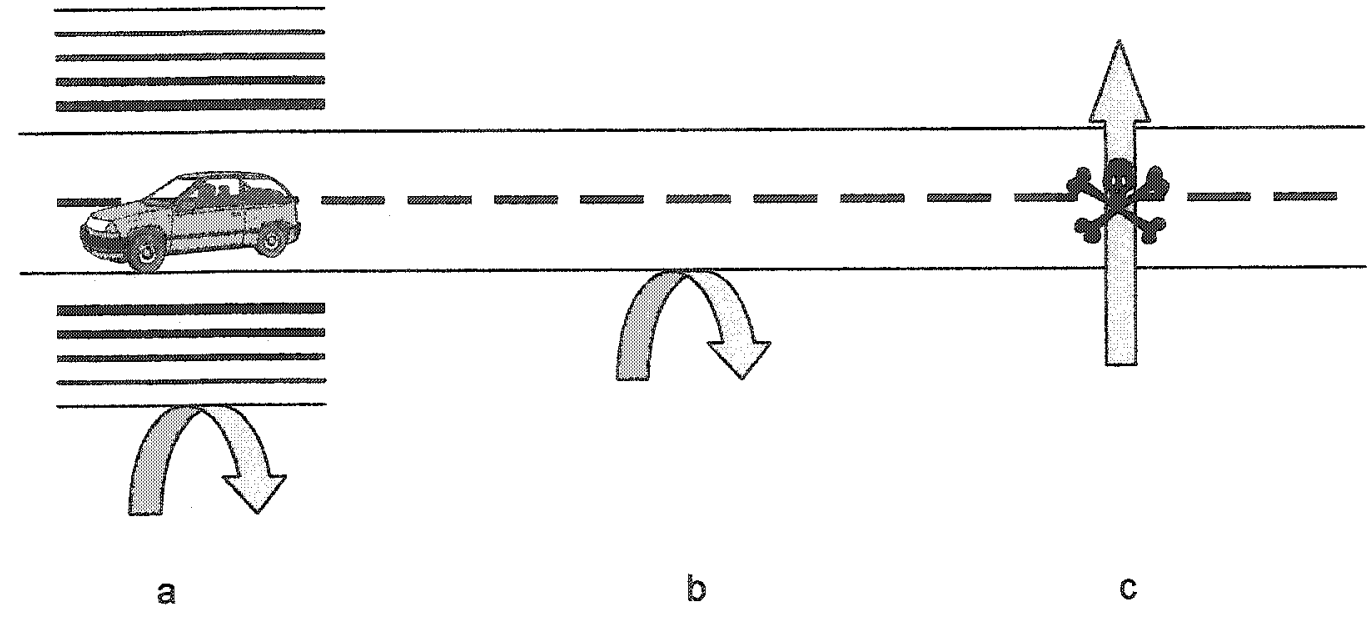

Figure 1. Three possible road barrier effects. a) Avoidance of roadside habitat due to increased pollution and noise levels associated with traffic volume. b) Avoidance of the road surface c) Animals attempt to cross roads but experience higher levels of mortality associated with traffic volume.

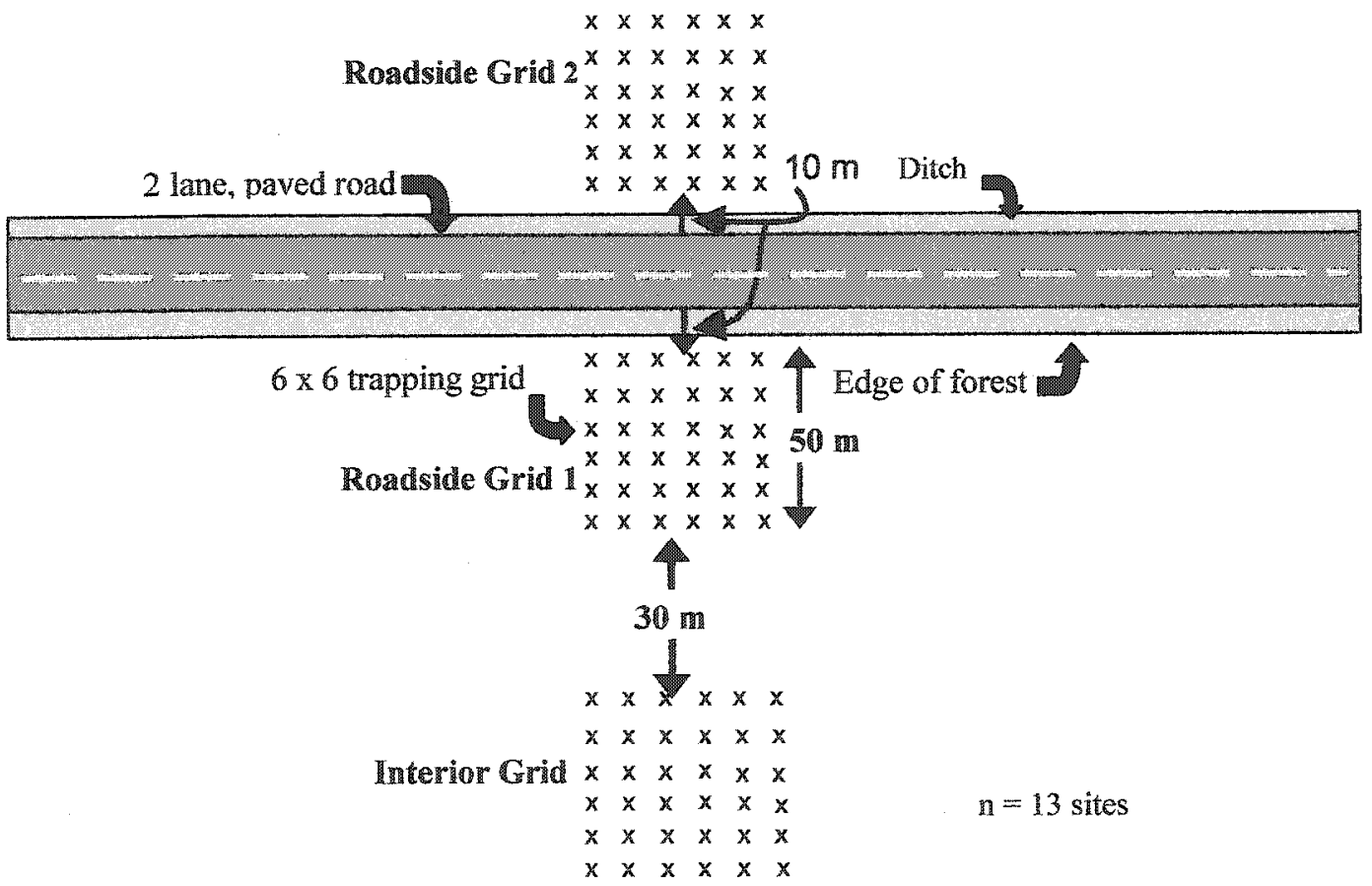

Figure 2. Depiction of trapping protocol one. The distance between Roadside grids 1 and 2 is approximately the same distance as between Roadside 1 and Interior grids. Each grid was composed of 6 transects with 6 traps in each, resulting in a 6 by 6 trapping grid. Intertrap and intertransect distance was $10 \mathrm{~m}$. Every site $(\mathrm{n}=13)$ included a $100 \mathrm{~m}$ segment of a two lane paved road with no culverts, lights, driveways or access roads along its length. Sites were chosen to cover a wide range of traffic volumes, from 50 average annual daily traffic (AADT) to 15433 AADT. 


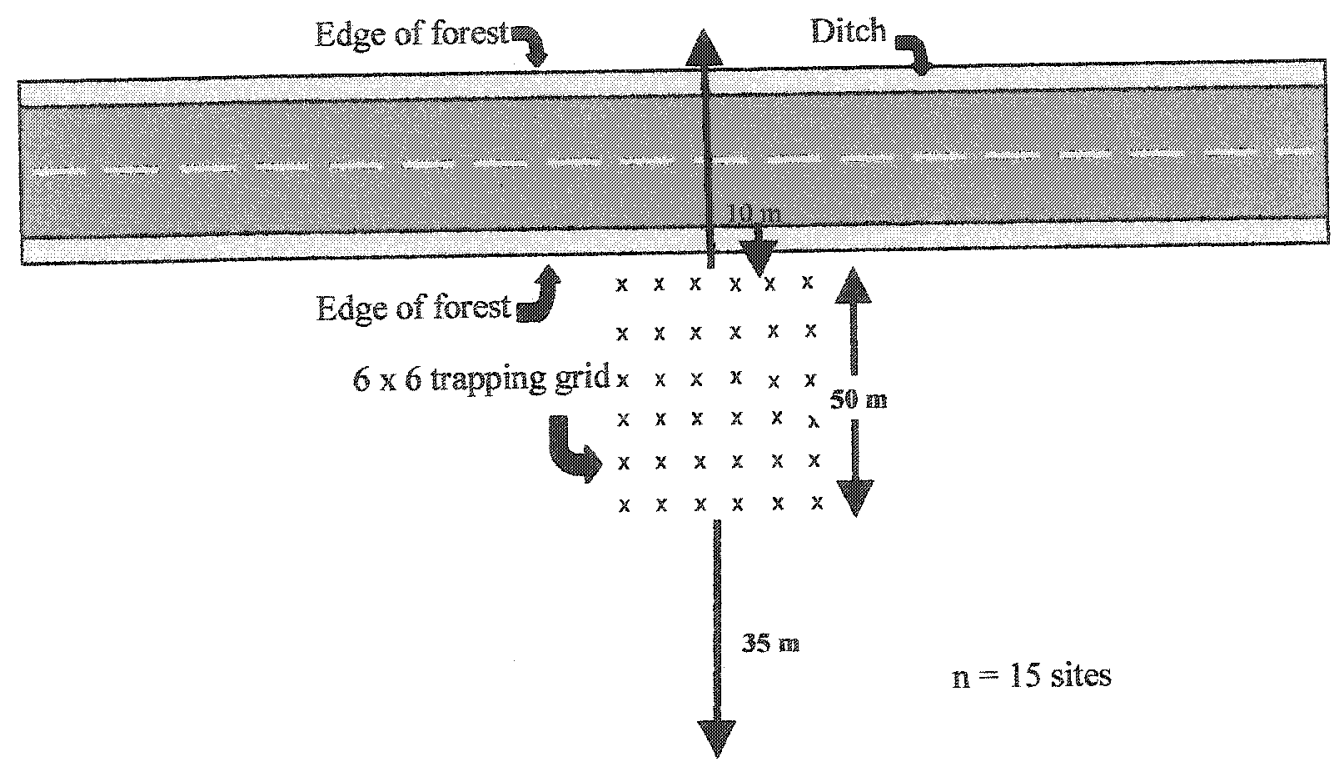

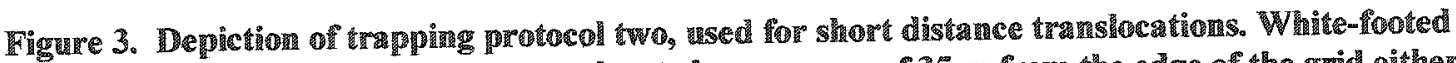
mice and easterm chipmunks were translocated an average of 35 m irom the cdge of the grid either across the road or farther into the forest. The grids were composed of 6 tramsects each of which contained 6 traps separated by $10 \mathrm{~m}$. Every site (m=15) included a $100 \mathrm{~m}$ segment of a 2 lane paved road that did not have culverts, lights, driveways or access roads along its length. Sites were chosem to cover a wide ramge od traffic volumes, from 50 average annual daily traffic (AADT) to 15433 AADT.

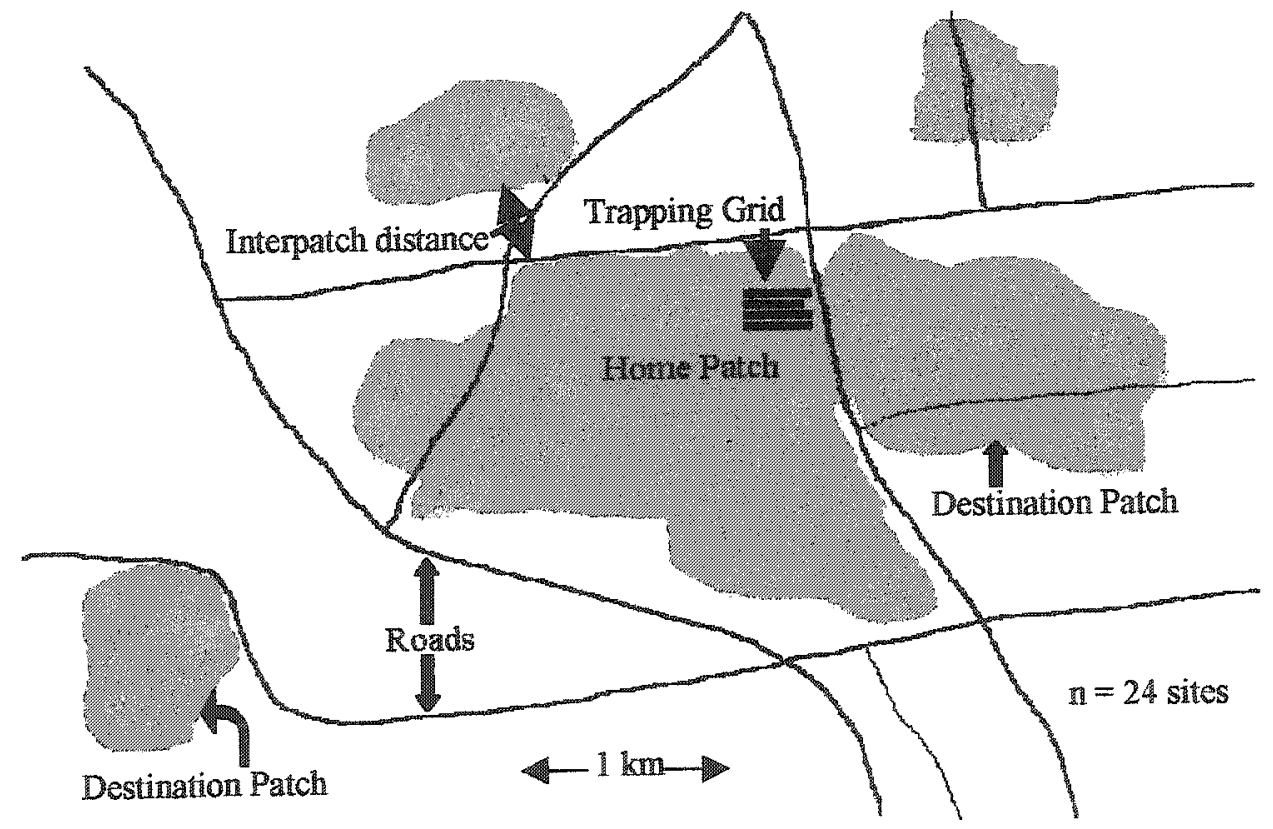

Tigure 4. Depiction of lypothetical landscape with "home" patch for trapping protocol three. Four tramsects of 18 traps were ser up in home patch. White-footed mice and chipmunks were tramslocated from 20 home patehes in 2000 and 4 home patches in 2003 to desthation patches in the

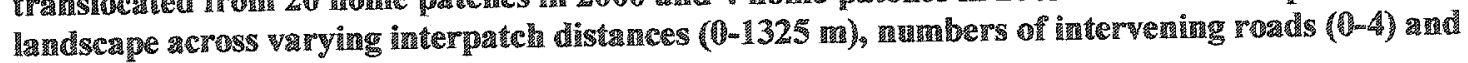
traffic volumes (0-15433 ADT). 


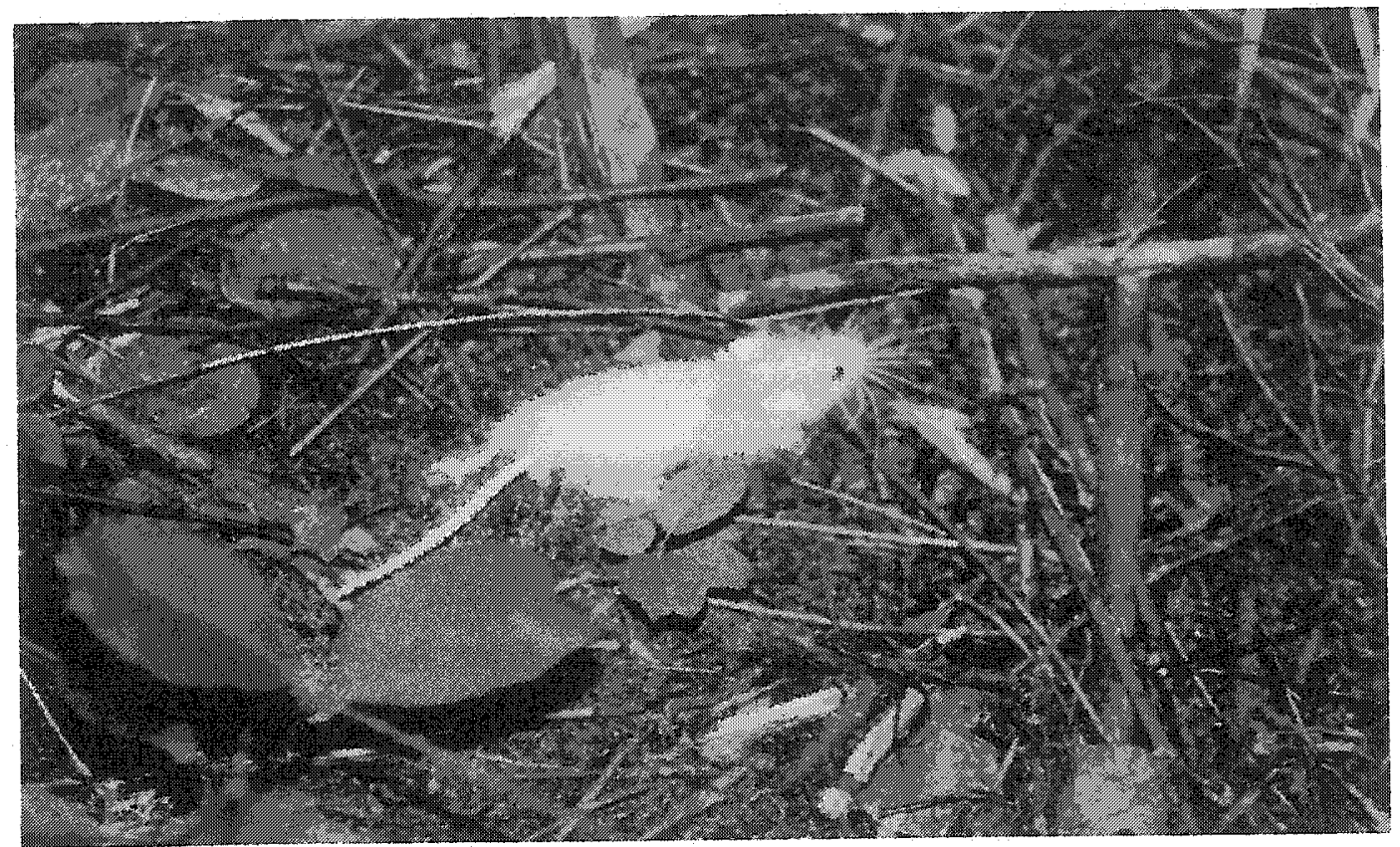

Figure 5. White-footed mouse covered with fluorescent powder.

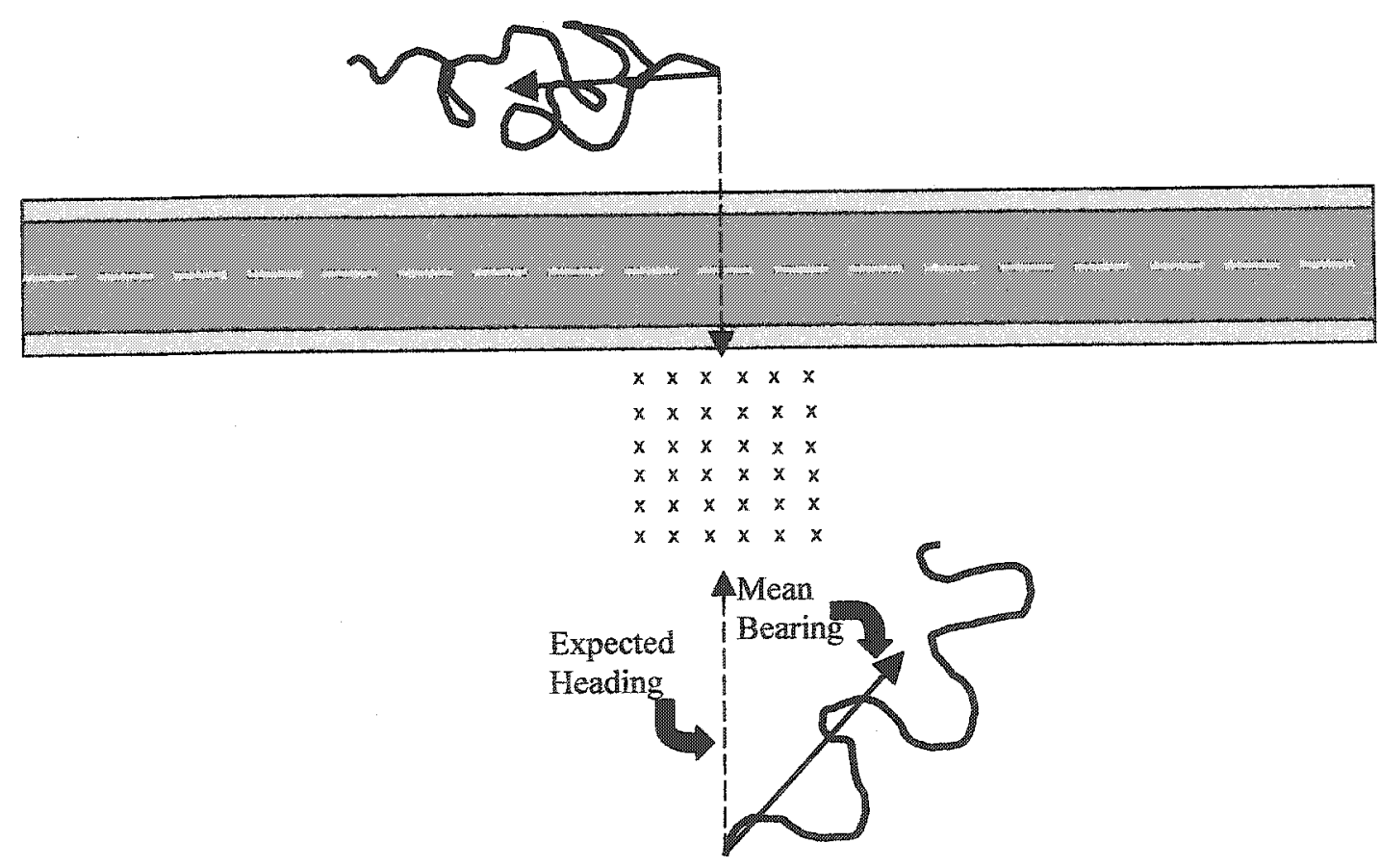

Figure 6. Hypothetical paths of animals translocated within continuous forest and across roads. The mean bearing is calculated using the headings marked of in the path. We expected that animals would have a desire to return to their home range, and so should be oriented back towards the grid. Therefore, the expected relative heading for animals translocated across roads was 180 degrees while the expected relative heading for animals translocated on the same side of the road was 360 degrees. 


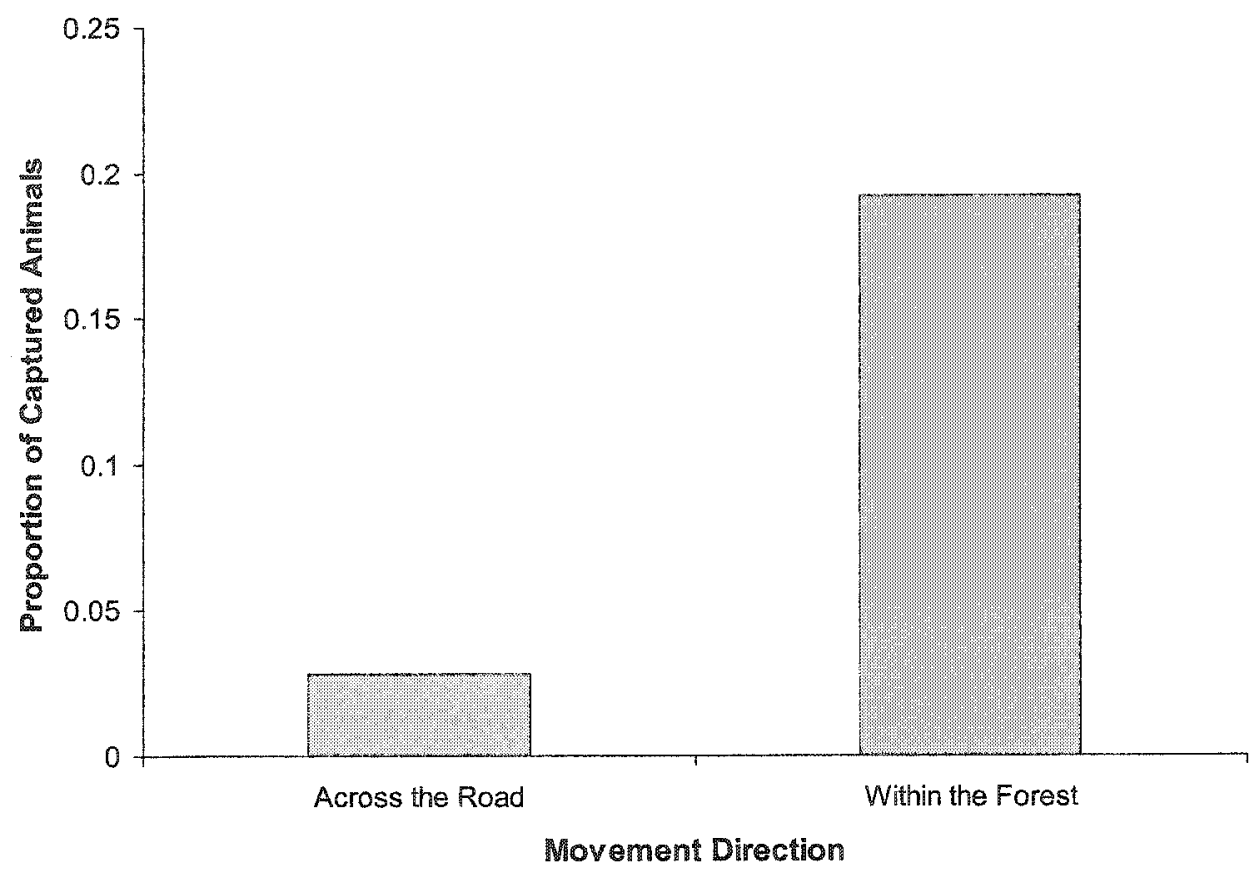

Figure 7. Comparison of the number of animals that spontaneously moved across roads and within continuous forest. Of the 240 total small mammals trapped, 41 moved between grids. The proportion of animals that moved between roadside grids (5/177) was significantly less than the proportion that moved between grids on the same side of the road $\left(36 / 188 ; \mathrm{df}=1, \chi^{2}=24.4, p<0.0001\right)$. Each of the 13 sites used in this portion of the study was live-trapped for 6 nights. 

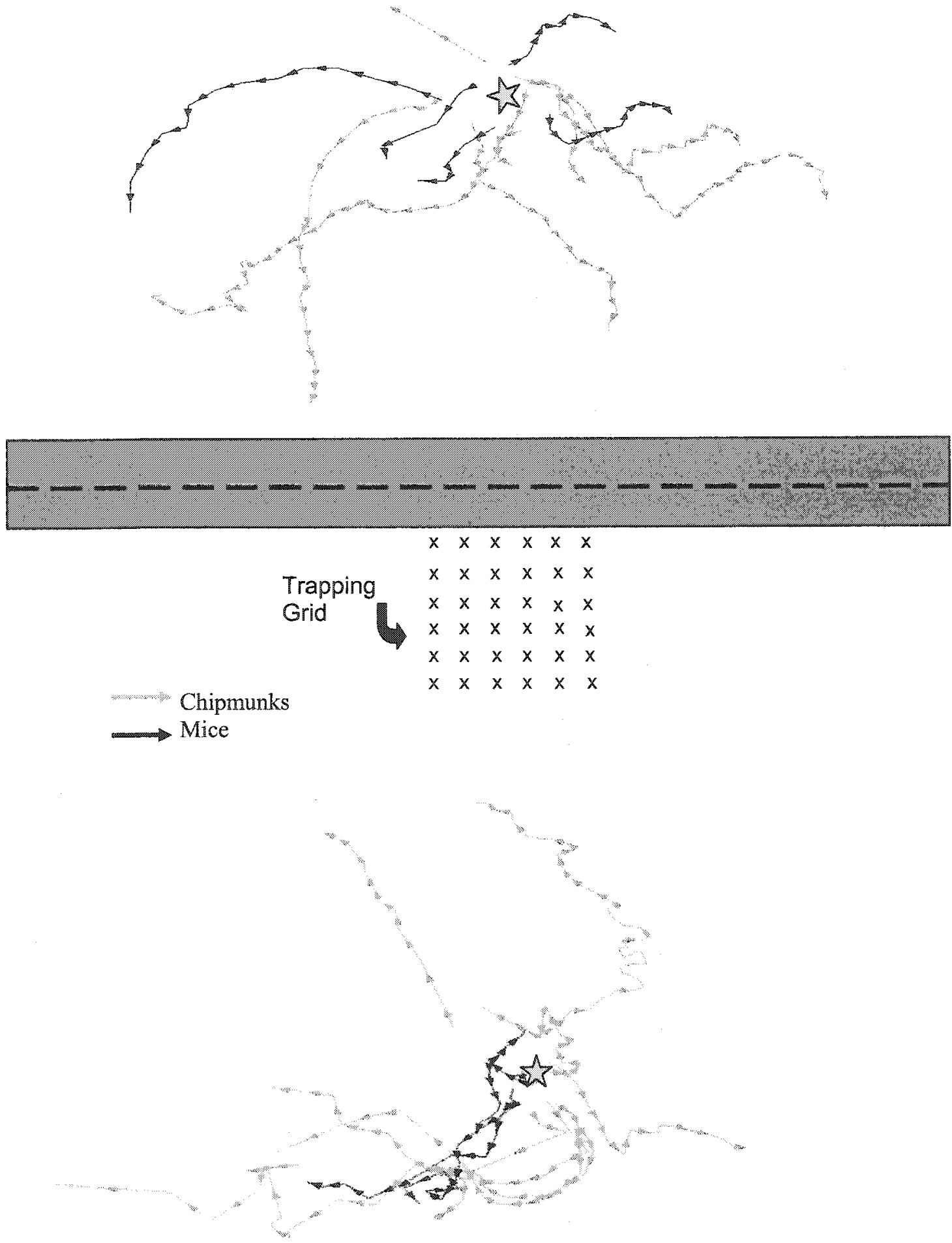

Figure 8. The paths of 4 mice and 8 chipmunks that were translocated across roads, and 6 mice and 7 chipmunks that were translocated within the continuous forest patch from 15 sites. Chipmunks are notated by a light grey line, mice by a black line. Stars represent the release point. Paths do not start directly from the stars because the first $5 \mathrm{~m}$ of the paths were removed from analysis. 


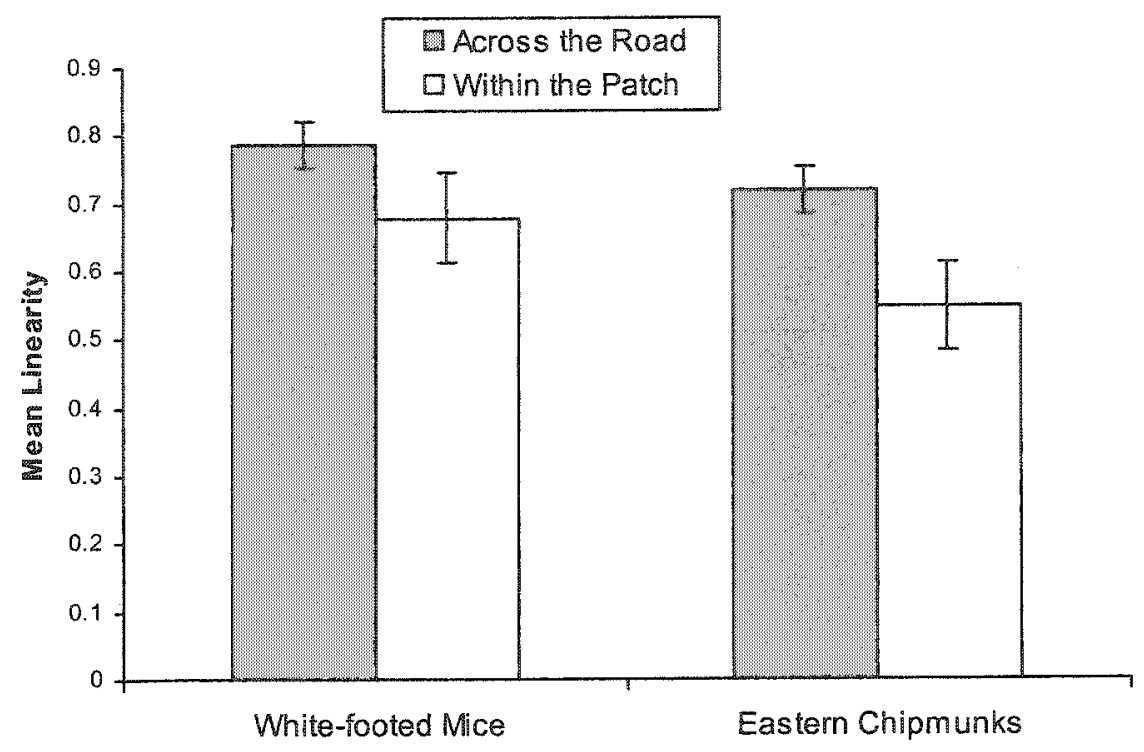

Figure 9. Comparison of the mean linearity for the paths of white-footed mice and eastern chipmunks that were trapped during protocol two ( 1 st. error). We analysed the paths of 4 mice and 8 chipmunks that were translocated across roads, and 6 mice and 7 chipmunks that were translocated within the continuous forest patch. Both species of small mammals moved across roads had significantly straighter paths than did those translocated within continuous forests when analysed separately (mice: $\mathfrak{t}=1.28, d f=8, p=0.11$; chipmunks: $t=2.31, d f=13, p=0.02$ ) and combined $(t=2.8, d f=23, p=0.005)$.

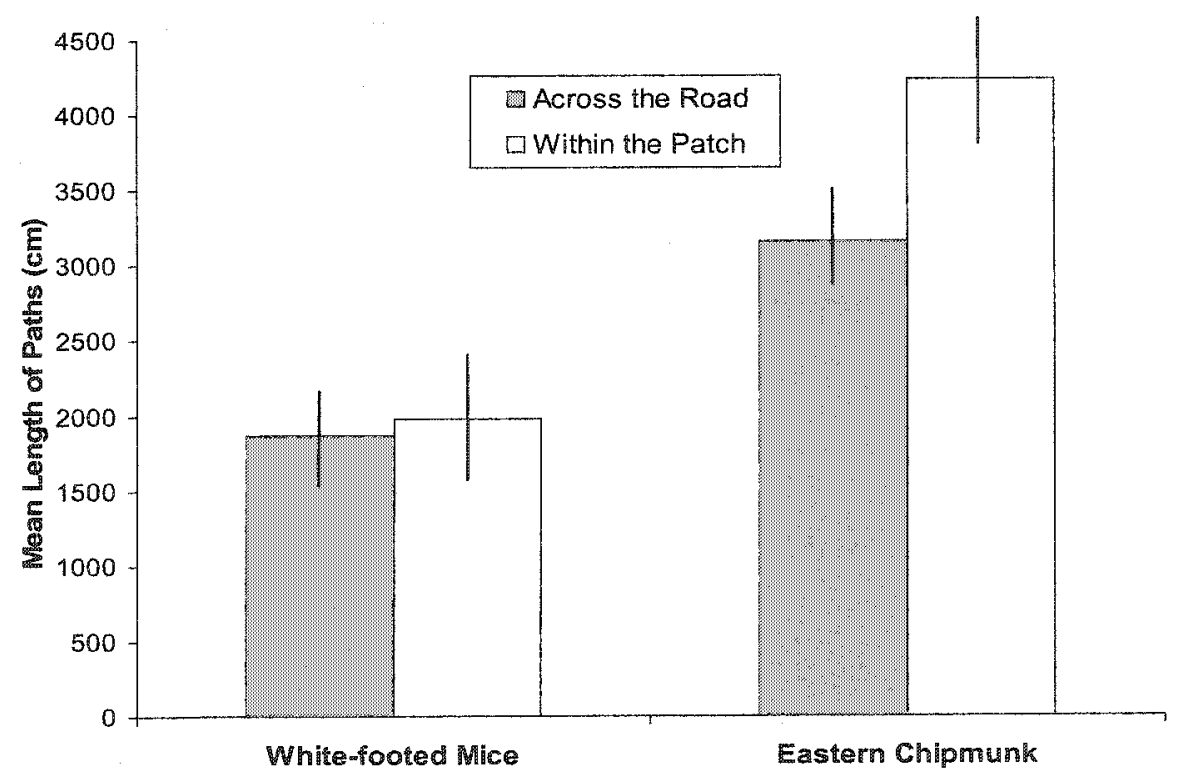

Figure 10. Comparison of the mean length of paths for powdered mice and chipmunks translocated across roads and within continuous forest ( \pm st. error). We analysed the paths of 4 mice and 8 chipmunks that were translocated across roads, and 6 mice and 7 chipmunks that were translocated within the continuous forest patch. There was no difference in the length of the paths of animals translocated across roads and continuous forests $(t=1.04, d f=23, p=0.15)$, regardless of species (i.e, chipmunks: $t=0.82, d f=13, p=0.21$, mice: $t=0.15, d f=8, p=0.44$ ). 


\section{Cxpected orientation of amimals}

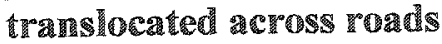

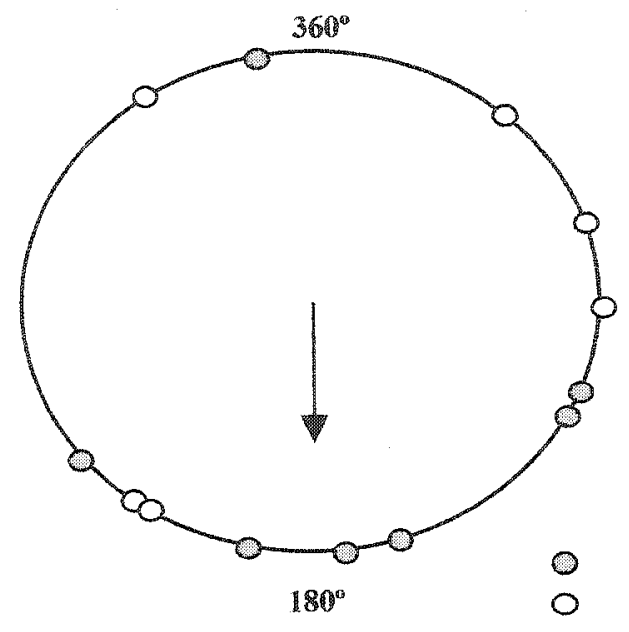

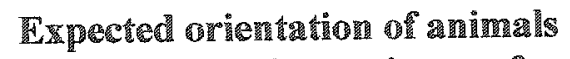
translocated within contin

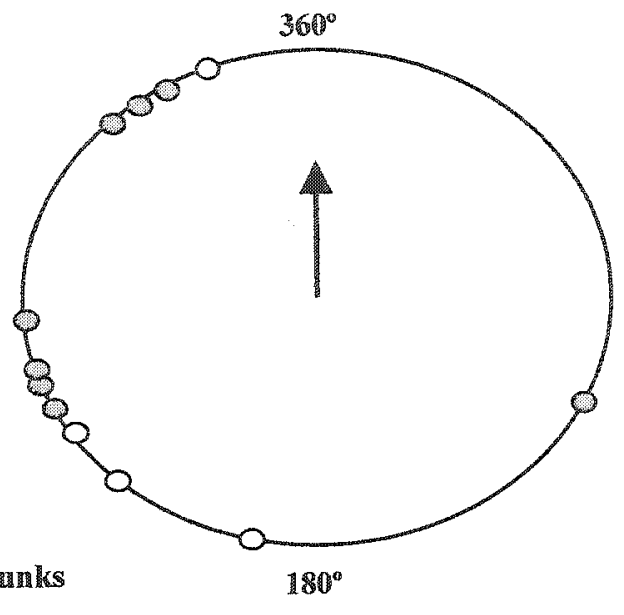

Figure 11. Mean bearings of animals translocated across the roads and within continuous forest. We expected animals to orient to their home range after translocation, and so expected animals to orient themselves relative to the trapping grid. We arbitrarily chose 180 degrees for animals translocated across the roads and 360 degrees for amimals tramsiocated within continuous forest because of the opposite nature of the translocations (see Figure 6). White circles are mean bearings for mice, blue are the mean bearings for chipmunks. There was no significant difference in the orientations (df = $23, \mathfrak{t}=1.10, p=0.28$ ).

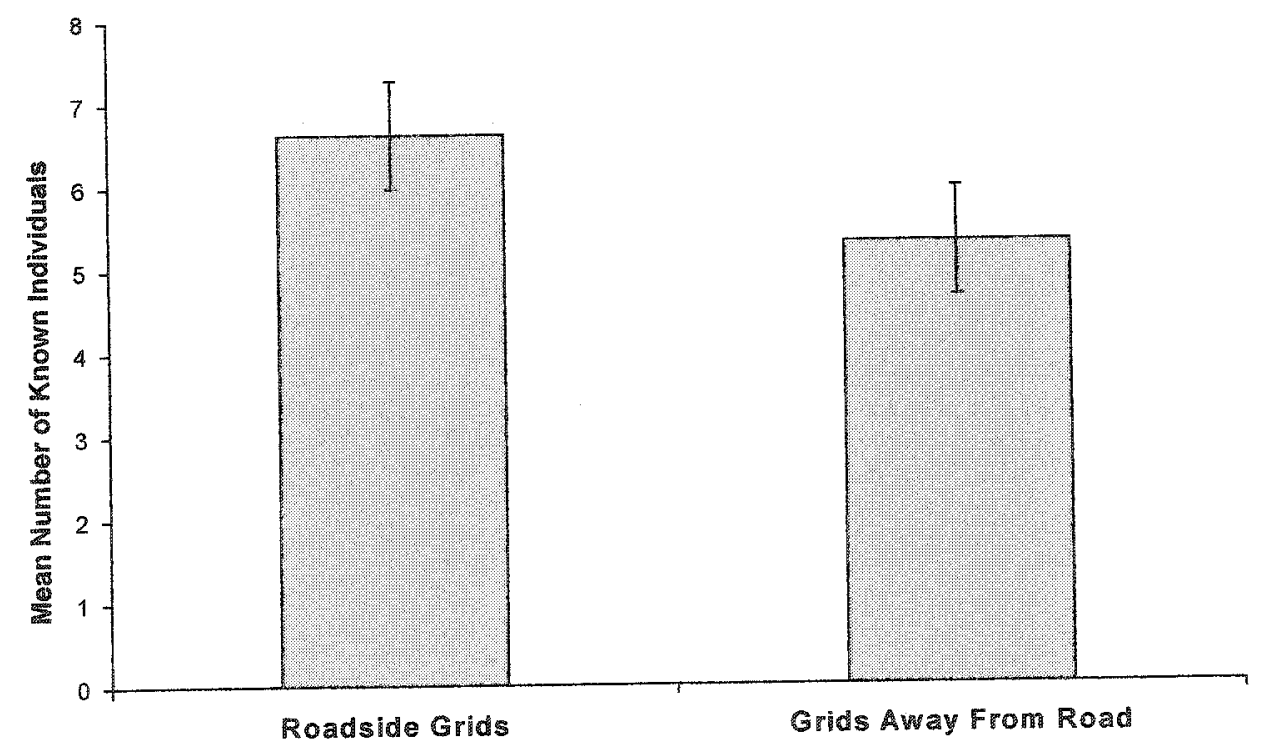

Figure 12. Comparison of the number of individuals trapped in roadside and interior grids ( \pm st. error). We compared the number of animals that were captured in the roadside grids and grids farther away from the road for the 13 sites of protocol one using paired t-tests. There was no significant effect of grid location on the number of animals captured, regardless of site (Figure $12 ; t=$ $1.79, d f=12, p=0.099)$, although roadside grids tended to have higher capture rates $(6.61 \pm 0.14$ individuals) than forest interior grids $(5.3 \pm 0.13$ individuals). 


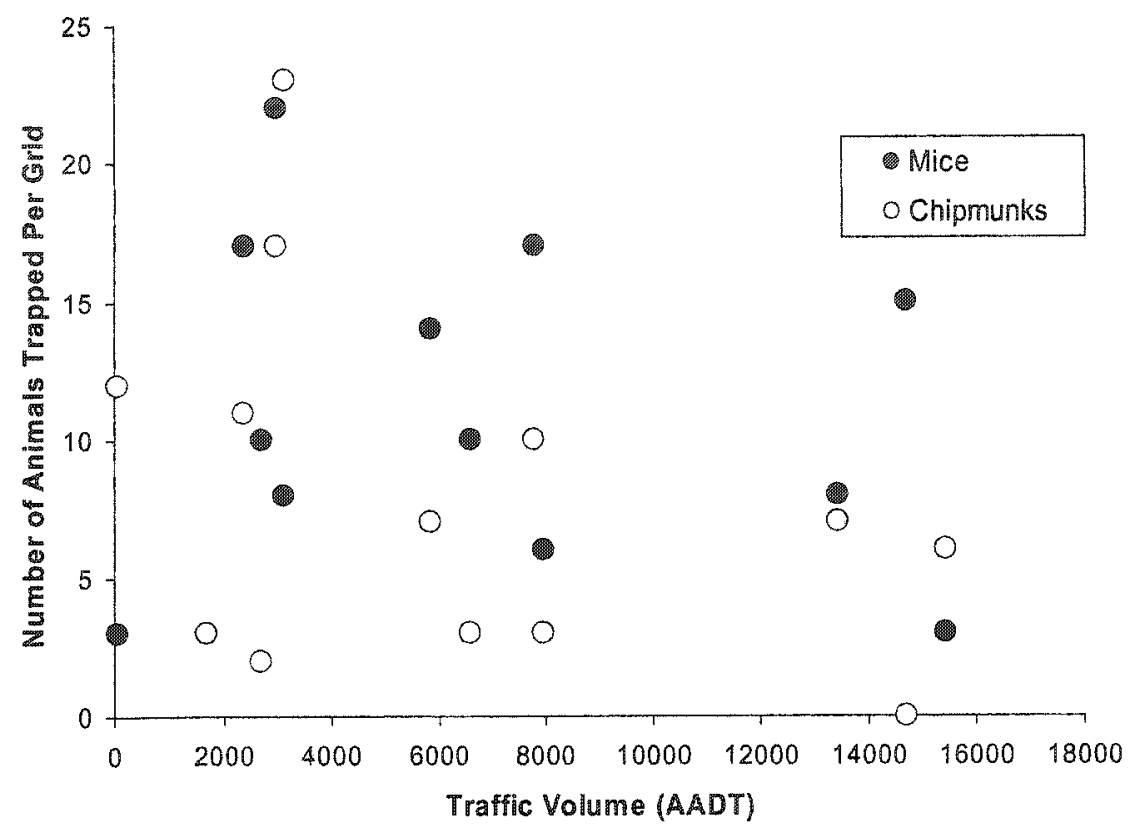

Figure 13. The effect of traffic volume (annual average daily traffic) on the number of mice and chipmunks trapped. There was no effect of traffic volume on the number of animals trapped in the sites $\left(F_{1,12}=1.16, p=0.30\right)$, even when chipmunks $\left(F_{1,12}=2.32, p=0.16\right)$ and white-footed mice $\left(F_{1,12}=\right.$ $0.034, p=0.86$ ) were analysed separately.

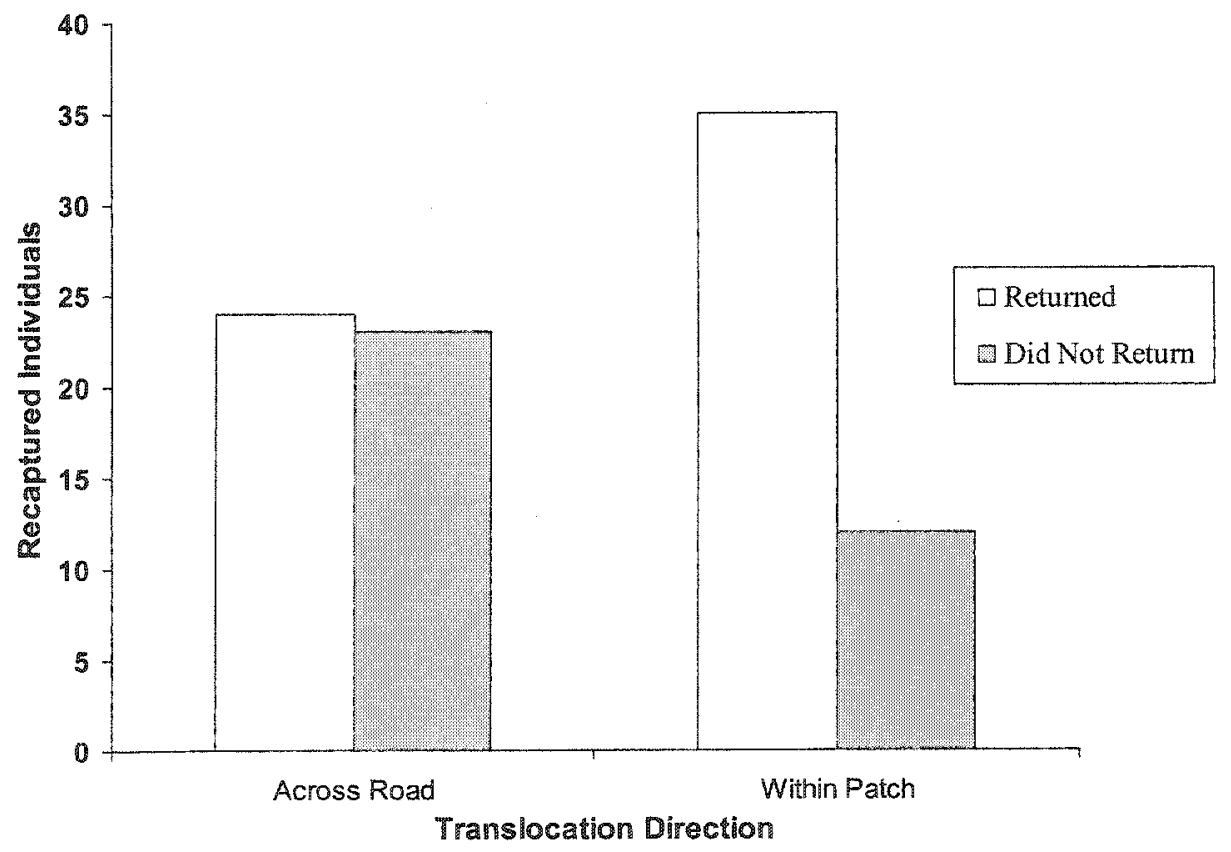

Figure 14. Comparison in the number of animals that were recaptured when translocated across roads and within continuous forest. Ninety one animals were translocated from 15 sites. Although over $53 \%$ of animals translocated across roads successfully returned from translocation, movement success was significantly higher when animals were translocated within continuous forest $\left(\chi^{2}=7.28\right.$, $p=0.0070$ ) than across roads. 


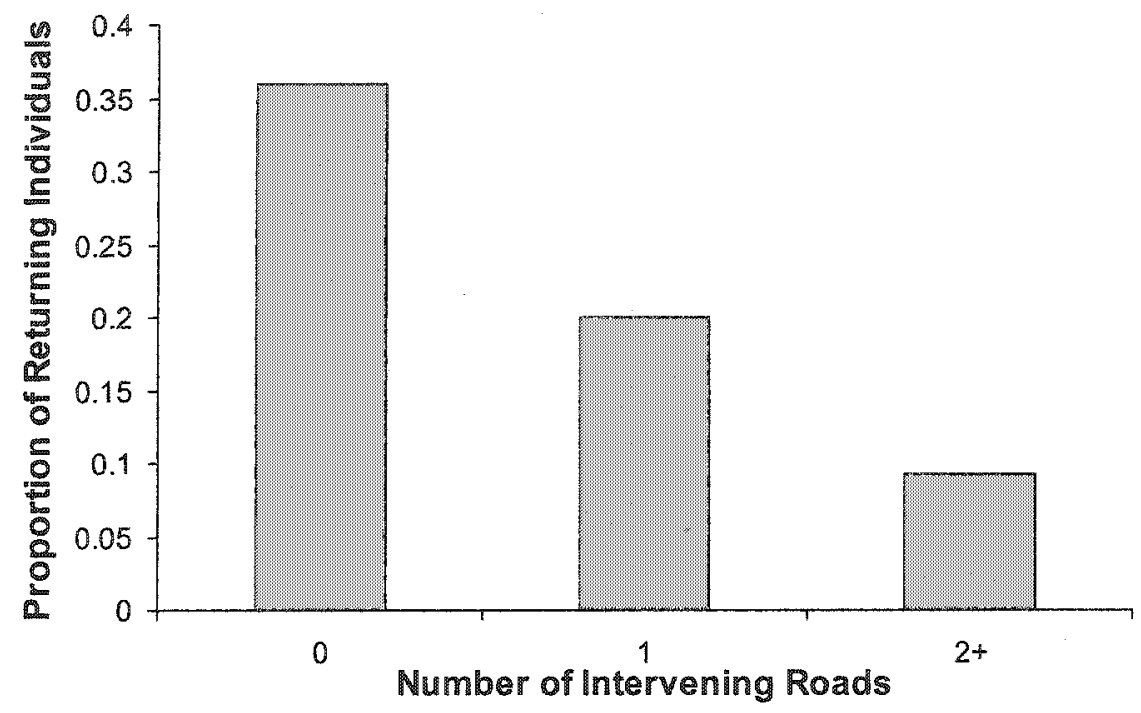

Figure 15. The effect of the number of roads between home and destination patches on the number of animals recaptured from long distance translocations in protocol three. We translocated $312 \mathrm{small}$ mammals from 24 home patches to destination forest patches over varying numbers of intervening roads. The proportion of returning individuals from translocations decreased by about 50 percent for every road than was placed between two forest patches. There was a significant, negative effect of intervening roads on small mammal movement success $\left(d f=1\right.$, Wald $\left.\chi^{2}=14.88, p<0.0001\right)$.

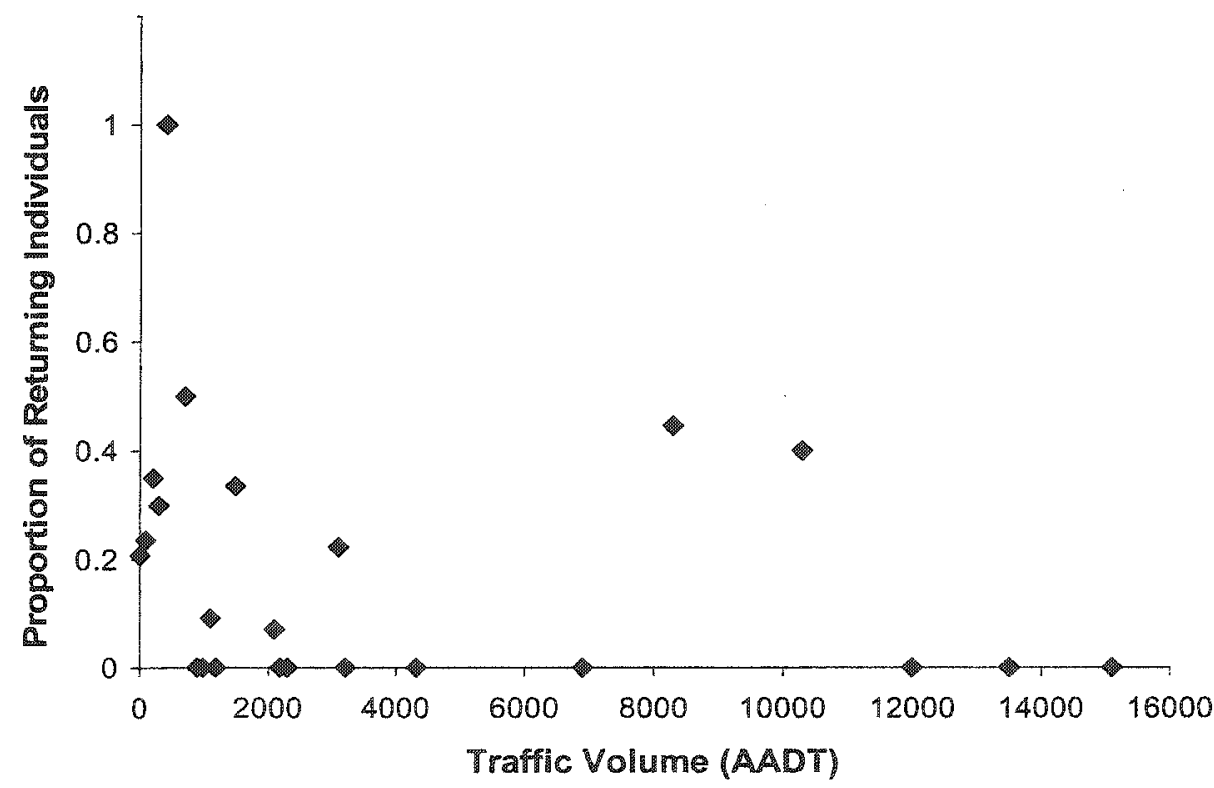

Figure 16. The effect of traffic volume (AAD) on the proportion of animals recaptured from long distance translocations. We translocated 312 small mammals from 24 home patches to destination patches over varying traffic volumes. The proportion of individuals returning from translocations tended to decrease with increasing traffic volume $\left(d f=1\right.$, Wald $\left.\chi^{2}=2.9, p=0.084\right)$. 
Appendix A. Data for trapping protocol one. Locations are mames of sites used in the summers of 2002 and 2003 . Dates are for the first time that an individual was trapped. Traffic volumes are annual average daily traffic (AADT) volumes as estimated by the City of Ottawa (2002). ML: Mustela erminae, MP: Microtus penusylvamicus, PL: Peromyscus leucopus, TH: Tamiascurius huadsonicus, TS: Tamias scurius, CG: Clethrionomys gapperi, SF: Sorex fumeus, NI: Napaeozapus inssignis, GS: Glaucomys sabrinus, SC, Sciumus carolinemsis, SC: Sorex cinerex. Unmarked individuals trapped on the final day at each site were not marked and are labelled as $n$ in the table. Recaptured indicates the imdividual was recaptured at least one more time the 6 nights of a trapping session. Where indicates what direction an animal moved: within the continuous forest or across roads.

\begin{tabular}{|c|c|c|c|c|c|c|c|c|c|}
\hline Location & Date & $\begin{array}{l}\text { Traffic } \\
\text { Volume }\end{array}$ & Grid & $\mathrm{Tag}$ & Species & Sex & Mass & Recaptured & Where \\
\hline WHC 2002 & $08 / 05 / 02$ & 13423 & Roadsidel & $\mathrm{nm}$ & PL & $\mathrm{M}$ & 22 & 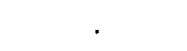 & . \\
\hline WHC 2002 & $08 / 05 / 02$ & 13423 & Roadside2 & $\mathrm{nm}$ & $\mathrm{PL}$ & $\mathrm{F}$ & 16 & . & . \\
\hline WHC 2002 & $08 / 05 / 02$ & 13423 & Roadside2 & 1033 & TS & $\mathrm{M}$ & 100 & $\mathrm{Y}$ & . \\
\hline WHC 2002 & $08 / 05 / 02$ & 13423 & Roadside2 & 1099 & TS & $\mathrm{M}$ & 92 & $Y$ & . \\
\hline WHC 2002 & $09 / 05 / 02$ & 13423 & Interior & 1030 & $\mathrm{CG}$ & $\mathrm{M}$ & 22 & . & 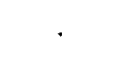 \\
\hline WHC 2002 & $09 / 05 / 02$ & 13423 & Interior & 1090 & $\mathrm{CG}$ & M & 20 & $Y$ & 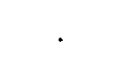 \\
\hline WHC 2002 & $09 / 05 / 02$ & 13423 & Interior & 1094 & $\mathrm{CG}$ & F & 22 & . & 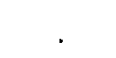 \\
\hline WHC 2002 & $09 / 05 / 02$ & 13423 & Interior & 1089 & $\mathrm{PL}$ & $\mathrm{M}$ & 19 & . & 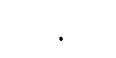 \\
\hline WHC 2002 & $09 / 05 / 02$ & 13423 & Roadside2 & 1406 & $\mathrm{TH}$ & $\mathbb{F}$ & 190 & $\mathrm{Y}$ & . \\
\hline WHC 2002 & $09 / 05 / 02$ & 13423 & Roadside2 & $\mathrm{nm}$ & TH & . & . & . & 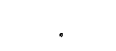 \\
\hline WHC 2002 & $10 / 05 / 02$ & 13423 & Interior & $\mathrm{nm}$ & CG & & . & . & . \\
\hline WHC 2002 & $10 / 05 / 02$ & 13423 & Roadside2 & 1175 & $\mathrm{PL}$ & $\mathrm{F}$ & 18 & . & . \\
\hline WHC 2002 & $10 / 05 / 02$ & 13423 & Roadside2 & $\mathrm{nm}$ & PL & . & . & . & . \\
\hline WHC 2002 & $10 / 05 / 02$ & 13423 & Interior & $\mathrm{nm}$ & $\mathrm{PL}$ & . & 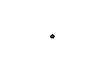 & . & . \\
\hline WHC 2002 & $10 / 05 / 02$ & 13423 & Roadside2 & $\mathrm{nm}$ & $\mathrm{TH}$ & - & & . & . \\
\hline WHC 2002 & $10 / 05 / 02$ & 13423 & Roadside2 & 1116 & TS & $\mathrm{M}$ & 100 & . & . \\
\hline WHC 2002 & $10 / 05 / 02$ & 13423 & Roadside2 & 1117 & TS & $\mathrm{M}$ & 90 & $\mathrm{Y}$ & . \\
\hline WHC 2002 & $11 / 05 / 02$ & 13423 & Interior & $\mathrm{nm}$ & GS & & & . & . \\
\hline WHC 2002 & $11 / 05 / 02$ & 13423 & Roadside 1 & 1006 & PL & . & & . & . \\
\hline WHC 2002 & $11 / 05 / 02$ & 13423 & Roadsidel & 1059 & TS & $\mathrm{M}$ & 95 & . & . \\
\hline WHC 2002 & $12 / 05 / 02$ & 13423 & Roadside1 & 1053 & $\mathrm{PL}$ & $\mathrm{M}$ & 25 & . & . \\
\hline WHC 2002 & $12 / 05 / 02$ & 13423 & Roadside2 & $\mathrm{nm}$ & TS & $\mathrm{M}$ & 100 & . & \\
\hline WHC 2002 & $12 / 05 / 02$ & 13423 & Interior & $\mathrm{nm}$ & TS & . & . & . & . \\
\hline Davidson & $20 / 05 / 02$ & 1670 & Roadside2 & 1142 & $\mathrm{TH}$ & M & 196 & . & . \\
\hline Davidson & $20 / 05 / 02$ & 1670 & Roadside2 & 1165 & $\mathrm{TH}$ & $F$ & 206 & $\mathrm{Y}$ & . \\
\hline Davidson & $20 / 05 / 02$ & 1670 & Roadside1 & $\mathrm{nm}$ & TS & $\mathrm{M}$ & 110 & . & . \\
\hline Davidson & $21 / 05 / 02$ & 1670 & Interior & 1029 & $\mathrm{CG}$ & $\mathrm{M}$ & 30 & . & . \\
\hline Davidson & $22 / 05 / 02$ & 1670 & Interior & 1007 & $\mathrm{CG}$ & $\mathrm{M}$ & 25 & . & . \\
\hline Davidson & $22 / 05 / 02$ & 1670 & Interior & $\mathrm{nm}$ & $C G$ & $\mathrm{~F}$ & 20 & . & . \\
\hline Davidson & $22 / 05 / 02$ & 1670 & Roadside2 & $\mathrm{nm}$ & $\mathrm{SF}$ & M & . & . & . \\
\hline Davidson & $22 / 05 / 02$ & 1670 & Roadside1 & 1088 & $\mathrm{TH}$ & $\mathrm{F}$ & 170 & Y & within \\
\hline Davidson & $24 / 05 / 02$ & 1670 & Roadside2 & 1185 & TH & $\mathrm{M}$ & 178 & $Y$ & . \\
\hline Davidson & $24 / 05 / 02$ & 1670 & Roadside1 & 1021 & PL & $\mathrm{M}$ & 25 & . & . \\
\hline Davidson & $24 / 05 / 02$ & 1670 & Roadside2 & $\mathrm{nm}$ & $\mathrm{SC}$ & . & . & . & . \\
\hline Davidson & $24 / 05 / 02$ & 1670 & Roadside2 & 1158 & TH & $\mathrm{M}$ & 176 & $Y$ & \\
\hline
\end{tabular}


Appendix A cont...

\begin{tabular}{|c|c|c|c|c|c|c|c|c|c|}
\hline \multirow{2}{*}{ Location } & \multicolumn{3}{|c|}{ Traffic } & \multirow[b]{2}{*}{ Tag } & \multirow[b]{2}{*}{ Species } & \multirow[b]{2}{*}{ Sex } & \multirow[b]{2}{*}{ Mass } & \multirow[b]{2}{*}{ Recaptured } & \multirow[b]{2}{*}{ Where } \\
\hline & Date & Volume & Grid & & & & & & \\
\hline Davidson & $24 / 05 / 02$ & 1670 & Interior & 1009 & TS & $\bar{M}$ & 90 & 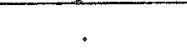 & - \\
\hline Davidson & $25 / 05 / 02$ & 1670 & Roadsidel & 1081 & PL & $\mathrm{M}$ & 23 & . & . \\
\hline Davidson & $25 / 05 / 02$ & 1670 & Interior & $\mathrm{nm}$ & $\mathrm{TH}$ & . & . & . & . \\
\hline Davidson & $25 / 05 / 02$ & 1670 & Interior & 1041 & TS & . & . & Y & . \\
\hline Mer Bleu & $31 / 05 / 02$ & 47 & Roadside2 & 1124 & $\mathrm{MP}$ & $\mathrm{M}$ & 24 & . & . \\
\hline Mer Bleu & $31 / 05 / 02$ & 47 & Roadside2 & 1114 & $\mathrm{PL}$ & $\mathrm{M}$ & 24 & $\dot{\mathrm{Y}}$ & . \\
\hline Mer Bleu & $31 / 05 / 02$ & 47 & Roadside2 & 1133 & TS & $\mathrm{F}$ & 105 & $Y$ & across \\
\hline Mer Bleu & $01 / 06 / 02$ & 47 & Roadsidel & $\mathrm{nm}$ & $\mathrm{ME}$ & . & 112 & . & . \\
\hline Mer Bleu & $01 / 06 / 02$ & 47 & Roadside2 & $\mathrm{nm}$ & PL & F & 24 & . & \\
\hline Mer Bleu & $01 / 06 / 02$ & 47 & Roadsidel & 1056 & TS & F & 105 & Y & within \\
\hline Mer Bleu & $01 / 06 / 02$ & 47 & Roadside2 & $\mathrm{nm}$ & TS & $\mathrm{F}$ & 108 & . & . \\
\hline Mer Bleu & $02 / 06 / 02$ & 47 & Roadside2 & 1093 & PL & $\mathrm{M}$ & 30 & . & . \\
\hline Mer Bleu & $02 / 06 / 02$ & 47 & Roadside2 & 1153 & TS & $\mathrm{M}$ & 120 & . & \\
\hline Mer Bleu & $02 / 06 / 02$ & 47 & Roadside 2 & $\mathrm{~nm}$ & TS & $\mathrm{M}$ & 100 & . & . \\
\hline Mer Bleu & $03 / 06 / 02$ & 47 & Roadsidel & $\mathrm{nm}$ & TS & $\mathrm{M}$ & 115 & . & . \\
\hline Mer Bleu & $04 / 06 / 02$ & 47 & Roadside2 & $\mathrm{nm}$ & $\mathrm{ME}$ & & 194 & . & . \\
\hline Mer Bleu & $04 / 06 / 02$ & 47 & Roadside2 & $\mathrm{nm}$ & MP & $\mathrm{F}$ & 20 & . & . \\
\hline Mer Bleu & $04 / 06 / 02$ & 47 & Roadside 2 & $\mathrm{~nm}$ & TH & 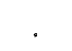 & . & . & . \\
\hline Mer Bleu & $04 / 06 / 02$ & 47 & Interior & 1009 & $\mathrm{TS}$ & & & $Y$ & within \\
\hline Mer Bleu & $04 / 06 / 02$ & 47 & Roadside2 & 1155 & TS & $\mathrm{M}$ & 112 & $\mathrm{Y}$ & . \\
\hline Mer Bleu & $04 / 06 / 02$ & 47 & Roadside2 & 1164 & TS & $\mathrm{M}$ & 110 & $Y$ & . \\
\hline Mer Bleu & $05 / 06 / 02$ & 47 & Roadside1 & 1039 & TS & $\mathrm{M}$ & 120 & $\mathrm{Y}$ & within \\
\hline Mer Bleu & $05 / 06 / 02$ & 47 & Roadside2 & 1069 & TS & $\mathrm{F}$ & 125 & . & . \\
\hline Mer Bleu & $06 / 06 / 02$ & 47 & Interior & 1064 & TS & $\mathrm{M}$ & 100 & Y & within \\
\hline Davidson & $08 / 06 / 02$ & 1670 & Roadside2 & $\mathrm{nm}$ & PL & $\mathrm{F}$ & 102 & . & 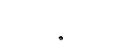 \\
\hline Slack & $22 / 06 / 02$ & 2677 & Roadside1 & 1027 & PL & $\mathrm{F}$ & 30 & . & \\
\hline Slack & $22 / 06 / 02$ & 2677 & Interior & 1032 & PL & $\mathrm{M}$ & . & $Y$ & \\
\hline Slack & $22 / 06 / 02$ & 2677 & Interior & 1068 & $\mathrm{PL}$ & $\mathrm{F}$ & 25 & $\mathrm{Y}$ & within \\
\hline Slack & $22 / 06 / 02$ & 2677 & Interior & 1011 & $\mathrm{TH}$ & $\mathrm{M}$ & . & . & . \\
\hline Slack & $22 / 06 / 02$ & 2677 & Roadside 2 & 1102 & TH & $\mathrm{M}$ & 204 & Y & . \\
\hline Slack & $22 / 06 / 02$ & 2677 & Roadside2 & $\mathrm{nm}$ & TH & $\mathrm{F}$ & 194 & . & . \\
\hline Slack & $22 / 06 / 02$ & 2677 & Roadside2 & $\mathrm{nm}$ & TH & . & . & . & . \\
\hline Slack & $22 / 06 / 02$ & 2677 & Roadside2 & $\mathrm{nm}$ & TS & $\mathrm{F}$ & 70 & . & . \\
\hline Slack & $23 / 06 / 02$ & 2677 & Interior & 1104 & TH & $\mathrm{M}$ & 205 & . & . \\
\hline Slack & $25 / 06 / 02$ & 2677 & Roadsidel & 1024 & PL & $\mathrm{F}$ & 24 & . & . \\
\hline Slack & $25 / 06 / 02$ & 2677 & Roadside2 & 1166 & PL & $\mathrm{F}$ & 20 & Y & . \\
\hline Slack & $25 / 06 / 02$ & 2677 & Roadside2 & $\mathrm{nm}$ & PL & $\mathrm{F}$ & 42 & . & . \\
\hline Slack & $26 / 06 / 02$ & 2677 & Interior & 1080 & PL & $\mathrm{M}$ & 20 & . & . \\
\hline Slack & $26 / 06 / 02$ & 2677 & Roadside2 & 1131 & TS & $F$ & 92 & $\mathrm{Y}$ & within \\
\hline Slack & $27 / 06 / 02$ & 2677 & Roadside2 & $\mathrm{nm}$ & GS & . & . & . & . \\
\hline Slack & $27 / 06 / 02$ & 2677 & Interior & 2624 & PL & $\mathrm{F}$ & . & . & . \\
\hline Slack & $27 / 06 / 02$ & 2677 & Interior & $\mathrm{nm}$ & SF & . & . & 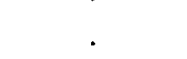 & . \\
\hline Slack & $28 / 06 / 02$ & 2677 & Roadside 2 & $\mathrm{~nm}$ & PL & $\mathrm{M}$ & 20 & . & . \\
\hline Slack & $28 / 06 / 02$ & 2677 & Interior & $\mathrm{nm}$ & PL & $\mathrm{F}$ & 24 & & . \\
\hline Lester & $14 / 07 / 02$ & 7760 & Roadside1 & 617 & $\mathrm{CG}$ & $\mathrm{F}$ & 25 & $Y$ & . \\
\hline Lester & $14 / 07 / 02$ & 7760 & Roadside 2 & 224 & PL & F & 16 & $\mathrm{Y}$ & \\
\hline
\end{tabular}


Appendix A cont...

\begin{tabular}{|c|c|c|c|c|c|c|c|c|c|}
\hline Location & Date & $\begin{array}{l}\text { Traffic } \\
\text { Volume }\end{array}$ & Grid & Tag & Species & Sex & Mass & Recaptured & Where \\
\hline Lester & $14 / 07 / 02$ & 7760 & Roadside2 & 225 & PL & $F$ & 16 & $Y$ & within \\
\hline Lester & $14 / 07 / 02$ & 7760 & Interior & 604 & PL & $\mathrm{M}$ & 25 & $\mathrm{Y}$ & . \\
\hline Lester & $14 / 07 / 02$ & 7760 & Roadsidel & 608 & PL & $\mathbb{F}$ & 25 & . & . \\
\hline Lester & $14 / 07 / 02$ & 7760 & Roadsidel & 219 & TS & $\mathbb{F}$ & 88 & $\mathrm{Y}$ & across \\
\hline Lester & $15 / 07 / 02$ & 7760 & Roadside1 & $\mathrm{nm}$ & $\mathrm{CG}$ & . & 12 & . & . \\
\hline Lester & $15 / 07 / 02$ & 7760 & Interior & 606 & PL & $F$ & 20 & . & . \\
\hline Lester & $15 / 07 / 02$ & 7760 & Roadsidel & 607 & $\mathrm{PL}$ & $\mathrm{M}$ & 20 & Y & . \\
\hline Lester & $15 / 07 / 02$ & 7760 & Roadside1 & 613 & PL & $\mathrm{M}$ & 15 & $Y$ & . \\
\hline Lester & $15 / 07 / 02$ & 7760 & Roadside1 & 603 & $\mathrm{TS}$ & $\mathrm{F}$ & 85 & Y & across \\
\hline Lester & $15 / 07 / 02$ & 7760 & Roadsidel & $\mathrm{nm}$ & TS & & . & . & . \\
\hline Lester & $16 / 07 / 02$ & 7760 & Roadsidel & 296 & $\mathrm{CG}$ & M & 22 & . & . \\
\hline Lester & $16 / 07 / 02$ & 7760 & Interior & $\mathrm{nm}$ & $\mathrm{ME}$ & . & . & . & . \\
\hline Lester & $16 / 07 / 02$ & 7760 & Interior & 221 & $\mathrm{TS}$ & $\mathrm{M}$ & 90 & $Y$ & within \\
\hline Lester & $16 / 07 / 02$ & 7760 & Roadside1 & 611 & TS & $\mathrm{M}$ & 80 & $\mathrm{Y}$ & . \\
\hline Lester & $16 / 07 / 02$ & 7760 & Roadside1 & $\mathrm{nm}$ & TS & $F$ & 112 & . & . \\
\hline Lester & $17 / 07 / 02$ & 7760 & Roadside2 & 258 & $\mathrm{CG}$ & $\mathrm{M}$ & 18 & $\mathrm{Y}$ & . \\
\hline Lester & $17 / 07 / 02$ & 7760 & Roadside2 & 268 & $\mathrm{PL}$ & $\mathrm{F}$ & 24 & . & . \\
\hline Lester & $17 / 07 / 02$ & 7760 & Roadside2 & 277 & PL & $\mathrm{F}$ & 28 & Y & \\
\hline Lester & $17 / 07 / 02$ & 7760 & Roadsidel & 284 & TS & $\mathrm{F}$ & 120 & . & . \\
\hline Lester & $18 / 07 / 02$ & 7760 & Roadside1 & 289 & $\mathrm{CG}$ & . & 26 & . & . \\
\hline Lester & $18 / 07 / 02$ & 7760 & Interior & 96 & $\mathrm{PL}$ & M & 25 & . & . \\
\hline Lester & $18 / 07 / 02$ & 7760 & Roadside2 & 213 & PL & M & 14 & $\mathrm{Y}$ & . \\
\hline Lester & $18 / 07 / 02$ & 7760 & Roadside2 & 285 & $\mathrm{PL}$ & $\mathrm{M}$ & 20 & $\mathrm{Y}$ & . \\
\hline Lester & $18 / 07 / 02$ & 7760 & Roadside2 & $\mathrm{nm}$ & $\mathrm{SC}$ & . & . & . & . \\
\hline Lester & $18 / 07 / 02$ & 7760 & Roadside2 & $\mathrm{nm}$ & $\mathrm{TH}$ & . & . & . & . \\
\hline Lester & $18 / 07 / 02$ & 7760 & Roadside2 & $\mathrm{nm}$ & TH & . & . & & . \\
\hline Lester & $19 / 07 / 02$ & 7760 & Roadsidel & 208 & TS & . & 104 & $\mathrm{Y}$ & . \\
\hline Lester & $19 / 07 / 02$ & 7760 & Roadsidel & 316 & $\mathrm{TS}$ & M & 100 & . & . \\
\hline Lester & $20 / 07 / 02$ & 7760 & Roadside1 & $\mathrm{nm}$ & $\mathrm{CG}$ & $F$ & 30 & . & . \\
\hline Lester & $20 / 07 / 02$ & 7760 & Roadside 1 & 320 & PL & $\mathrm{F}$ & 25 & . & . \\
\hline Lester & $20 / 07 / 02$ & 7760 & Roadside1 & $\mathrm{nm}$ & PL & $\mathrm{F}$ & 18 & . & . \\
\hline Lester & $20 / 07 / 02$ & 7760 & Roadside2 & $\mathrm{nm}$ & PL & . & . & . & . \\
\hline Lester & $20 / 07 / 02$ & 7760 & Roadside2 & $\mathrm{nm}$ & PL & . & 10 & . & . \\
\hline Lester & $20 / 07 / 02$ & 7760 & Roadside2 & $\mathrm{nm}$ & PL & . & 10 & . & . \\
\hline Slack B & $25 / 07 / 02$ & 2923 & Roadside1 & $\mathrm{nm}$ & $\mathrm{CG}$ & $\mathrm{M}$ & 16 & . & . \\
\hline Slack B & $25 / 07 / 02$ & 2923 & Roadside2 & 201 & PL & $\mathrm{F}$ & 32 & $\mathrm{Y}$ & . \\
\hline Slack B & $25 / 07 / 02$ & 2923 & Roadside2 & 207 & $\mathrm{PL}$ & M & 16 & . & . \\
\hline Slack B & $25 / 07 / 02$ & 2923 & Roadside1 & 283 & PL & M & 18 & $\mathrm{Y}$ & . \\
\hline Slack B & $25 / 07 / 02$ & 2923 & Roadside1 & 308 & PL & $\mathrm{F}$ & 25 & $\mathrm{Y}$ & . \\
\hline Slack B & $25 / 07 / 02$ & 2923 & Interior & 313 & $\mathrm{PL}$ & M & 20 & $\mathrm{Y}$ & . \\
\hline Slack B & $25 / 07 / 02$ & 2923 & Interior & 315 & PL & $\mathbf{M}$ & 17 & . & . \\
\hline Slack B & $25 / 07 / 02$ & 2923 & Roadside1 & 322 & PL & $\mathrm{M}$ & 15 & Y & within \\
\hline Slack B & $25 / 07 / 02$ & 2923 & Interior & 330 & PL & . & 26 & . & . \\
\hline Slack B & $25 / 07 / 02$ & 2923 & Roadside2 & $\mathrm{nm}$ & PL & . & 210 & . & . \\
\hline Slack B & $25 / 07 / 02$ & 2923 & Roadsidel & $\mathrm{nm}$ & $\mathrm{SC}$ & . & & . & . \\
\hline Slack B & $25 / 07 / 02$ & 2923 & Interior & $\mathrm{nm}$ & $\mathrm{TH}$ & $\mathrm{M}$ & 98 & & \\
\hline
\end{tabular}


Appendix A cont...

\begin{tabular}{|c|c|c|c|c|c|c|c|c|c|}
\hline Location & Date & $\begin{array}{l}\text { Traffic } \\
\text { Volume }\end{array}$ & Grid & Tag & Species & Sex & Mass & Recaptured & Where \\
\hline Slack B & $25 / 07 / 02$ & 2923 & Roadside2 & 252 & TS & $\mathrm{M}$ & 102 & $\mathrm{Y}$ & \\
\hline Slack B & $25 / 07 / 02$ & 2923 & Roadside2 & 263 & TS & $\mathrm{F}$ & 92 & 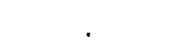 & \\
\hline Slack B & $25 / 07 / 02$ & 2923 & Roadside2 & 288 & TS & $\mathrm{F}$ & 114 & Y & \\
\hline Slack B & $25 / 07 / 02$ & 2923 & Interior & 323 & TS & $\mathbb{F}$ & 90 & - & . \\
\hline Slack B & $26 / 07 / 02$ & 2923 & Roadside2 & 290 & PL & $\mathrm{F}$ & 26 & - & \\
\hline Slack B & $26 / 07 / 02$ & 2923 & Interior & 309 & PL & F & 25 & Y & within \\
\hline Slack B & $26 / 07 / 02$ & 2923 & Interior & 312 & PL & M & 25 & Y & . \\
\hline Slack B & $26 / 07 / 02$ & 2923 & Roadside 1 & 314 & PL & $\mathrm{M}$ & . & Y & . \\
\hline Slack B & $26 / 07 / 02$ & 2923 & Roadside2 & 254 & TS & $\mathrm{F}$ & 100 & Y & . \\
\hline Slack B & $27 / 07 / 02$ & 2923 & Roadside2 & 279 & $\mathrm{CG}$ & . & 17 & . & . \\
\hline Slack B & $27 / 07 / 02$ & 2923 & Roadside2 & 259 & PL & $\mathbb{F}$ & 27 & . & . \\
\hline Slack B & $27 / 07 / 02$ & 2923 & Roadside1 & 309 & PL & F & . & Y & within \\
\hline Slack B & $27 / 07 / 02$ & 2923 & Roadside2 & $\mathrm{nm}$ & PL & $\mathrm{F}$ & 10 & . & . \\
\hline Slack B & $27 / 07 / 02$ & 2923 & Roadside2 & $\mathrm{nm}$ & TH & . & 95 & . & . \\
\hline Slack B & $27 / 07 / 02$ & 2923 & Roadsidel & 302 & TS & $\mathrm{M}$ & 80 & . & \\
\hline Slack B & $27 / 07 / 02$ & 2923 & Roadside1 & 318 & TS & $\mathrm{F}$ & 90 & Y & within \\
\hline Slack B & $28 / 07 / 02$ & 2923 & Roadside2 & 230 & $\mathrm{CG}$ & F & 25 & . & \\
\hline Slack B & $28 / 07 / 02$ & 2923 & Roadsidel & 499 & $C G$ & M & 21 & . & \\
\hline Slack B & $28 / 07 / 02$ & 2923 & Roadside2 & $\mathrm{nm}$ & $\mathrm{CG}$ & F & 20 & . & . \\
\hline Slack B & $28 / 07 / 02$ & 2923 & Roadside2 & 217 & PL & F & 21 & Y & . \\
\hline Slack B & $28 / 07 / 02$ & 2923 & Roadside2 & 291 & PL & M & 18 & . & . \\
\hline Slack B & $28 / 07 / 02$ & 2923 & Roadside2 & 220 & TS & $\mathrm{F}$ & 93 & . & . \\
\hline Slack B & $28 / 07 / 02$ & 2923 & Roadsidel & 518 & TS & . & . & Y & . \\
\hline Slack B & $28 / 07 / 02$ & 2923 & Roadside1 & 602 & TS & $\mathrm{M}$ & 93 & Y & . \\
\hline Slack B & $29 / 07 / 02$ & 2923 & Interior & 304 & PL & $\mathrm{F}$ & 15 & . & . \\
\hline Slack B & $29 / 07 / 02$ & 2923 & Roadside1 & 325 & PL & M & 25 & Y & \\
\hline Slack B & $29 / 07 / 02$ & 2923 & Interior & 292 & TS & $\mathrm{M}$ & 95 & Y & within \\
\hline Slack B & $30 / 07 / 02$ & 2923 & Roadside1 & 310 & $\mathrm{CG}$ & $\mathrm{M}$ & 20 & . & . \\
\hline Slack B & $30 / 07 / 02$ & 2923 & Roadsidel & 450 & $\mathrm{CG}$ & $\mathrm{F}$ & 21 & . & . \\
\hline Slack B & $30 / 07 / 02$ & 2923 & Roadsidel & 455 & $\mathrm{CG}$ & $\mathrm{F}$ & 23 & 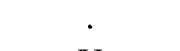 & 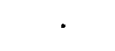 \\
\hline Slack B & $30 / 07 / 02$ & 2923 & Interior & 325 & PL & $\mathrm{F}$ & 25 & Y & \\
\hline Slack B & $30 / 07 / 02$ & 2923 & Interior & 300 & TH & 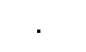 & 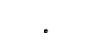 & . & - \\
\hline Slack B & $30 / 07 / 02$ & 2923 & Roadsidel & 453 & TS & $\mathrm{F}$ & 107 & $\mathrm{Y}$ & \\
\hline Slack B & $30 / 07 / 02$ & 2923 & Interior & 469 & TS & $\mathrm{F}$ & 100 & Y & within \\
\hline Slack B & $30 / 07 / 02$ & 2923 & Roadsidel & 471 & TS & $\mathrm{F}$ & 95 & . & . \\
\hline Slack B & $31 / 07 / 02$ & 2923 & Interior & 497 & PL & . & 15 & . & . \\
\hline Slack B & $31 / 07 / 02$ & 2923 & Roadside1 & 251 & TS & $\mathrm{F}$ & 92 & . & 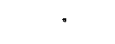 \\
\hline Slack B & $31 / 07 / 02$ & 2923 & Roadside 2 & $\mathrm{~nm}$ & TS & $\mathrm{F}$ & 91 & . & . \\
\hline Slack B & $31 / 07 / 02$ & 2923 & Roadside 2 & $\mathrm{~nm}$ & TS & . & . & . & . \\
\hline Timm & $05 / 08 / 02$ & 2346 & Roadside1 & 342 & PL & F & 25 & Y & within \\
\hline Timm & $05 / 08 / 02$ & 2346 & Interior & 342 & PL & F & 30 & Y & within \\
\hline Timm & $05 / 08 / 02$ & 2346 & Interior & 346 & PL & F & 25 & $Y$ & . \\
\hline Timm & $05 / 08 / 02$ & 2346 & Interior & 348 & PL & $\mathrm{M}$ & 20 & Y & within \\
\hline Timm & $05 / 08 / 02$ & 2346 & Roadside 2 & 460 & PL & $\mathrm{M}$ & 22 & Y & . \\
\hline Timm & $05 / 08 / 02$ & 2346 & Roadside2 & 496 & PL & $\mathrm{M}$ & 17 & . & . \\
\hline Timm & $05 / 08 / 02$ & 2346 & Roadside2 & 403 & TS & F & 83 & & \\
\hline
\end{tabular}


Appendix A cont...

\begin{tabular}{|c|c|c|c|c|c|c|c|c|c|}
\hline & & Traffic & & & & & & & \\
\hline Location & Date & Volume & Grid & Tag & Species & Sex & Mass & Recaptured & Where \\
\hline Timm & $06 / 08 / 02$ & 2346 & Interior & 324 & PL & F & 22 & $\mathrm{Y}$ & \\
\hline Timm & $06 / 08 / 02$ & 2346 & Roadside 1 & 328 & $\mathrm{PL}$ & $\mathrm{M}$ & 20 & $\mathrm{Y}$ & \\
\hline Timm & $06 / 08 / 02$ & 2346 & Roadside 1 & 418 & PL & M & 17 & $\mathrm{Y}$ & \\
\hline Timm & $06 / 08 / 02$ & 2346 & Roadside1 & 450 & PL & $\mathrm{M}$ & 17 & . & . \\
\hline Timm & $06 / 08 / 02$ & 2346 & Roadside1 & 456 & PL & $\mathrm{M}$ & 18 & $Y$ & . \\
\hline Timm & $06 / 08 / 02$ & 2346 & Roadside2 & 404 & TS & $F$ & 83 & $\mathrm{Y}$ & . \\
\hline Timm & $07 / 08 / 02$ & 2346 & Interior & 347 & PL & $\mathrm{M}$ & 13 & $Y$ & . \\
\hline Timm & $07 / 08 / 02$ & 2346 & Interior & 350 & PL & $\mathrm{M}$ & 22 & . & . \\
\hline Timm & $07 / 08 / 02$ & 2346 & Roadside2 & 422 & PL & $\mathrm{M}$ & 13 & Y & . \\
\hline Timm & 07/08/02 & 2346 & Interior & $\mathrm{nm}$ & SF & . & 25 & . & . \\
\hline Timm & $07 / 08 / 02$ & 2346 & Roadside2 & 338 & TS & $\mathrm{M}$ & 105 & . & . \\
\hline Timm & $07 / 08 / 02$ & 2346 & Roadside2 & 416 & TS & $\mathrm{M}$ & 101 & . & . \\
\hline Timm & 08/08/02 & 2346 & Interior & 405 & PL & $\mathrm{M}$ & 19 & $Y$ & across \\
\hline Timm & $08 / 08 / 02$ & 2346 & Roadside2 & 457 & PL & $\mathrm{M}$ & 17 & $\mathrm{Y}$ & 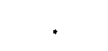 \\
\hline Timm & $08 / 08 / 02$ & 2346 & Roadside2 & 451 & TS & $\mathrm{M}$ & 97 & $\mathrm{Y}$ & within \\
\hline Timm & $08 / 08 / 02$ & 2346 & Interior & 452 & TS & $F$ & 103 & . & . \\
\hline Timm & $08 / 08 / 02$ & 2346 & Interior & 487 & TS & $\mathrm{M}$ & 104 & Y & . \\
\hline Timm & $09 / 08 / 02$ & 2346 & Roadside2 & 449 & PL & $\mathrm{F}$ & 17 & . & . \\
\hline Timm & $09 / 08 / 02$ & 2346 & Interior & $\mathrm{nm}$ & SF & . & . & & . \\
\hline Timm & $09 / 08 / 02$ & 2346 & Roadsidel & 445 & TS & $\mathrm{F}$ & 91 & $\mathrm{Y}$ & . \\
\hline Timm & $10 / 08 / 02$ & 2346 & Roadsidel & $\mathrm{nm}$ & TS & $\mathbf{M}$ & 85 & . & . \\
\hline Timm & $10 / 08 / 02$ & 2346 & Roadside2 & $\mathrm{nm}$ & TS & M & 103 & $Y$ & . \\
\hline Timm & $10 / 08 / 02$ & 2346 & Roadside2 & $\mathrm{nm}$ & TS & $\mathrm{M}$ & 103 & $Y$ & . \\
\hline Richmond02 & $14 / 08 / 02$ & 5827 & Roadside 1 & 365 & $\mathrm{CG}$ & $\mathrm{F}$ & 25 & Y & . \\
\hline Richmond02 & $14 / 08 / 02$ & 5827 & Roadside1 & 355 & PL & $\mathbf{M}$ & 25 & . & . \\
\hline Richmond02 & $14 / 08 / 02$ & 5827 & Roadsidel & 489 & PL & $\mathrm{F}$ & 23 & . & 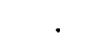 \\
\hline Richmond02 & $14 / 08 / 02$ & 5827 & Roadside 1 & $\mathrm{~nm}$ & TH & & . & . & . \\
\hline Richmond 02 & $14 / 08 / 02$ & 5827 & Roadside1 & 367 & TS & $\mathrm{M}$ & 85 & . & \\
\hline Richmond02 & $14 / 08 / 02$ & 5827 & Roadside 1 & 371 & TS & $\mathrm{F}$ & 105 & . & \\
\hline Richmond02 & $14 / 08 / 02$ & 5827 & Roadside2 & 448 & TS & $\mathrm{F}$ & 89 & Y & \\
\hline Richmond02 & $15 / 08 / 02$ & 5827 & Roadsidel & 359 & PL & M & 21 & Y & within \\
\hline Richmond 02 & $15 / 08 / 02$ & 5827 & Roadsidel & 443 & PL & M & 13 & $Y$ & within \\
\hline Richmond 02 & $15 / 08 / 02$ & 5827 & Roadside2 & 468 & PL & $F$ & 19 & $Y$ & \\
\hline Richmond02 & $15 / 08 / 02$ & 5827 & Interior & 477 & PL & $\mathrm{F}$ & 12 & $\mathrm{Y}$ & within \\
\hline Richmond02 & $15 / 08 / 02$ & 5827 & Interior & 493 & PL & $M$ & 18 & $Y$ & $\cdot$ \\
\hline Richmond02 & $15 / 08 / 02$ & 5827 & Roadside2 & 498 & PL & $\mathbf{M}$ & 22 & $Y$ & . \\
\hline Richmond02 & $15 / 08 / 02$ & 5827 & Roadside2 & $\mathrm{nm}$ & $\mathrm{TH}$ & ${ }^{\circ}$ & . & . & . \\
\hline Richmond02 & $15 / 08 / 02$ & 5827 & Roadside2 & 357 & TS & . & 95 & Y & . \\
\hline Richmond02 & $15 / 08 / 02$ & 5827 & Roadside1 & 447 & TS & M & 111 & $\mathrm{Y}$ & . \\
\hline Richmond02 & $16 / 08 / 02$ & 5827 & Interior & 435 & PL & M & 23 & . & \\
\hline Richmond02 & $16 / 08 / 02$ & 5827 & Roadside1 & 478 & PL & $\mathrm{M}$ & 15 & $\mathrm{Y}$ & within \\
\hline Richmond02 & $16 / 08 / 02$ & 5827 & Roadsidel & 440 & TS & $\mathbf{M}$ & 91 & $Y$ & \\
\hline Richmond02 & $17 / 08 / 02$ & 5827 & Roadside2 & 446 & PL & M & 25 & $Y$ & within \\
\hline Richmond02 & $18 / 08 / 02$ & 5827 & Roadside2 & 369 & PL & $\mathrm{F}$ & 20 & . & . \\
\hline Richmond02 & $19 / 08 / 02$ & 5827 & Interior & $\mathrm{nm}$ & $C G$ & 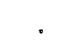 & 15 & 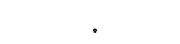 & \\
\hline Richmond02 & $19 / 08 / 02$ & 5827 & Interior & 419 & PL & M & 25 & $Y$ & within \\
\hline
\end{tabular}


Appendix A cont...

\begin{tabular}{|c|c|c|c|c|c|c|c|c|c|}
\hline & & Traffic & & & & & & & \\
\hline Location & Date & Volume & Grid & Tag & Species & Sex & Mass & Recaptured & Where \\
\hline Richmond02 & $19 / 08 / 02$ & 5827 & Interior & $\mathrm{nm}$ & PL & $\mathrm{M}$ & 22 & . & . \\
\hline Richmond02 & $19 / 08 / 02$ & 5827 & Roadsidel & $\mathrm{nm}$ & TS & $\mathrm{M}$ & 103 & . & . \\
\hline WHC & $26 / 05 / 03$ & 15433 & Roadsidel & 876 & $\mathrm{PL}$ & F & 22 & Y & within \\
\hline WHC & $26 / 05 / 03$ & 15433 & Interior & 383 & TH & $\mathrm{M}$ & 255 & Y & . \\
\hline WHC & $26 / 05 / 03$ & 15433 & Roadsidel & 900 & TH & F & 280 & $\mathrm{y}$ & . \\
\hline WHC & $26 / 05 / 03$ & 15433 & Interior & 878 & TS & $\mathbf{M}$ & 103 & $\mathrm{Y}$ & . \\
\hline WHC & $27 / 05 / 03$ & 15433 & Interior & 838 & PL & $\mathrm{F}$ & 22 & $\mathrm{Y}$ & . \\
\hline WHC & $27 / 05 / 03$ & 15433 & Interior & 377 & $\mathrm{TH}$ & $F$ & 230 & . & . \\
\hline WHC & $27 / 05 / 03$ & 15433 & Roadside2 & 821 & $\mathrm{TH}$ & $\mathrm{F}$ & 180 & $\mathrm{Y}$ & . \\
\hline WHC & $27 / 05 / 03$ & 15433 & Roadside2 & 872 & $\mathrm{TH}$ & F & 200 & Y & . \\
\hline WHC & $27 / 05 / 03$ & 15433 & Roadside2 & 820 & TS & $\mathrm{F}$ & 105 & $\mathrm{Y}$ & . \\
\hline WHC & $28 / 05 / 03$ & 15433 & Interior & 819 & TH & . & 185 & . & . \\
\hline WHC & $28 / 05 / 03$ & 15433 & Roadside2 & 828 & TH & $\mathrm{F}$ & 230 & Y & . \\
\hline WHC & $28 / 05 / 03$ & 15433 & Interior & 829 & TH & $\mathrm{M}$ & 220 & $\mathrm{Y}$ & . \\
\hline WHC & $28 / 05 / 03$ & 15433 & Roadside2 & 802 & TS & $\mathrm{M}$ & 105 & $\mathrm{Y}$ & . \\
\hline WHC & $28 / 05 / 03$ & 15433 & Roadside 1 & 803 & TS & F & 105 & $\mathrm{Y}$ & across \\
\hline WHC & $29 / 05 / 03$ & 15433 & Interior & 871 & PL & $\mathrm{M}$ & 21 & . & . \\
\hline WHC & $29 / 05 / 03$ & 15433 & Roadside2 & 870 & TH & $\mathrm{M}$ & 200 & $\mathrm{Y}$ & . \\
\hline WHC & $29 / 05 / 03$ & 15433 & Interior & 830 & TS & $\mathrm{F}$ & 110 & . & . \\
\hline WHC & $29 / 05 / 03$ & 15433 & Roadside1 & 831 & TS & $\mathrm{M}$ & 110 & . & . \\
\hline WHC & $30 / 05 / 03$ & 15433 & Roadside2 & 832 & PL & $\mathrm{M}$ & 18 & . & . \\
\hline WHC & $31 / 05 / 03$ & 15433 & Roadsidel & 851 & $\mathrm{TH}$ & F & 235 & & . \\
\hline WHC & $31 / 05 / 03$ & 15433 & Roadside2 & $\mathrm{nm}$ & TH & $\mathrm{M}$ & 215 & & . \\
\hline Richmond & $03 / 06 / 03$ & 7956 & Roadside2 & 841 & PL & $\mathrm{M}$ & 22 & Y & . \\
\hline Richmond & $03 / 06 / 03$ & 7956 & Interior & 854 & PL & $F$ & 22 & $Y$ & . \\
\hline Richmond & $03 / 06 / 03$ & 7956 & Roadside2 & 889 & TH & $\mathrm{M}$ & 230 & . & . \\
\hline Richmond & $03 / 06 / 03$ & 7956 & Roadsidel & 853 & TS & $\mathbb{F}$ & 79 & $Y$ & . \\
\hline Richmond & $04 / 06 / 03$ & 7956 & Interior & 867 & FS & M & 125 & . & . \\
\hline Richmond & $04 / 06 / 03$ & 7956 & Interior & $\mathrm{nm}$ & FS & . & . & . & . \\
\hline Richmond & $04 / 06 / 03$ & 7956 & Interior & 855 & PL & $\mathbb{F}$ & 17 & Y & . \\
\hline Richmond & $04 / 06 / 03$ & 7956 & Roadside1 & 856 & $\mathrm{TH}$ & $\mathbf{F}$ & 215 & . & . \\
\hline Richmond & $04 / 06 / 03$ & 7956 & Roadside1 & 897 & TH & $\mathbf{M}$ & 190 & $\mathrm{Y}$ & . \\
\hline Richmond & $05 / 06 / 03$ & 7956 & Roadside2 & $\mathrm{nm}$ & PL & . & . & . & . \\
\hline Richmond & $05 / 06 / 03$ & 7956 & Roadside 1 & 877 & TH & $\mathbf{M}$ & 195 & $\mathrm{Y}$ & . \\
\hline Richmond & $05 / 06 / 03$ & 7956 & Roadsidel & 880 & TH & $\mathrm{F}$ & 137 & . & . \\
\hline Richmond & $05 / 06 / 03$ & 7956 & Roadside1 & $\mathrm{nm}$ & TH & $\mathrm{M}$ & · & . & . \\
\hline Richmond & $05 / 06 / 03$ & 7956 & Roadside1 & 887 & TS & $\mathrm{M}$ & 106 & Y & \\
\hline Richmond & $06 / 06 / 03$ & 7956 & Interior & 883 & FS & $\mathrm{F}$ & 106 & $\mathrm{Y}$ & within \\
\hline Richmond & $06 / 06 / 03$ & 7956 & Interior & 894 & PL & . & 18 & . & . \\
\hline Richmond & $06 / 06 / 03$ & 7956 & Roadside1 & 866 & TS & $\mathrm{F}$ & 175 & $\mathrm{Y}$ & . \\
\hline Richmond & $07 / 06 / 03$ & 7956 & Roadside2 & 873 & $\mathrm{CG}$ & $\mathrm{F}$ & 23 & $\mathrm{Y}$ & . \\
\hline Richmond & $07 / 06 / 03$ & 7956 & Roadside2 & 521 & PL & $\mathbf{M}$ & 20 & $\mathrm{Y}$ & . \\
\hline Conroy & $08 / 06 / 03$ & 6580 & Roadside1 & $\mathrm{nm}$ & $C G$ & $\mathrm{M}$ & 16 & . & . \\
\hline Conroy & $08 / 06 / 03$ & 6580 & Interior & $\mathrm{nm}$ & $\mathrm{CG}$ & $\mathrm{F}$ & 20 & 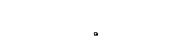 & \\
\hline Conroy & $08 / 06 / 03$ & 6580 & Roadside1 & 958 & PL & $\mathrm{F}$ & 24 & Y & \\
\hline Conroy & $08 / 06 / 03$ & 6580 & Roadside1 & 982 & $\mathrm{PL}$ & $\mathrm{M}$ & 18 & Y & \\
\hline
\end{tabular}


Appendix A cont...

\begin{tabular}{|c|c|c|c|c|c|c|c|c|c|}
\hline Location & Date & $\begin{array}{l}\text { Traffic } \\
\text { Volume }\end{array}$ & Grid & $\mathrm{Tag}$ & Species & Sex & Mass & Recaptured & Where \\
\hline Conroy & $08 / 06 / 03$ & 6580 & Interior & 989 & PL & $\mathrm{M}$ & 26 & $Y$ & \\
\hline Conroy & $08 / 06 / 03$ & 6580 & Roadsidel & 994 & PL & $F$ & 18 & . & . \\
\hline Conroy & $08 / 06 / 03$ & 6580 & Interior & $\mathrm{nm}$ & TH & F & 26 & . & . \\
\hline Conroy & $08 / 06 / 03$ & 6580 & Roadside2 & 915 & TS & F & 124 & . & . \\
\hline Conroy & $08 / 06 / 03$ & 6580 & Roadside1 & 961 & TS & $\mathbf{M}$ & 94 & Y & . \\
\hline Highway 7 & $16 / 06 / 03$ & 14700 & Interior & 721 & $\mathrm{CG}$ & $\mathrm{F}$ & 16 & . & . \\
\hline Highway 7 & $16 / 06 / 03$ & 14700 & Roadside2 & $\mathrm{nm}$ & $\mathrm{CG}$ & $\mathrm{F}$ & 24 & . & . \\
\hline Highway 7 & $16 / 06 / 03$ & 14700 & Roadside2 & 638 & $\mathrm{PL}$ & $\mathrm{M}$ & 23 & Y & . \\
\hline Highway 7 & $16 / 06 / 03$ & 14700 & Roadside2 & 949 & PL & $\mathrm{M}$ & 32 & $\mathrm{Y}$ & within \\
\hline Highway 7 & $16 / 06 / 03$ & 14700 & Interior & 950 & PL & F & 25 & $\mathrm{Y}$ & within \\
\hline Highway 7 & $16 / 06 / 03$ & 14700 & Roadside2 & 901 & TH & F & 150 & . & . \\
\hline Highway 7 & $17 / 06 / 03$ & 14700 & Roadside2 & 745 & $\mathrm{CG}$ & $\mathrm{F}$ & 16 & . & . \\
\hline Highway 7 & $17 / 06 / 03$ & 14700 & Roadside2 & 902 & $\mathrm{CG}$ & $\mathrm{M}$ & 26 & $Y$ & . \\
\hline Highway 7 & $17 / 06 / 03$ & 14700 & Roadside1 & 639 & $\mathbb{P L}$ & $\mathrm{F}$ & 26 & $Y$ & . \\
\hline Highway 7 & $18 / 06 / 03$ & 14700 & Roadside2 & 940 & $\mathrm{CG}$ & $\mathrm{M}$ & 14 & $\mathrm{Y}$ & . \\
\hline Highway 7 & $18 / 06 / 03$ & 14700 & Roadside2 & 903 & PL & $\mathrm{M}$ & 16 & . & . \\
\hline Highway 7 & $18 / 06 / 03$ & 14700 & Roadside2 & 942 & PL & $F$ & 24 & . & . \\
\hline Highway 7 & $19 / 06 / 03$ & 14700 & Interior & 746 & PL & F & 13 & . & . \\
\hline Highway 7 & $19 / 06 / 03$ & 14700 & Roadside1 & 936 & $\mathrm{PL}$ & $\mathrm{M}$ & 26 & . & . \\
\hline Highway 7 & $20 / 06 / 03$ & 14700 & Interior & 923 & $\mathrm{PL}$ & $\mathrm{M}$ & 26 & Y & . \\
\hline Highway 7 & $20 / 06 / 03$ & 14700 & Roadsidel & 927 & PL & $\mathrm{M}$ & 18 & $\mathrm{Y}$ & 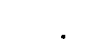 \\
\hline Highway 7 & $21 / 06 / 03$ & 14700 & Roadside2 & 943 & $\mathrm{CG}$ & $\mathrm{M}$ & 16 & . & . \\
\hline Highway 7 & $21 / 06 / 03$ & 14700 & Roadside1 & $\mathrm{nm}$ & $\mathrm{PL}$ & $\mathrm{M}$ & 14 & . & . \\
\hline Highway 7 & $21 / 06 / 03$ & 14700 & Roadside2 & $\mathrm{nm}$ & PL & $\mathbb{F}$ & 11 & . & \\
\hline Highway 7 & $21 / 06 / 03$ & 14700 & Roadside2 & $\mathrm{nm}$ & PL & F & 21 & . & \\
\hline Highway 7 & $21 / 06 / 03$ & 14700 & Interior & $\mathrm{nm}$ & PL & F & 32 & . & . \\
\hline Highway 7 & $21 / 06 / 03$ & 14700 & Interior & $\mathrm{nm}$ & $\mathrm{PL}$ & $\mathrm{M}$ & 21 & . & . \\
\hline Moodie & $24 / 06 / 03$ & 3078 & Interior & 976 & PL & $\mathrm{F}$ & 24 & $\mathrm{Y}$ & . \\
\hline Moodie & $24 / 06 / 03$ & 3078 & Interior & 998 & PL & $\mathbf{M}$ & 17 & $\mathrm{Y}$ & . \\
\hline Moodie & $24 / 06 / 03$ & 3078 & Roadside2 & $\mathrm{nm}$ & PL & . & . & . & . \\
\hline Moodie & $24 / 06 / 03$ & 3078 & Roadside2 & 904 & TH & M & 174 & $\mathrm{Y}$ & . \\
\hline Moodie & $24 / 06 / 03$ & 3078 & Roadside1 & 905 & TH & $\mathrm{F}$ & 180 & . & \\
\hline Moodie & $24 / 06 / 03$ & 3078 & Roadsidel & 906 & TS & $F$ & 68 & $Y$ & \\
\hline Moodie & $24 / 06 / 03$ & 3078 & Roadsidel & 931 & TS & F & 74 & $\mathrm{Y}$ & within \\
\hline Moodie & $24 / 06 / 03$ & 3078 & Interior & 932 & TS & $\mathrm{F}$ & 82 & $\bar{Y}$ & . \\
\hline Moodie & $24 / 06 / 03$ & 3078 & Interior & 935 & TS & $\mathbf{M}$ & 100 & $Y$ & \\
\hline Moodie & $24 / 06 / 03$ & 3078 & Roadside1 & 977 & TS & $F$ & 94 & $Y$ & within \\
\hline Moodie & $24 / 06 / 03$ & 3078 & Roadside1 & 978 & TS & M & 92 & $\mathrm{Y}$ & within \\
\hline Moodie & $24 / 06 / 03$ & 3078 & Roadside2 & 979 & TS & $\mathrm{F}$ & 70 & $Y$ & 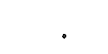 \\
\hline Moodie & $24 / 06 / 03$ & 3078 & Roadsidel & 980 & TS & $\mathrm{F}$ & 64 & $Y$ & within \\
\hline Moodie & $25 / 06 / 03$ & 3078 & Roadside2 & 919 & $\mathrm{PL}$ & $\mathbf{M}$ & 20 & $\mathrm{Y}$ & . \\
\hline Moodie & $25 / 06 / 03$ & 3078 & Roadside1 & 908 & TS & $\mathrm{M}$ & 64 & $\mathrm{Y}$ & within \\
\hline Moodie & $25 / 06 / 03$ & 3078 & Roadside1 & 909 & $\mathrm{TS}$ & $\mathrm{F}$ & 120 & $Y$ & within \\
\hline Moodie & $25 / 06 / 03$ & 3078 & Roadside1 & 920 & TS & $\mathrm{F}$ & 145 & $Y$ & within \\
\hline Moodie & $25 / 06 / 03$ & 3078 & Interior & 981 & TS & F & 130 & . & . \\
\hline Moodie & $25 / 06 / 03$ & 3078 & Roadside2 & 994 & TS & $F$ & 68 & & \\
\hline
\end{tabular}


Appendix A cont...

\begin{tabular}{lccccccccc}
\hline Location & Date & Volume & Grid & Tag & Species & Sex & Mass & Recaptured & Where \\
\hline Moodie & $26 / 06 / 03$ & 3078 & Roadside2 & 922 & PL & F & 24 & Y &. \\
Moodie & $26 / 06 / 03$ & 3078 & Roadside2 & 996 & PL & M & 22 &. &. \\
Moodie & $26 / 06 / 03$ & 3078 & Interior & 934 & TS & M & 80 & Y &. \\
Moodie & $26 / 06 / 03$ & 3078 & Interior & 990 & TS & F & 102 &. &. \\
Moodie & $27 / 06 / 03$ & 3078 & Interior & 986 & PL & F & 19 & Y &. \\
Moodie & $27 / 06 / 03$ & 3078 & Interior & 984 & TS & M & 96 & Y &. \\
Moodie & $27 / 06 / 03$ & 3078 & Interior & 995 & TS & F & 68 &. &. \\
Moodie & $27 / 06 / 03$ & 3078 & Interior & 997 & TS & M & 100 &. &. \\
Moodie & $27 / 06 / 03$ & 3078 & Roadside2 & 999 & TS & F & 62 & Y &. \\
Moodie & $28 / 06 / 03$ & 3078 & Roadside2 & nm & PL & F & 25 &. &. \\
Moodie & $28 / 06 / 03$ & 3078 & Roadside1 & nm & TS & F & 100 &. &. \\
Moodie & $28 / 06 / 03$ & 3078 & Roadside1 & nm & TS & F & 74 &. &. \\
Moodie & $28 / 06 / 03$ & 3078 & Roadside1 & nm & TS & F & 120 &. &. \\
Moodie & $28 / 06 / 03$ & 3078 & Interior & nm & TS & F & 120 & Y &. \\
Conroy & $07 / 08 / 03$ & 6580 & Interior & nm & FS & M & 100 &. &. \\
Conroy & $07 / 08 / 03$ & 6580 & Roadside1 & 980 & PL & F & 38 & Y &. \\
Conroy & $07 / 08 / 03$ & 6580 & Interior & 991 & PL & M & 28 & Y &. \\
Conroy & $07 / 08 / 03$ & 6580 & Roadside1 & 995 & PL & F & 26 & Y &. \\
Conroy & $07 / 08 / 03$ & 6580 & Roadside2 & 914 & TS & M & 300 & Y &. \\
Conroy & $08 / 08 / 03$ & 6580 & Interior & 979 & PL & F & 24 & Y &. \\
Conroy & $08 / 08 / 03$ & 6580 & Roadside1 & 988 & PL & M & 16 &. &. \\
\hline
\end{tabular}


Appendix B. Data for trapping protocol two. Locations are names of sites used in 2002 and 2003. Traffic volume is average annual daily traffic volumes. Individuals received a unique tag number. Animals were translocated either gcross roads (AR) or within the patch (WP). Animals that were recaptured within the 6 aight trapping session for each site were recorded as returming. Ts: Tomias scurius, $\mathbb{P L}$ : Perowyscus leucopus.

\begin{tabular}{|c|c|c|c|c|c|c|c|c|c|}
\hline Location & $\begin{array}{c}\text { Date } \\
\text { Translocated }\end{array}$ & $\begin{array}{c}\text { Date } \\
\text { Recaptured }\end{array}$ & $\begin{array}{l}\text { Traffic } \\
\text { Volume }\end{array}$ & Tag & Species & Sex & Mass & Translocated & Return \\
\hline WHC 2002 & $09 / 05 / 02$ & . & 13423 & 1120 & TS & $\mathrm{M}$ & 100 & $A \mathbb{R}$ & $\mathrm{N}$ \\
\hline WHC 2002 & $09 / 05 / 02$ & . & 13423 & 1140 & $\mathrm{PL}$ & $\mathrm{M}$ & 22 & $\mathrm{AR}$ & $\mathrm{N}$ \\
\hline WHC 2002 & $10 / 05 / 02$ & $11 / 05 / 02$ & 13423 & 1101 & TS & F & 86 & AR & $\mathrm{Y}$ \\
\hline WHC 2002 & $11 / 05 / 02$ & $12 / 05 / 02$ & 13423 & 1102 & TS & F & 90 & WP & $\mathrm{Y}$ \\
\hline Davidson & $19 / 05 / 02$ & . & 1670 & 1187 & TS & F & 90 & AR & $\mathrm{N}$ \\
\hline Davidson & $22 / 05 / 02$ & $24 / 05 / 02$ & 1670 & 1006 & $\mathrm{TS}$ & $\mathrm{M}$ & 100 & WP & Y \\
\hline Davidson & $24 / 05 / 02$ & $25 / 05 / 02$ & 1670 & 1161 & TS & $\mathrm{M}$ & 98 & AR & $Y$ \\
\hline Mer Bleu & $01 / 06 / 02$ & . & 47 & 1162 & TS & F & 130 & $\mathrm{AR}$ & $\mathrm{N}$ \\
\hline Mer Bleu & $03 / 06 / 02$ & . & 47 & 1137 & TS & $\mathrm{M}$ & 112 & AR & $\mathrm{N}$ \\
\hline Mer Bleu & $04 / 06 / 02$ & . & 47 & 1163 & TS & $\mathbf{M}$ & 90 & WP & $\mathrm{N}$ \\
\hline Mer Bleu & $04 / 06 / 02$ & $05 / 06 / 02$ & 47 & 1108 & TS & $\mathrm{F}$ & 100 & WP & Y \\
\hline Moodie 2002 & $14 / 06 / 02$ & $15 / 06 / 02$ & 3025 & 1172 & $\mathrm{PL}$ & $\mathrm{M}$ & 28 & AR & $\mathrm{Y}$ \\
\hline Moodie 2002 & $14 / 06 / 02$ & . & 3025 & 1190 & TS & $\mathrm{M}$ & 108 & WP & $\mathrm{N}$ \\
\hline Slack & $22 / 06 / 02$ & . & 2677 & 1192 & TS & $\mathrm{F}$ & 100 & AR & $\mathrm{N}$ \\
\hline Slack & $22 / 06 / 02$ & $23 / 06 / 02$ & 2677 & 1168 & TS & M & 104 & SS & $Y$ \\
\hline Slack & $24 / 06 / 02$ & $25 / 06 / 02$ & 2677 & 1111 & $\mathrm{TS}$ & $\mathrm{F}$ & 110 & WP & $Y$ \\
\hline Slack & $24 / 06 / 02$ & $24 / 06 / 02$ & 2677 & 1152 & TS & $\mathbf{M}$ & 111 & WP & $\mathrm{Y}$ \\
\hline Slack & $25 / 06 / 02$ & $26 / 06 / 02$ & 2677 & 1194 & TS & M & 92 & WP & $Y$ \\
\hline Slack & $27 / 06 / 02$ & $27 / 06 / 02$ & 2677 & 1151 & TS & $\mathrm{M}$ & 110 & $\mathrm{AR}$ & Y \\
\hline Lester 2002 & $15 / 07 / 02$ & $16 / 07 / 02$ & 7760 & 273 & TS & $\mathrm{M}$ & 100 & AR & Y \\
\hline Lester 2002 & $15 / 07 / 02$ & $17 / 07 / 02$ & 7760 & 274 & TS & $\mathrm{F}$ & 94 & WP & $Y$ \\
\hline Lester 2002 & $15 / 07 / 02$ & $16 / 07 / 02$ & 7760 & 300 & PL & $\mathbb{F}$ & 20 & WP & Y \\
\hline Lester 2002 & $17 / 07 / 02$ & $19 / 07 / 02$ & 7760 & 299 & PL & $\mathrm{M}$ & 22 & AR & $Y$ \\
\hline Lester 2002 & $19 / 07 / 02$ & . & 7760 & 203 & PL & M & 20 & $\mathrm{AR}$ & $\mathrm{N}$ \\
\hline Lester 2002 & $19 / 07 / 02$ & $19 / 07 / 02$ & 7760 & 272 & PL & $\mathrm{M}$ & 16 & WP & $\mathrm{Y}$ \\
\hline Slack B & $29 / 07 / 02$ & $31 / 07 / 02$ & 2923 & 210 & PL & $\mathrm{F}$ & 23 & WP & Y \\
\hline Slack B & $31 / 07 / 02$ & & 2923 & 202 & TS & F & 87 & $\mathrm{AR}$ & $\mathrm{N}$ \\
\hline Slack B & $31 / 07 / 02$ & . & 2923 & 257 & PL & $\mathrm{M}$ & 25 & WP & $\mathrm{N}$ \\
\hline Timm & $05 / 08 / 02$ & $06 / 08 / 02$ & 2346 & 454 & PL & M & 17 & $\mathrm{AR}$ & Y \\
\hline Timm & $06 / 08 / 02$ & 07/08/02 & 2346 & 405 & PL & M & 19 & $\mathrm{AR}$ & Y \\
\hline Timm & $06 / 08 / 02$ & $07 / 08 / 02$ & 2346 & 417 & PL & $\mathrm{M}$ & 20 & AR & $\mathrm{Y}$ \\
\hline Timm & 07/08/02 & 08/08/02 & 2346 & 406 & PL & $\mathrm{F}$ & 15 & WP & $\mathrm{Y}$ \\
\hline Timm & $08 / 08 / 02$ & 09/08/02 & 2346 & 457 & PL & M & 18 & WP & Y \\
\hline Richmond & $15 / 08 / 02$ & $16 / 08 / 02$ & 5827 & 419 & PL & $\mathrm{M}$ & 25 & WP & $\mathrm{Y}$ \\
\hline Richmond & $17 / 08 / 02$ & & 5827 & 476 & TS & $\mathrm{F}$ & 99 & $\mathrm{AR}$ & $\mathrm{N}$ \\
\hline Richmond & $17 / 08 / 02$ & $18 / 08 / 02$ & 5827 & 448 & TS & $F$ & 85 & WP & Y \\
\hline Richmond & $18 / 08 / 02$ & $19 / 08 / 02$ & 5827 & 486 & TS & $\mathbf{M}$ & 100 & AR & Y \\
\hline Moodie & $03 / 06 / 03$ & $04 / 06 / 03$ & 6519 & 888 & PL & $F$ & 20 & AR & Y \\
\hline Moodie & $03 / 06 / 03$ & $04 / 06 / 03$ & 6519 & 898 & TS & $F$ & 100 & AR & Y \\
\hline Moodie & $03 / 06 / 03$ & $04 / 06 / 03$ & 6519 & 899 & PL & M & 26 & AR & $\mathrm{Y}$ \\
\hline Moodie & $04 / 06 / 03$ & $05 / 06 / 03$ & 6519 & 889 & $\mathrm{PL}$ & $\mathrm{F}$ & 18 & SS & $Y$ \\
\hline
\end{tabular}


Appendix B cont...

\begin{tabular}{|c|c|c|c|c|c|c|c|c|c|}
\hline Location & $\begin{array}{c}\text { Date } \\
\text { Translocated }\end{array}$ & $\begin{array}{c}\text { Date } \\
\text { Recaptured }\end{array}$ & $\begin{array}{l}\text { Traffic } \\
\text { Volume }\end{array}$ & $\mathrm{Tag}$ & Species & Sex & Mass & Translocated & Return \\
\hline Moodie & $04 / 06 / 03$ & $\cdot$ & 6519 & 868 & $\mathrm{BL}$ & $\mathrm{F}$ & 10 & WP & $\mathrm{N}$ \\
\hline Moodie & $08 / 06 / 03$ & . & 6519 & 865 & PL & $F$ & 47 & WP & $N$ \\
\hline Moodie & $09 / 06 / 03$ & $12 / 06 / 03$ & 780 & 647 & PL & M & 24 & WP & $\mathrm{Y}$ \\
\hline Moodie & $10 / 06 / 03$ & $11 / 06 / 03$ & 780 & 632 & TS & $\mathrm{M}$ & 82 & $\mathrm{AR}$ & $Y$ \\
\hline Moodie & $10 / 06 / 03$ & $11 / 06 / 03$ & 780 & 635 & $\mathrm{TS}$ & $\mathrm{M}$ & 85 & $\mathrm{AR}$ & $Y$ \\
\hline Moodie & $10 / 06 / 03$ & $12 / 06 / 03$ & 780 & 860 & PL & $\mathbf{M}$ & 23 & WP & $Y$ \\
\hline Moodie & $11 / 06 / 03$ & . & 780 & 863 & $\mathrm{PL}$ & $\mathrm{M}$ & 23 & WP & $\mathrm{N}$ \\
\hline Moodie & $11 / 06 / 03$ & $11 / 06 / 03$ & 780 & 636 & TS & $\mathrm{M}$ & 90 & WP & $\mathrm{Y}$ \\
\hline Moodie & $11 / 06 / 03$ & $12 / 06 / 03$ & 780 & 637 & $\mathrm{TS}$ & $\mathbf{M}$ & 87 & WP & $\mathrm{Y}$ \\
\hline Moodie & $12 / 06 / 03$ & . & 780 & 861 & $\mathrm{TS}$ & $\mathrm{M}$ & 140 & $\mathrm{AR}$ & $\mathrm{N}$ \\
\hline Moodie & $12 / 06 / 03$ & . & 780 & 646 & PL & $\mathrm{M}$ & 22 & WP & $N$ \\
\hline Moodie & $12 / 06 / 03$ & $13 / 06 / 03$ & 780 & 862 & TS & $\mathrm{M}$ & 110 & WP & $\mathrm{Y}$ \\
\hline Moodie & $13 / 06 / 03$ & $14 / 06 / 03$ & 780 & 638 & TS & $\mathbf{M}$ & 90 & WP & $\mathrm{Y}$ \\
\hline WHC & $01 / 07 / 03$ & . & 15433 & 2988 & TS & F & 104 & AR & $\mathrm{N}$ \\
\hline WHC & $01 / 07 / 03$ & . & 15433 & 2991 & PL & F & 20 & $\mathrm{AR}$ & $N$ \\
\hline WHC & $01 / 07 / 03$ & . & 15433 & 2992 & PL & $\mathrm{M}$ & 24 & $\mathrm{AR}$ & $\mathrm{N}$ \\
\hline WHC & $01 / 07 / 03$ & . & 15433 & 2982 & $\mathrm{TS}$ & $\mathrm{F}$ & 68 & WP & $\mathrm{N}$ \\
\hline WHC & $02 / 07 / 03$ & $03 / 07 / 03$ & 15433 & 2652 & $\mathrm{TS}$ & $\mathrm{M}$ & 66 & WP & $Y$ \\
\hline Highway 7 & $15 / 07 / 03$ & . & 13500 & 666 & PL & $\mathbf{M}$ & 24 & $\mathrm{AR}$ & $\mathrm{N}$ \\
\hline Highway 7 & $15 / 07 / 03$ & $16 / 07 / 03$ & 13500 & 668 & $\mathrm{PL}$ & $\mathrm{F}$ & 24 & $\mathrm{AR}$ & $Y$ \\
\hline Moores & $15 / 07 / 03$ & $17 / 07 / 03$ & 14700 & 665 & PL & $\mathrm{F}$ & 27 & $\mathrm{AR}$ & $\mathrm{Y}$ \\
\hline Highway 7 & $15 / 07 / 03$ & $19 / 07 / 03$ & 13500 & 667 & PL & $\mathrm{M}$ & 26 & WP & $\mathrm{Y}$ \\
\hline Moores & $15 / 07 / 03$ & $15 / 07 / 03$ & 14700 & 662 & PL & $\mathrm{F}$ & 23 & WP & Y \\
\hline Highway 7 & $16 / 07 / 03$ & & 13500 & 659 & PL & $\mathrm{F}$ & 31 & $\mathrm{AR}$ & $N$ \\
\hline Moores & $16 / 07 / 03$ & $17 / 07 / 03$ & 14700 & 239 & PL & $F$ & 26 & $\mathrm{AR}$ & $Y$ \\
\hline Moores & $16 / 07 / 03$ & $18 / 07 / 03$ & 14700 & 657 & PL & M & 22 & $\mathrm{AR}$ & $\mathrm{Y}$ \\
\hline Moores & $16 / 7 / 03$ & $\cdot$ & 14700 & 1436 & PL & $\mathrm{F}$ & 24 & WP & $N$ \\
\hline Highway 7 & $16 / 7 / 03$ & $17 / 07 / 03$ & 13500 & 669 & $\mathrm{PL}$ & $\mathrm{F}$ & 25 & WP & Y \\
\hline Highway 7 & $16 / 7 / 03$ & $17 / 07 / 03$ & 13500 & 1416 & TS & $\mathrm{F}$ & 105 & WP & $\mathrm{Y}$ \\
\hline Moores & $16 / 07 / 03$ & $19 / 07 / 03$ & 14700 & 664 & PL & $\mathrm{M}$ & 23 & WP & $Y$ \\
\hline Moores & $16 / 7 / 03$ & $17 / 07 / 03$ & 14700 & 1433 & $\mathrm{PL}$ & $\mathbf{F}$ & 29 & WP & $Y$ \\
\hline Moores & $16 / 7 / 03$ & $19 / 07 / 03$ & 14700 & 1442 & PL & $\mathbf{M}$ & 10 & WP & $\mathrm{Y}$ \\
\hline Highway 7 & $17 / 07 / 03$ & . & 13500 & 660 & $\mathrm{TS}$ & $F$ & 95 & $\mathrm{AR}$ & $\mathrm{N}$ \\
\hline Highway 7 & $17 / 7 / 03$ & . & 13500 & 1415 & $\mathrm{TS}$ & $F$ & 104 & $\mathrm{AR}$ & $\mathrm{N}$ \\
\hline Highway 7 & $17 / 7 / 03$ & . & 13500 & 1433 & TS & & 76 & AR & $\mathrm{N}$ \\
\hline Highway 7 & $17 / 07 / 03$ & $18 / 07 / 03$ & 13500 & 663 & TS & $\mathrm{M}$ & 90 & $\mathrm{AR}$ & $\mathrm{Y}$ \\
\hline Highway 7 & $17 / 7 / 03$ & $18 / 07 / 03$ & 13500 & 1429 & TS & M & 81 & AR & $Y$ \\
\hline Moores & $17 / 7 / 03$ & $18 / 07 / 03$ & 14700 & 654 & $P L$ & M & 15 & WP & $Y$ \\
\hline Highway 7 & $18 / 07 / 03$ & $\cdot$ & 13500 & 971 & $\mathrm{PL}$ & $\mathrm{F}$ & 28 & AR & $\mathrm{N}$ \\
\hline Highway 7 & $18 / 07 / 03$ & 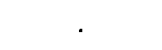 & 13500 & 2951 & PL & $\mathrm{F}$ & 31 & $\mathrm{AR}$ & $N$ \\
\hline Moores & $18 / 07 / 03$ & . & 14700 & 1431 & $\mathrm{TS}$ & $\mathrm{M}$ & 110 & $\mathrm{AR}$ & $\mathrm{N}$ \\
\hline Moores & $18 / 07 / 03$ & $19 / 07 / 03$ & 14700 & 653 & PL & $M$ & 20 & $\mathrm{AR}$ & $Y$ \\
\hline Moores & $18 / 07 / 03$ & $19 / 07 / 03$ & 14700 & 1432 & PL & F & 28 & AR & $Y$ \\
\hline Moores & $18 / 07 / 03$ & 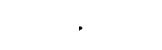 & 14700 & 652 & PL & $\mathrm{F}$ & 27 & WP & $\mathrm{N}$ \\
\hline Highway 7 & $18 / 07 / 03$ & $19 / 07 / 03$ & 13500 & 2993 & TS & $\mathrm{M}$ & 95 & WP & $\mathrm{Y}$ \\
\hline Moores & $18 / 07 / 03$ & $19 / 07 / 03$ & 14700 & 658 & PL & $\mathrm{M}$ & 30 & WP & $\mathrm{Y}$ \\
\hline
\end{tabular}


Appendix B cont...

Date Date Traffic

\begin{tabular}{|c|c|c|c|c|c|c|c|c|c|}
\hline Location & Translocated & Recaptured & Volume & Tag & Species & Sex & Mass & Translocated & Return \\
\hline Moores & $18 / 07 / 03$ & $19 / 07 / 03$ & 14700 & 661 & PL & F & 19 & WP & $\mathrm{Y}$ \\
\hline Lester & $29 / 07 / 03$ & . & 8254 & 3985 & PL & $\mathrm{M}$ & 18 & WP & $\mathrm{N}$ \\
\hline Lester & $29 / 07 / 03$ & $30 / 07 / 03$ & 8254 & 2969 & PL & $\mathrm{M}$ & 17 & WP & Y \\
\hline Lester & $31 / 07 / 03$ & & 8254 & 3997 & PL & $\mathrm{F}$ & 18 & $\mathrm{WP}$ & $\mathrm{N}$ \\
\hline
\end{tabular}


Appendix C. Data for trapping protocol three. Traffic volume is the sum of the AADT for each of the roads that are between the home and destination patches. Edge-to-edge distance was measured between home and destination sites using a GIS based application or field marking tape. Individuals were marked with a unique tag. Animals that were recaptured within the 6 night trappng session for each site were recorded as returned. PL: Peronyscis leucopus, TS: Tomias striatus.

\begin{tabular}{|c|c|c|c|c|c|c|}
\hline Location & $\begin{array}{c}\text { Road } \\
\text { Number }\end{array}$ & $\begin{array}{c}\text { Traffic } \\
\text { Volume } \\
\end{array}$ & Distance (m) & Tag & Return & Species \\
\hline 2nd Line $n$. of Phelan Rd & 0 & 0 & 10.4 & 2501 & $\mathbb{N}$ & TS \\
\hline 2nd Line $n$. of Phelan Rd & 0 & 0 & 10.4 & 2168 & Y & $\mathrm{PL}$ \\
\hline 2nd Line $\mathrm{n}$. of Phelan Rd & 2 & 0 & 10.4 & 2169 & Y & TS \\
\hline 2nd Line $n$. of Phelan Rd & 2 & 0 & 10.4 & 2172 & Y & PL \\
\hline 3rd Line s. of Roger Stevens Rd & 0 & 0 & 82 & 2174 & Y & PL \\
\hline 3rd Line s. of Roger Stevens Rd & 0 & 0 & 82 & 2175 & Y & TS \\
\hline 3rd Line s. of Roger Stevens Rd & 0 & 0 & 82 & 2180 & Y & TS \\
\hline 3rd Line s. of Roger Stevens Rd & 0 & 0 & 82 & 2503 & Y & PL \\
\hline 3rd Line s. of Roger Stevens Rd & 1 & 0 & 82 & 2194 & N & TS \\
\hline 3rd Line s. of Roger Stevens Rd & 1 & 0 & 82 & 2516 & $\mathrm{~N}$ & $P L$ \\
\hline 3rd Line s. of Roger Stevens Rd & 1 & 0 & 82 & 2504 & $\mathrm{~N}$ & TS \\
\hline 3rd Line s. of Roger Stevens Rd & 1 & 0 & 82 & 132 & $N$ & $P L$ \\
\hline 3rd Line s. of Roger Stevens Rd & 2 & 0 & 82 & 2195 & $\mathrm{~N}$ & $\mathrm{PL}$ \\
\hline 4th Line s. of Carsonby Rd & 2 & 0 & 82 & 2507 & $N$ & TS \\
\hline Blanchfield Rd & 1 & 0 & 90.5 & 2550 & $N$ & TS \\
\hline Blanchfield Rd & 3 & 0 & 90.5 & 2558 & $\mathbb{N}$ & TS \\
\hline McCordick Road & 2 & 0 & 94.9 & 166 & $N$ & PL \\
\hline McCordick Road & 2 & 0 & 94.9 & 167 & $N$ & TS \\
\hline McCordick Road & 2 & 0 & 94.9 & 178 & $N$ & $P L$ \\
\hline McCordick Road & 2 & 0 & 94.9 & 187 & N & TS \\
\hline McCordick Road & 2 & 0 & 94.9 & 194 & N & PL \\
\hline 2nd Line s. of Hwy 72 & 1 & 0 & 112.4 & 206 & $Y$ & TS \\
\hline 2nd Line s. of Hwy 72 & 1 & 0 & 112.4 & 234 & Y & PL \\
\hline 2nd Line s. of Hwy 72 & 2 & 0 & 112.4 & 209 & N & PL \\
\hline 2nd Line s. of Hwy 72 & 2 & 0 & 112.4 & 219 & N & PL \\
\hline Airport & 0 & 0 & 126.8 & 2147 & Y & $\mathrm{PL}$ \\
\hline Airport & 0 & 0 & 126.8 & 2156 & $Y$ & TS \\
\hline Airport & 1 & 0 & 126.8 & 2148 & $N$ & TS \\
\hline Airport & 1 & 0 & 126.8 & 2161 & $N$ & TS \\
\hline John Shaw Road & 1 & 0 & 128.5 & 2578 & $N$ & TS \\
\hline John Shaw Road & 1 & 0 & 128.5 & 2579 & $N$ & PL \\
\hline John Shaw Road & 1 & 0 & 128.5 & 2590 & $N$ & TS \\
\hline John Shaw Road & 1 & 0 & 128.5 & 2594 & $\mathrm{~N}$ & $\mathrm{PL}$ \\
\hline John Shaw Road & 1 & 0 & 128.5 & 2597 & $N$ & PL \\
\hline Spratt 2 & 0 & 0 & 135.8 & 2160 & $N$ & $\mathrm{PL}$ \\
\hline Spratt 2 & 0 & 0 & 135.8 & 2140 & $Y$ & $\mathrm{PL}$ \\
\hline Blanchfield Rd & 1 & 0 & 175.6 & 2534 & $N$ & TS \\
\hline Blanchfield Rd & 1 & 0 & 175.6 & 2551 & $\mathbf{N}$ & TS \\
\hline Blanchfield Rd & 1 & 0 & 175.6 & 2559 & $N$ & $\mathrm{PL}$ \\
\hline Blanchfield Rd & 1 & 0 & 175.6 & 2560 & $N$ & TS \\
\hline
\end{tabular}


Appendix C cont...

\begin{tabular}{|c|c|c|c|c|c|c|}
\hline Location & $\begin{array}{c}\text { Road } \\
\text { Number }\end{array}$ & $\begin{array}{c}\text { Traffic } \\
\text { Volume }\end{array}$ & Distance $(m)$ & Tag & Return & Species \\
\hline Airport & 1 & 0 & 193.4 & 2154 & $N$ & TS \\
\hline Airport & 1 & 0 & 193.4 & 2159 & $N$ & PL \\
\hline Airport & 1 & 0 & 193.4 & 2164 & $N$ & TS \\
\hline 3rd Line s. of Carsonby Rd & 0 & 0 & 264 & 103 & $Y$ & $\mathrm{PL}$ \\
\hline 3rd Line s. of Carsonby Rd & 0 & 0 & 264 & 118 & Y & PL \\
\hline McCordick Road & 1 & 0 & 294.7 & 175 & $\mathbb{N}$ & PL \\
\hline McCordick Road & 1 & 0 & 294.7 & 176 & $\mathbb{N}$ & TS \\
\hline McCordick Road & 2 & 0 & 294.7 & 193 & $\mathbb{N}$ & PL \\
\hline 2nd Line s. of Roger Stevens & 1 & 0 & 338.3 & 203 & Y & PL \\
\hline 2nd Line s. of Roger Stevens & 2 & 0 & 338.3 & 231 & $\mathbb{N}$ & PL \\
\hline 2nd Line s. of Roger Stevens & 2 & 0 & 338.3 & 237 & $N$ & PL \\
\hline 3rd Line s. of Bankfield Rd & 0 & 0 & 347 & 70 & $Y$ & TS \\
\hline 3rd Line s. of Bankfield Rd & 1 & 0 & 347 & 71 & $N$ & $\mathrm{PL}$ \\
\hline 3rd Line s. of Bankfield Rd & 1 & 0 & 347 & 112 & $N$ & $\mathrm{PL}$ \\
\hline Jake Street, Osgoode & 0 & 0 & 455.5 & 262 & $N$ & $\mathrm{PL}$ \\
\hline Jake Street, Osgoode & 0 & 0 & 455.5 & 269 & $N$ & TS \\
\hline Jake Street, Osgoode & 1 & 0 & 455.5 & 246 & $N$ & PL \\
\hline Jake Street, Osgoode & 1 & 0 & 455.5 & 270 & $N$ & TS \\
\hline Jake Street, Osgoode & 1 & 0 & 455.5 & 290 & $\mathrm{~N}$ & PL \\
\hline Mohr's Road & 0 & 0 & 488.4 & 2577 & $N$ & PL \\
\hline Mohr's Road & 0 & 0 & 488.4 & 2586 & $N$ & TS \\
\hline Mohr's Road & 0 & 0 & 488.4 & 84 & $N$ & TS \\
\hline Mohr's Road & 1 & 0 & 488.4 & 50 & $Y$ & $\mathrm{PL}$ \\
\hline Mohr's Road & 0 & 0 & 533.3 & 94 & $N$ & $P L$ \\
\hline Mohr's Road & 1 & 0 & 533.3 & 2576 & $\mathbb{N}$ & PL \\
\hline Mohr's Road & 1 & 0 & 533.3 & 2585 & $N$ & TS \\
\hline Mohr's Road & 1 & 0 & 533.3 & 2599 & N & PL \\
\hline Mohr's Road & 1 & 0 & 533.3 & 2587 & Y & TS \\
\hline 2nd Line at Dalmeny Road & 0 & 0 & 655.3 & 251 & N & PL \\
\hline 2nd Line at Dalmeny Road & 0 & 0 & 655.3 & 278 & N & TS \\
\hline 2nd Line at Dalmeny Road & 0 & 0 & 655.3 & 291 & N & $\mathrm{PL}$ \\
\hline 2nd Line at Dalmeny Road & 0 & 0 & 655.3 & 256 & Y & PL \\
\hline Jake Street, Osgoode & 1 & 0 & 663.3 & 260 & $\mathbb{N}$ & $\mathrm{PL}$ \\
\hline Jake Street, Osgoode & 1 & 0 & 663.3 & 265 & $\mathbb{N}$ & TS \\
\hline Jake Street, Osgoode & 1 & 0 & 663.3 & 255 & $\mathbb{N}$ & $\mathrm{PL}$ \\
\hline Jake Street, Osgoode & 1 & 0 & 663.3 & 274 & $\mathbb{N}$ & TS \\
\hline Jake Street, Osgoode & 1 & 0 & 663.3 & 288 & $\mathbb{N}$ & PL \\
\hline Jake Street, Osgoode & 2 & 0 & 880.3 & 2583 & $N$ & TS \\
\hline John Shaw Road & 2 & 0 & 880.3 & 2591 & N & $\mathrm{PL}$ \\
\hline John Shaw Road & 2 & 0 & 880.3 & 91 & $\mathbb{N}$ & TS \\
\hline John Shaw Road & 1 & 0 & 880.6 & 2580 & $N$ & $\mathrm{PL}$ \\
\hline John Shaw Road & 2 & 0 & 897.4 & 169 & $\mathbb{N}$ & TS \\
\hline McCordick Road & 2 & 0 & 897.4 & 173 & $\mathbb{N}$ & $\mathrm{PL}$ \\
\hline McCordick Road & 2 & 0 & 897.4 & 184 & $\mathbb{N}$ & PL \\
\hline McCordick Road & 2 & 0 & 897.4 & 195 & $N$ & $\mathrm{PL}$ \\
\hline McCordick Road & 1 & 0 & 953.6 & 277 & $N$ & $\mathrm{PL}$ \\
\hline
\end{tabular}


Appendix $\mathrm{C}$ cont...

\begin{tabular}{|c|c|c|c|c|c|c|}
\hline Location & $\begin{array}{c}\text { Road } \\
\text { Number }\end{array}$ & $\begin{array}{l}\text { Traffic } \\
\text { Volume }\end{array}$ & Distance (m) & Tag & Return & Species \\
\hline 2nd Line at Dalmeny Road & 1 & 0 & 953.6 & 281 & $N$ & TS \\
\hline 2nd Line at Dalmeny Road & 1 & 0 & 1025 & 2564 & $\mathbb{N}$ & PL \\
\hline Limebank at Highschool & 1 & 0 & 1025 & 2570 & N & PL \\
\hline Limebank at Highschool & 1 & 0 & 1369 & 2565 & $\mathbb{N}$ & PL \\
\hline Limebank at Highschool & 1 & 0 & 1369 & 2571 & $\mathbb{N}$ & PL \\
\hline Limebank at Highschool & 0 & 10 & 248.6 & 136 & $N$ & PL \\
\hline 4th Line $s$, of Carsonby Rd & 0 & 10 & 248.6 & 158 & $\mathbb{N}$ & $\mathrm{PL}$ \\
\hline 4th Line s. of Carsonby Rd & 0 & 10 & 248.6 & 128 & $N$ & PL \\
\hline 4th Line s. of Carsonby Rd & 0 & 10 & 248.6 & 146 & $N$ & $\mathrm{PL}$ \\
\hline 4th Line s. of Carsonby Rd & 0 & 10 & 248.6 & 140 & $N$ & $P L$ \\
\hline 4th Line s. of Carsonby Rd & 1 & 10 & 781.6 & 160 & $N$ & $P L$ \\
\hline 3rd Line n. of Hwy 72 & 1 & 10 & 781.6 & 190 & $N$ & PL \\
\hline 3rd Line $n$. of Hwy 72 & 1 & 32 & 10.4 & 192 & $N$ & TS \\
\hline 3rd Line $n$. of Hwy 72 & 1 & 32 & 10.4 & 198 & $N$ & PL \\
\hline 3rd Line n. of Hwy 72 & 2 & 32 & 10.4 & 156 & Y & $P L$ \\
\hline 3rd Line n. of Hwy 72 & 2 & 32 & 10.4 & 180 & $Y$ & $\mathrm{PL}$ \\
\hline 3rd Line $n$. of Hwy 72 & 1 & 32 & 958.5 & 65 & $\mathbb{N}$ & TS \\
\hline 3rd Line s. of Carsonby Rd & 1 & 32 & 958.5 & 67 & N & $\mathrm{PL}$ \\
\hline 3rd Line s. of Carsonby Rd & 1 & 32 & 958.5 & 106 & $N$ & PL \\
\hline 3rd Line s, of Carsonby Rd & 1 & 33 & 649.8 & 2533 & $N$ & TS \\
\hline Cabin Rd & 1 & 33 & 649.8 & 2546 & $\mathrm{~N}$ & PL \\
\hline Cabin Rd & 1 & 33 & 649.8 & 2547 & $N$ & TS \\
\hline Cabin Rd & 1 & 33 & 649.8 & 2553 & $N$ & TS \\
\hline Cabin $\mathrm{Rd}$ & 1 & 33 & 649.8 & 2520 & $Y$ & $\mathrm{PL}$ \\
\hline Cabin Rd & 1 & 33 & 649.8 & 2531 & $Y$ & PL \\
\hline Cabin Rd & 3 & 33 & 649.8 & 2525 & $\mathbb{N}$ & TS \\
\hline Cabin Rd & 4 & 33 & 649.8 & 2529 & $N$ & TS \\
\hline Cabin Rd & 1 & 50 & 302.5 & 233 & $N$ & $\mathrm{PL}$ \\
\hline 2nd Line s. of Roger Stevens & 1 & 50 & 302.5 & 240 & $\mathbb{N}$ & $\mathrm{PL}$ \\
\hline 2nd Line s. of Roger Stevens & 2 & 50 & 302.5 & 201 & $N$ & PL \\
\hline 2nd Line s. of Roger Stevens & 2 & 50 & 302.5 & 223 & $N$ & $\mathrm{PL}$ \\
\hline 2nd Line s. of Roger Stevens & 0 & 50 & 478.6 & 2566 & $N$ & TS \\
\hline Spratt 1 & 1 & 50 & 478.6 & 2574 & $Y$ & PL \\
\hline Spratt 1 & 0 & 50 & 894.4 & 2141 & N & $\mathrm{PL}$ \\
\hline Spratt 2 & 0 & 50 & 894.4 & 2145 & $N$ & $\mathrm{PL}$ \\
\hline Spratt 2 & 0 & 50 & 894.4 & 2135 & Y & PL \\
\hline Spratt 2 & 0 & 53 & 233.2 & 2142 & $\mathbb{N}$ & PL \\
\hline Spratt 2 & 0 & 53 & 233.2 & 2143 & $N$ & PL \\
\hline Spratt 2 & 0 & 53 & 233.2 & 2165 & $N$ & $\mathrm{PL}$ \\
\hline Spratt 2 & 1 & 53 & 233.2 & 2135 & $\gamma$ & PL \\
\hline Spratt 2 & 1 & 53 & 233.2 & 2146 & Y & PL \\
\hline Spratt 2 & 1 & 53 & 233.2 & 2138 & $Y$ & PL \\
\hline Spratt 2 & 0 & 82 & 333.1 & 225 & $Y$ & PL \\
\hline 2nd Line s. of Roger Stevens & 1 & 82 & 333.1 & 202 & $N$ & PL \\
\hline 2nd Line s. of Roger Stevens & 1 & 82 & 333.1 & 236 & $N$ & PL \\
\hline 2nd Line s. of Roger Stevens & 2 & 82 & 333.1 & 241 & $N$ & PL \\
\hline
\end{tabular}


Appendix C cont...

\begin{tabular}{|c|c|c|c|c|c|c|}
\hline Location & $\begin{array}{c}\text { Road } \\
\text { Number }\end{array}$ & $\begin{array}{l}\text { Traffic } \\
\text { Volume }\end{array}$ & Distance $(m)$ & Tag & Return & Species \\
\hline 2nd Line s. of Roger Stevens & 0 & 83 & 638.4 & 200 & $N$ & $\mathrm{PL}$ \\
\hline 2nd Line s. of Roger Stevens & 0 & 83 & 638.4 & 204 & $\mathbb{N}$ & PL \\
\hline 2nd Line s. of Roger Stevens & 2 & 83 & 638.4 & 232 & $\mathbb{N}$ & PL \\
\hline 2nd Line s. of Roger Stevens & 2 & 83 & 638.4 & 239 & $\mathbb{N}$ & $\mathrm{PL}$ \\
\hline 2nd Line s. of Roger Stevens & 2 & 85 & 54.6 & 58 & N & TS \\
\hline 3rd Line s. of Bankfield Rd & 2 & 85 & 54.6 & 59 & N & $\mathrm{PL}$ \\
\hline 3rd Line s. of Bankfield Rd & 2 & 85 & 54.6 & 102 & $\mathbb{N}$ & PL \\
\hline 3rd Line s. of Bankfield Rd & 0 & 85 & 308.5 & 100 & $\gamma$ & $\mathrm{PL}$ \\
\hline 3rd Line s. of Bankfield Rd & 0 & 85 & 308.5 & 52 & $\gamma$ & TS \\
\hline 3rd Line s. of Bankfield Rd & 0 & 85 & 308.5 & 72 & Y & $\mathrm{PL}$ \\
\hline 3rd Line s. of Bankfield Rd & 2 & 85 & 308.5 & 114 & $N$ & PL \\
\hline 3rd Line s. of Bankfield Rd & 0 & 85 & 992.9 & 61 & $N$ & PL \\
\hline 3rd Line s. of Bankfield Rd & 0 & 85 & 992.9 & 62 & N & TS \\
\hline 3rd Line s. of Bankfield Rd & 0 & 85 & 992.9 & 111 & $N$ & $\mathrm{PL}$ \\
\hline 3rd Line s. of Bankfield Rd & 1 & 120 & 627.9 & 142 & $N$ & PL \\
\hline 4th Line $\mathrm{n}$. of Carsonby Rd & 2 & 120 & 627.9 & 135 & $\mathbb{N}$ & PL \\
\hline 4th Line $\mathrm{n}$. of Carsonby Rd & 2 & 122 & 60.8 & 2199 & $\mathbb{N}$ & TS \\
\hline 2nd Line $n$. of Phelan Rd & 2 & 122 & 60.8 & 2510 & $N$ & $\mathrm{PL}$ \\
\hline 2nd Line $n$. of Phelan Rd & 0 & 151 & 984.1 & 69 & $\gamma$ & $P L$ \\
\hline 3rd Line s. of Carsonby Rd & 1 & 151 & 984.1 & 68 & $N$ & TS \\
\hline 3rd Line s. of Carsonby Rd & 1 & 151 & 984.1 & 116 & $N$ & PL \\
\hline 3rd Line s. of Carsonby Rd & 0 & 153 & 484.4 & 2167 & $N$ & $\mathrm{PL}$ \\
\hline 2nd Line $n$. of Phelan Rd & 1 & 153 & 484.4 & 2505 & $\mathbb{N}$ & TS \\
\hline 2nd Line $n$. of Phelan Rd & 2 & 153 & 484.4 & 2171 & Y & TS \\
\hline 2nd Line $n$. of Phelan Rd & 2 & 153 & 484.4 & 2192 & Y & $\mathrm{PL}$ \\
\hline 2nd Line n. of Phelan Rd & 0 & 168 & 41.8 & 217 & N & TS \\
\hline 2nd Line s. of Hwy 72 & 0 & 168 & 41.8 & 218 & $\mathrm{~N}$ & PL \\
\hline 2nd Line s. of Hwy 72 & 0 & 168 & 41.8 & 228 & Y & PL \\
\hline 2nd Line s. of Hwy 72 & 1 & 168 & 141.4 & 212 & $Y$ & TS \\
\hline 2nd Line s. of Hwy 72 & 1 & 168 & 141.4 & 214 & $Y$ & $\mathrm{PL}$ \\
\hline 2nd Line s. of Hwy 72 & 1 & 168 & 141.4 & 220 & $Y$ & $\mathrm{PL}$ \\
\hline 2nd Line s. of Hwy 72 & 2 & 168 & 141.4 & 235 & $N$ & $\mathrm{PL}$ \\
\hline 2nd Line s. of Hwy 72 & 1 & 182 & 17.9 & 155 & $\mathbb{N}$ & PL \\
\hline 3rd Line n. of Hwy 72 & 1 & 182 & 17.9 & 161 & $\mathbb{N}$ & $\mathrm{PL}$ \\
\hline 3rd Line $n$. of Hwy 72 & 1 & 182 & 17.9 & 197 & $\mathbb{N}$ & $\mathrm{PL}$ \\
\hline 3rd Line $n$. of Hwy 72 & 1 & 182 & 17.9 & 182 & Y & TS \\
\hline 3rd Line n. of Hwy 72 & 1 & 182 & 48.7 & 2177 & $\mathbb{N}$ & TS \\
\hline 3rd Line s. of Roger Stevens Rd & 1 & 182 & 48.7 & 2181 & $\mathbb{N}$ & TS \\
\hline 3rd Line s. of Roger Stevens Rd & 1 & 182 & 48.7 & 2197 & $\mathbb{N}$ & PL \\
\hline 3rd Line s. of Roger Stevens Rd & 1 & 182 & 48.7 & 2508 & $\mathbb{N}$ & TS \\
\hline 3rd Line s. of Roger Stevens Rd & 1 & 182 & 48.7 & 2518 & $\mathbb{N}$ & PL \\
\hline 3rd Line s. of Roger Stevens Rd & 1 & 182 & 48.7 & 2179 & $Y$ & PL \\
\hline 3rd Line s. of Roger Stevens Rd & 1 & 182 & 48.7 & 2196 & Y & TS \\
\hline 3rd Line s. of Roger Stevens Rd & 1 & 182 & 48.7 & 2189 & Y & PL \\
\hline 3rd Line s. of Roger Stevens Rd & 1 & 182 & 48.7 & 2186 & $\gamma$ & TS \\
\hline 3rd Line s. of Roger Stevens Rd & 0 & 182 & 422.9 & 2183 & N & $\mathrm{PL}$ \\
\hline
\end{tabular}


Appendix C cont...

\begin{tabular}{|c|c|c|c|c|c|c|}
\hline Location & $\begin{array}{c}\text { Road } \\
\text { Number }\end{array}$ & $\begin{array}{l}\text { Traffic } \\
\text { Volume }\end{array}$ & Distance $(m)$ & Tag & Return & Species \\
\hline 3rd Line s. of Roger Stevens Rd & 0 & 182 & 422.9 & 2185 & $N$ & PL \\
\hline 3rd Line s. of Roger Stevens Rd & 0 & 182 & 422.9 & 2517 & N & TS \\
\hline 3rd Line s. of Roger Stevens Rd & 0 & 182 & 422.9 & 2187 & Y & TS \\
\hline 3rd Line S. of Roger Stevens Rd & 1 & 182 & 422.9 & 2178 & N & TS \\
\hline 3rd Line s. of Roger Stevens Rd & 1 & 182 & 422.9 & 2193 & $\mathbb{N}$ & PL \\
\hline 3rd Line s. of Roger Stevens Rd & 1 & 182 & 422.9 & 2198 & N & TS \\
\hline 3rd Line s. of Roger Stevens Rd & 0 & 192 & 10.4 & 159 & $\gamma$ & PL \\
\hline 3rd Line $n$. of Hwy 72 & 1 & 192 & 10.4 & 181 & N & PL \\
\hline 3rd Line $n$. of Hwy 72 & 1 & 216 & 584.6 & 174 & $N$ & $\mathrm{PL}$ \\
\hline McCordick Road & 1 & 216 & 584.6 & 185 & $N$ & $P L$ \\
\hline McCordick Road & 1 & 216 & 584.6 & 196 & $N$ & PL \\
\hline McCordick Road & 2 & 216 & 584.6 & 172 & $N$ & TS \\
\hline McCordick Road & 0 & 298 & 10.4 & 2535 & Y & $\mathrm{PL}$ \\
\hline Blanchfield Rd & 1 & 298 & 10.4 & 2556 & $N$ & TS \\
\hline Blanchfield Rd & 1 & 298 & 10.4 & 2543 & Y & TS \\
\hline Blanchfield Rd & 1 & 298 & 10.4 & 2561 & Y & TS \\
\hline Blanchfield Rd & 1 & 298 & 53.2 & 2544 & $N$ & TS \\
\hline Blanchfield Rd & 1 & 298 & 53.2 & 2557 & N & TS \\
\hline Blanchfield Rd & 1 & 365 & 10.4 & 2575 & Y & PL \\
\hline Mohr's Road & 1 & 365 & 10.4 & 2588 & Y & PL \\
\hline Mohr's Road & 0 & 614 & 235.6 & 2149 & Y & TS \\
\hline Airport & 0 & 614 & 235.6 & 2151 & $Y$ & PL \\
\hline Airport & 0 & 614 & 235.6 & 2157 & Y & TS \\
\hline Airport & 1 & 614 & 235.6 & 2162 & $\mathbb{N}$ & TS \\
\hline Airport & 1 & 688 & 494.7 & 23 & $N$ & PL \\
\hline 3rd Line s. of Carsonby Rd & 1 & 688 & 494.7 & 117 & $N$ & PL \\
\hline 3rd Line s. of Carsonby Rd & 1 & 874 & 112.7 & 2150 & $N$ & TS \\
\hline Airport & 1 & 874 & 112.7 & 2158 & $N$ & TS \\
\hline Airport & 1 & 874 & 112.7 & 2163 & $N$ & TS \\
\hline Airport & 1 & 903 & 314.9 & 2589 & N & TS \\
\hline Airport & 1 & 903 & 314.9 & 2592 & N & $\mathrm{PL}$ \\
\hline John Shaw Road & 1 & 903 & 314.9 & 2596 & $\mathrm{~N}$ & $\mathrm{PL}$ \\
\hline John Shaw Road & 1 & 1047 & 474.1 & 267 & $\gamma$ & PL \\
\hline John Shaw Road & 2 & 1047 & 474.1 & 243 & $\mathbb{N}$ & PL \\
\hline Jake Street, Osgoode & 2 & 1047 & 474.1 & 247 & $N$ & PL \\
\hline Jake Street, Osgoode & 2 & 1047 & 474.1 & 261 & $N$ & TS \\
\hline Jake Street, Osgoode & 2 & 1047 & 474.1 & 273 & N & PL \\
\hline Jake Street, Osgoode & 0 & 1047 & 671.2 & 268 & $\mathbb{N}$ & $\mathrm{PL}$ \\
\hline Jake Street, Osgoode & 0 & 1047 & 671.2 & 272 & N & TS \\
\hline Jake Street, Osgoode & 0 & 1047 & 671.2 & 284 & N & $P L$ \\
\hline Jake Street, Osgoode & 1 & 1047 & 671.2 & 244 & N & PL \\
\hline Jake Street, Osgoode & 1 & 1047 & 671.2 & 248 & $\mathbb{N}$ & $\mathrm{PL}$ \\
\hline Jake Street, Osgoode & 1 & 1047 & 671.2 & 264 & $N$ & TS \\
\hline Jake Street, Osgoode & 2 & 1107 & 224.9 & 2581 & $N$ & $P L$ \\
\hline Jake Street, Osgoode & 2 & 1107 & 224.9 & 2584 & $N$ & TS \\
\hline John Shaw Road & 2 & 1107 & 224.9 & 2595 & $\mathbb{N}$ & PL \\
\hline
\end{tabular}


Appendix $\mathrm{C}$ cont...

\begin{tabular}{|c|c|c|c|c|c|c|}
\hline Location & $\begin{array}{c}\text { Road } \\
\text { Number }\end{array}$ & $\begin{array}{c}\text { Traffic } \\
\text { Volume } \\
\end{array}$ & Distance $(\mathrm{m})$ & Tag & Return & Species \\
\hline John Shaw Road & 2 & 1107 & 224.9 & 95 & $\mathrm{~N}$ & TS \\
\hline John Shaw Road & 0 & 1498 & 175.8 & 253 & $\mathbb{N}$ & $P L$ \\
\hline John Shaw Road & 0 & 1498 & 175.8 & 257 & Y & PL \\
\hline 2nd Line at Dalmeny Road & 1 & 1498 & 175.8 & 280 & N & TS \\
\hline 2nd Line at Dalmeny Road & 0 & 2024 & 2.375 & 121 & $Y$ & TS \\
\hline 2nd Line at Dalmeny Road & 1 & 2024 & 2.375 & 122 & $N$ & PL \\
\hline 4th Line $\mathrm{n}$. of Carsonby Rd & 1 & 2024 & 15.4 & 138 & $N$ & PL \\
\hline 4th Line $\mathrm{n}$. of Carsonby Rd & 1 & 2024 & 194.7 & 149 & $N$ & TS \\
\hline 4th Line $\mathrm{n}$. of Carsonby Rd & 2 & 2024 & 194.7 & 126 & $N$ & TS \\
\hline 4th Line $\mathrm{n}$. of Carsonby Rd & 2 & 2024 & 194.7 & 147 & $N$ & $\mathrm{PL}$ \\
\hline 4th Line s. of Carsonby Rd & 0 & 2024 & 353.8 & 139 & N & $P L$ \\
\hline 4th Line s. of Carsonby Rd & 0 & 2024 & 353.8 & 154 & N & PL \\
\hline 4th Line s. of Carsonby Rd & 0 & 2024 & 353.8 & 127 & N & PL \\
\hline 4th Line s. of Carsonby Rd & 0 & 2024 & 353.8 & 129 & N & TS \\
\hline 4th Line s. of Carsonby Rd & 0 & 2024 & 353.8 & 133 & $N$ & PL \\
\hline 4th Line s. of Carsonby Rd & 0 & 2024 & 353.8 & 145 & N & PL \\
\hline Limebank at Highschool & 1 & 2047 & 694.6 & 2567 & $N$ & $\mathrm{PL}$ \\
\hline Limebank at Highschool & 1 & 2047 & 694.6 & 2573 & $N$ & PL \\
\hline 4th Line $n$. of Carsonby Rd & 1 & 2144 & 1212 & 134 & $N$ & PL \\
\hline 4th Line s. of Carsonby Rd & 1 & 2203 & 707.5 & 137 & $\mathbb{N}$ & PL \\
\hline 4th Line s. of Carsonby Rd & 1 & 2203 & 707.5 & 153 & $\mathbb{N}$ & PL \\
\hline 4th Line s. of Carsonby Rd & 1 & 2203 & 707.5 & 131 & $\mathbb{N}$ & PL \\
\hline 4th Line s. of Carsonby Rd & 1 & 2203 & 707.5 & 141 & $\mathbb{N}$ & $\mathrm{PL}$ \\
\hline Cabin Rd & 1 & 3077 & 721.7 & 2521 & $N$ & PL \\
\hline Cabin Rd & 1 & 3077 & 721.7 & 2526 & $N$ & TS \\
\hline Cabin $\mathrm{Rd}$ & 1 & 3077 & 721.7 & 2532 & $N$ & PL \\
\hline Cabin Rd & 1 & 3077 & 721.7 & 2536 & $N$ & TS \\
\hline Cabin Rd & 1 & 3077 & 721.7 & 2540 & N & TS \\
\hline Cabin Rd & 1 & 3077 & 721.7 & 2548 & N & TS \\
\hline Cabin Rd & 1 & 3077 & 721.7 & 2554 & $\mathbf{N}$ & PL \\
\hline Moodie & 1 & 3078 & 50 & 641 & $\mathbb{N}$ & TS \\
\hline Moodie & 1 & 3078 & 50 & 644 & $\mathbb{N}$ & TS \\
\hline Moodie & 1 & 3078 & 50 & 647 & $\mathbb{N}$ & TS \\
\hline Moodie & 1 & 3078 & 50 & 648 & $N$ & TS \\
\hline Moodie & 1 & 3078 & 50 & 865 & $\mathbb{N}$ & $P L$ \\
\hline Moodie & 1 & 3078 & 50 & 895 & $\mathbb{N}$ & $\mathrm{PL}$ \\
\hline Moodie & 1 & 3078 & 50 & 924 & $N$ & TS \\
\hline Moodie & 1 & 3078 & 50 & 641 & Y & TS \\
\hline Moodie & 1 & 3078 & 50 & 648 & $Y$ & TS \\
\hline Moodie & 1 & 3078 & 50 & 865 & $Y$ & PL \\
\hline Moodie & 1 & 3078 & 50 & 865 & $Y$ & PL \\
\hline 2nd Line at Dalmeny Road & 2 & 3181 & 660.6 & 249 & $\mathbb{N}$ & $P L$ \\
\hline 2nd Line at Dalmeny Road & 2 & 3181 & 660.6 & 254 & $\mathbb{N}$ & PL \\
\hline 2nd Line at Dalmeny Road & 2 & 3181 & 660.6 & 275 & $\mathbb{N}$ & TS \\
\hline 2nd Line at Dalmeny Road & 2 & 3181 & 660.6 & 283 & $\mathbb{N}$ & TS \\
\hline 2nd Line at Dalmeny Road & 2 & 3181 & 660.6 & 286 & $\mathbb{N}$ & $\mathrm{PL}$ \\
\hline
\end{tabular}


Appendix C cont...

\begin{tabular}{|c|c|c|c|c|c|c|}
\hline Location & $\begin{array}{c}\text { Road } \\
\text { Number }\end{array}$ & $\begin{array}{l}\text { Traffic } \\
\text { Volume } \\
\end{array}$ & Distance (m) & Tag & Return & Species \\
\hline Cabin Rd & 0 & 4300 & 798.9 & 2523 & $\mathrm{~N}$ & $\mathrm{PL}$ \\
\hline Cabin Rd & 0 & 4300 & 798.9 & 2528 & $N$ & TS \\
\hline Cabin Rd & 1 & 4300 & 798.9 & 2538 & $\mathbb{N}$ & PL \\
\hline Cabin Rd & 1 & 4300 & 798.9 & 2539 & $N$ & TS \\
\hline Cabin Rd & 1 & 4300 & 798.9 & 2545 & $\mathbb{N}$ & TS \\
\hline Cabin Rd & 1 & 4300 & 798.9 & 2552 & $N$ & TS \\
\hline Cabin $\mathrm{Rd}$ & 0 & 4300 & 926.7 & 2541 & $N$ & TS \\
\hline Cabin $\mathrm{Rd}$ & 0 & 4300 & 926.7 & 2549 & N & TS \\
\hline Cabin Rd & 0 & 4300 & 926.7 & 2555 & $N$ & PL \\
\hline Cabin Rd & 2 & 4300 & 926.7 & 2524 & N & $\mathrm{PL}$ \\
\hline Cabin Rd & 2 & 4300 & 926.7 & 2527 & $N$ & TS \\
\hline Cabin Rd & 2 & 4300 & 926.7 & 2530 & $N$ & TS \\
\hline Cabin Rd & 2 & 4300 & 969.7 & 2522 & N & $\mathrm{PL}$ \\
\hline Limebank at Highschool & 1 & 6837 & 105.1 & 2562 & $\mathbb{N}$ & PL \\
\hline Limebank at Highschool & 1 & 6837 & 105.1 & 2568 & $N$ & PL \\
\hline Lester & 1 & 8254 & 30 & 2973 & $Y$ & PL \\
\hline Lester & 1 & 8254 & 40 & 1434 & $\mathbb{N}$ & PL \\
\hline Lester & 1 & 8254 & 40 & 2965 & $N$ & PL \\
\hline Lester & 1 & 8254 & 50 & 2963 & $\mathbb{N}$ & PL \\
\hline Lester & 1 & 8254 & 60 & 2964 & Y & TS \\
\hline Lester & 1 & 8254 & 60 & 2970 & $Y$ & TS \\
\hline Lester & 1 & 8254 & 90 & 2968 & $N$ & TS \\
\hline Lester & 1 & 8254 & 100 & 3976 & $N$ & PL \\
\hline Lester & 1 & 8254 & 100 & 2973 & Y & $\mathrm{PL}$ \\
\hline Highway 7 & 1 & 10300 & 30 & 2912 & N & $\mathrm{PL}$ \\
\hline Highway 7 & 1 & 10300 & 50 & 2674 & $\gamma$ & PL \\
\hline Highway 7 & 1 & 10300 & 75 & 2672 & $\gamma$ & $\mathrm{PL}$ \\
\hline Highway 7 & 1 & 10300 & 100 & 2711 & N & PL \\
\hline Highway 7 & 1 & 10300 & 150 & 2913 & N & $\mathrm{PL}$ \\
\hline 2nd Line s. of Hwy 72 & 2 & 12005 & 543 & 215 & N & PL \\
\hline 2nd Line s. of Hwy 72 & 2 & 12005 & 543 & 216 & $N$ & TS \\
\hline 2nd Line s. of Hwy 72 & 2 & 12005 & 543 & 221 & $N$ & PL \\
\hline 2nd Line s. of Hwy 72 & 2 & 12005 & 543 & 242 & $N$ & $\mathrm{PL}$ \\
\hline West Hunt Club & 1 & 13423 & 60 & 845 & $N$ & $P L$ \\
\hline West Hunt Club & 1 & 13423 & 60 & 846 & $\mathrm{~N}$ & PL \\
\hline West Hunt Club & 1 & 13423 & 60 & 847 & $N$ & TS \\
\hline West Hunt Club & 1 & 13423 & 60 & 848 & N & TS \\
\hline 2nd Line $n$. of Phelan Rd & 1 & 15035 & 10.4 & 2166 & N & PL \\
\hline 2nd Line $n$. of Phelan Rd & 1 & 15035 & 10.4 & 2191 & N & TS \\
\hline 2nd Line $n$. of Phelan Rd & 1 & 15035 & 10.4 & 2509 & N & $\mathrm{PL}$ \\
\hline
\end{tabular}


Appendix D. Sample alata manipulation for mean heading.

Mean Bearing: Direction of movement.

Example Path - the road was always zeroed so the heading read North-South long the lenth of the road.

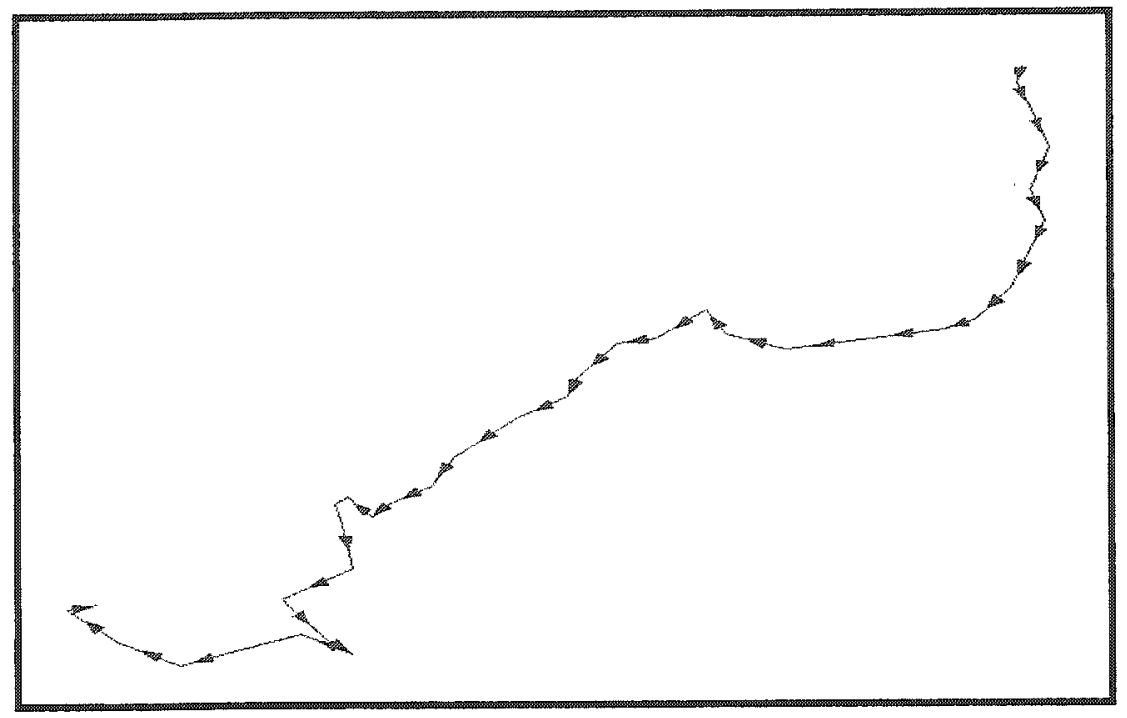

\begin{tabular}{ccc}
\hline $\begin{array}{c}\text { Heading }\left({ }^{\circ}\right) \\
\text { from North }\end{array}$ & Cos $\phi$ & Sin $\phi$ \\
\hline 180 & -1.000 & 0.000 \\
190 & -0.985 & -0.174 \\
160 & -0.940 & 0.342 \\
160 & -0.940 & 0.342 \\
200 & -0.940 & -0.342 \\
160 & -0.940 & 0.342 \\
200 & -0.940 & -0.342 \\
200 & -0.940 & -0.342 \\
220 & -0.766 & -0.643 \\
250 & -0.342 & -0.940 \\
260 & -0.174 & -0.985 \\
$\cdot$ & - &. \\
& - & - \\
300 & 0.500 & -0.866 \\
250 & -0.342 & -0.940 \\
300 & 0.500 & -0.866 \\
310 & 0.643 & -0.766 \\
10 & 0.985 & 0.174 \\
\hline
\end{tabular}


Appendix $\mathbb{E}$ continued...

Each angle was represented by an $x, y$ coordinate in a Cartesian plane. Mean bearing was calculated by taking the inverse of tan of the sum of $y$ values divided by the sum of $x$ values.

$\mathrm{x}^{\prime}=\left(\cos \phi_{1}+\cos \phi_{2}+\ldots+\cos \phi_{\mathrm{n}}\right)$

$x^{\prime}=(-15.092)$

$y^{\prime}=\left(\sin \phi_{1}+\sin \phi_{2}+\ldots+\sin \phi_{n}\right)$

$y^{\prime}=(-15.156)$

When $x^{\prime}$ is greater than 0 :

When $x^{\prime}$ is less than 0 :

Mean bearing $=\arctan \left(y^{\prime} / x^{\prime}\right)$

$$
\text { Mean Bearing }=180+\arctan \left(y^{\prime} / x^{\prime}\right)
$$

Therefore, the mean bearing of the example path is:

Mean Bearing $=180+(-15.156 /-15.092)$

Mean Bearing $=225^{\circ}$ 